DEPARTMENT OF THE INTERIOR

UNITED STATES GEOLOGTCAL SURVEY

GEORGE OTIS SMITH, DHECTOR

TWENTY-EIGHTH ANNUAL REPORT

OF THE

\title{
DIRECTOR OF THE UNITED STATES GEOLOGICAL SURVEY
}

TO THE

\section{SECRETARY OF THE INTERIOR}

FOR THE FISCAL YEAR

ENDED JUNE 30

1907

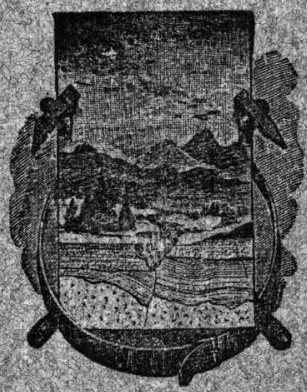

WASIINGTON

GOVERNMENT PRINTING OFPICA 
DEPARTMENT OF THE INTERIOR

UNITED STATES GEOLOGICAL SURVEY

GEORGE OTIS SMITH, DIRECTOR

\section{TWENTY-EIGHTH ANNUAL REPORT}

OF THE

\section{DIRECTOR OF THE UNITED STATES GEOLOGICAL SURVEI}

TO THE

\section{SECRETARY OF THE INTERIOR}

FOR THE FISCAL YEAR

ENDED JUNE 30

$$
1907
$$

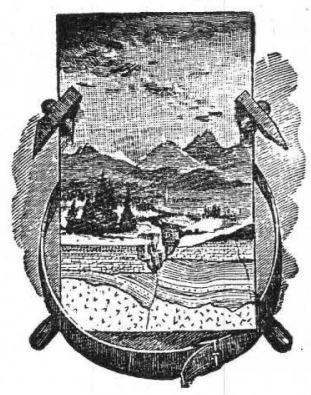

WASHINGTON 



\section{CONTENTS.}

Introduction Page.

Organization

Special features of the work 3

Work of the year

Field and office work by the Director

Geologic branch

Administration _._.

Publications _.- 7

Division of geology and paleontology

Organization - 7 .

Personnel _. -

Classification of work

Allotments of funds

Geologic work in Eastern and Southeastern States__- 10

Geologic work in Central States east of $97^{\circ}$

Geologic work in the 16 Western public-land States and

Territories -

General geologic work

Division of Alaskan mineral resources

Personnel _. - 22

Field operations in season of 1906

Geographic distribution of investigations _______ 23

Field operations in season of 1907

Division of mining and mineral resources_________-___-__-_ $\quad 26$

Division of chemical and physical research___________ 27

Topographic branch _._-_-_- 29

Organization _.

Personnel _ _.

Summary of results_-_-_- 30

Eastern division _._. 31

Field work _.__ 31

Summary - - 31

Details of work by States____ 32

Drainage surveys in Minnesota

Office work _- 39

Western division

Field work _. 39

Summary _ _- 39

Details of work by States___________ 40

Office work _-_ 44

Triangulation and computing section

Field work _-_ 45

Eastern division _._. 45

Western division 
Work of the year-Continued.

Topographic branch-Continued.

Triangulation and computing section-Continued.

Office work

Page.

Eastern division

Western division

Section of inspection of surveying and mapping $\quad 52$

Section of instruments and records

Division of geography and forestry 53

Credit for suggestions

Water-resources branch __- 54

Administration

Stream-flow measurements ___ 55

Underground-water investigations _____________ 58

Investigations of quality of water-_a_- 59

Technologic branch _._. 61

Organization _

Fuel division _. 61

Chemical section _. 61

Steam-engineering section _._____________-_ 62

Gas-producer section _._- 63

Inspection and smoke-abatement section__________ 63

Coking and washery sections

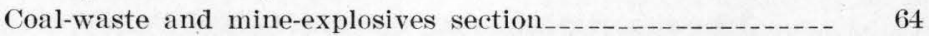

Briquette section _-__-_-_-_- 64

Mining and coal-sampling section____ 65

Structural-materials division ___ 65

Publication branch

Editorial division

Section of texts

Section of geologic maps_____ 67

Section of topographic maps_._- 68

Section of distribution

Division of engraving and printing

Instrument shop

Section of graphic illustrations_____- 70

Photographic laboratory _._- 71

Administrative branch _____ 71

Executive division _._._._._. 71

Section of correspondence, records, etc

Division of disbursements and accounts

Library -

Index

\section{ILLUSTRATION.}

PL. I. Map of United States, showing areas covered by topographic surveys_ 


\title{
TWENTY-EIGHTH ANNUAL REPORT OF THE DIRECTOR OF THE UNITED STATES GEOLOGICAL SURVEY.
}

\author{
George Otis Sмith, Director.
}

\section{INTRODUCTION.}

The plan of operations for the last fiscal year, including an itemized statement of the appropriations, amounting to $\$ 1,758,720$, with the allotments thereof, was approved by the Secretary of the Interior on July 10, 1906. The work of the various branches and divisions conformed to this plan, and a detailed statement of their operations may be found on later pages.

On January 23 the former Director, Charles D. Walcott, was appointed to the position of Secretary of the Smithsonian Institution, and his resignation as Director was accepted by the President, becoming effective April 30, 1907. Mr. Walcott has been a member of the Survey since its organization, and the thirteen years of his service as the administrative head of the bureau cover the period of its greatest growth.

At the beginning of his directorship Mr. Walcott disclaimed any desire to make radical changes in either the policy or the administration of the Survey as developed under his predecessors, King and Powell, but in his first report, the Director's sixteenth, he mentioned certain readjustments which he deemed desirable in order that the Survey might better meet the economic and educational needs of the country. It is noteworthy that, almost without exception, these improvements have been accomplished, and even more fully than as then outlined. Among these changes may be mentioned: The raising of the standard of the topographic maps, with the representation thereon of land subdivision lines, and the extension of exact leveling and primary triangulation; the placing of the entire topographic and

geologic force within the classified service; the obtaining of authority from Congress to issue separates of the annual report in pamphlet form, thus permitting advance publication of chapters of the Mineral Resources report, as well as of papers on economic geology; the 
enlargement of the work of the divisions of hydrography, mineral resources, and geology, in the last case providing for reconnaissance surveys of regions of economic importance.

Equally notable was the growth of the Survey under Mr. Walcott's administration, as shown by the increase in both the extent and the scope of its operations. The appropriations for the last fiscal year amounted to more than four times the total of those made thirteen years ago, and there was, of course, a corresponding increase in the amount of field and office work performed. The development of the relations between the Geological Survey and the public within the same period is measured by a more than fourfold increase in amount of official correspondence, nearly fourfold increase in number of printed pages in the various reports of the year, and a more than fivefold increase in copies of maps printed, while the total annual distribution of publications, books, and maps grew from less than 200,000 to nearly a million copies, the sales increasing from $\$ 2,100$ to over $\$ 18,000$. The extent to which the results of the work by this organization are now utilized by both the industrial world and the educational and scientific institutions furnishes the best index of the degree of success attained by $\mathrm{Mr}$. Walcott and his colleagues.

\section{ORGANIZATION.}

The organization of the Survey was modified within the year by the creation of a technologic branch, by changes in the divisions constituting the topographic branch, and by the substitution of the name water-resources branch for hydrographic branch. As now organized the branches and divisions of the Geological Survey are as follows:

Branch.

Division.

$\begin{aligned} \text { Geologic_epographic_. } & \left\{\begin{array}{l}\text { Geology and paleontology. } \\ \text { Alaskan mineral resources. } \\ \text { Mining and mineral resources. } \\ \text { Chemical and physical research. }\end{array}\right. \\ \text { Water resources } & \begin{array}{l}\text { Atlantic. } \\ \text { Central. } \\ \text { Rocky Mountain. } \\ \text { Pacific. }\end{array} \\ & \begin{array}{l}\text { River-flow measurements. } \\ \text { Ground-water investigations. } \\ \text { Quality of water investigations. } \\ \text { Debris investigations. }\end{array}\end{aligned}$

Technologic

$\{$ Fuels.

tural materials.

Publication

Pook editing and distribution.

Map editing.

Engraving and printing.

Executive.

Administrative

$\left\{\begin{array}{l}\text { Disbursements and accounts. } \\ \text { Library. }\end{array}\right.$ 
The period of intimate connection between the Reclamation Service and the Geological Survey that had begun with the organization of this reclamation work as a separate division of the hydrographic branch of the Survey was terminated in March by acceptance of the resignation of Mr. Walcott as Director of the Reclamation Service. His successor, Frederick H. Newell, had been chief engineer of the Reclamation Service, and earlier chief hydrographer of the Survey, and he still retains connection with the Survey as a consulting engineer in the water-resources branch.

On April 4 the Secretary of the Interior changed the title of the administrative head of the geologic branch from geologist in charge of geology to chief geologist.

The reorganization of the topographic branch, on March 19, provided for five divisions in place of two, and on April 6 this plan was further modified by the consolidation of the northeastern and southeastern divisions into the Atlantic division. The four divisions thus formed correspond in name with the four geographic sections created in 1904 and later united into the two divisions. This reversion to the smaller administrative unit appears to be necessitated by the increase in the amount of work done in the topographic branch. The chiefs of these four divisions constitute a topographic committee, with the Director as chairman. Another important feature in the plan of reorganization was the formation of a section of inspection, three of the most experienced topographers being selected to serve as inspectors of topographic work.

The change from hydrographic to water resources in the name of that branch was made because the former did not correctly define the character of the work performed. The investigations are authorized by appropriations in successive sundry civil bills " for gaging the streams and determining the water supply of the United States and for the investigation of underground currents and artesian wells and the preparation of reports upon the best methods of utilizing the water resources."

On April 2 the Secretary of the Interior approved the Director's organization of the work progressing under the two appropriations for testing fuels and structural materials into the technologic branch, with two divisions corresponding to the two appropriations.

\section{SPECIAL FEATURES OF THE WORK.}

Cooperation of States.-Many of the States have continued the policy of cooperation with the National Survey, and the details of this cooperative work in geology, topography, and investigation of water resources are given on later pages of this report. On May 20-21 a conference was held between the representatives of 17 State survey organizations and the administrative heads of the various 
divisions of the Federal Survey. Current plans were discussed with a view to preventing possible duplication of work and to assure the fullest cooperation. This meeting was the outcome of an earlier conference of official geologists at New York in December, at which Director Walcott proposed the better coordination of the work of the State and Federal surveys.

General map of United States.-In recognition of the demand for general, as well as detailed, maps of the United States, plans have been perfected for the preparation of a map on a scale appropriate for a general map. The scale adopted by international agreement for a general map of the world is $1: 1,000,000$, or about 16 miles to the inch, and this appears well adapted to the present need. The proposed map will comprise 52 sheets, each one of which includes 4 degrees of latitude and 6 degrees of longitude. It will be employed primarily by the Survey as a base for a general geologic map of the United States, but the base will be designed with a view to all the manifold uses which Federal and State officials and the people have for a general map.

Surveys of coal lands.-Special investigations were conducted last year to determine the extent of the coal lands remaining in the possession of the Government and the quality and value of the coal deposits on these public lands. This work will be continued on a larger scale and under a more comprehensive plan. S Special attention will be given to the classification and valuation of the coal lands and their prompt segregation from the noncoal lands. This work is to be provided for by a joint allotment from the appropriations for geologic and topographic surveys and that for testing coals belonging to the Government, and the General Land Office is also cooperating. The field operations were started before the close of the fiscal year.

Resignation of geologists.-The geologic branch of the Survey is experiencing embarrassment by its success as a training school for mining geologists. The increasing exodus of such geologists by reason of their employment by large mining companies at salaries much greater than those paid them by the Government seriously impairs the efficiency of the economic work of the Survey. During the last year the Survey has lost the services of seven geologists in this way.

Alaskan surveys.-The progress of areal surveys in Alaska is given in detail on later pages of this report, and it is pointed out that practically every mining camp has been visited and investigated. The importance of the rapid extension of such surveys can not be too strongly emphasized, for they furnish not only a guide to the prospector but are absolutely essential to all engineering enterprises. It is worthy of note that while nearly half a million dollars has been 
spent on Alaskan surveys and investigations, this is only about onehalf of 1 per cent of the output of gold in the areas benefited by these surveys.

Tenth International Geological Congress.-The Geological Survey was represented at the Tenth International Geological Congress, held in Mexico in September, by a committee of delegates composed of Messrs. Emmons, Chamberlin, Hayes, Lindgren, Ransome, and Smith. Many courtesies were extended to the congress by the Government and the Geological Survey of Mexico, whereby its work was greatly facilitated. Conferences were held with the leading geologists of foreign countries relating to questions of correlation and other matters of general interest to geologists and geological surveys throughout the world. The most important result of the congress was to secure a larger degree of cooperation and coordination between this and other government surveys.

Water-resources work.-The ultimate purposes of the work relating to the water resources are Federal in character, the data so far collected being in the nature of a census of water-supply resources; and although there are various private uses to which they must necessarily have been put, the benefits to the Federal Government have been worth many times the amount invested in the work. For example, the United States is now expending more than $\$ 40,000,000$ for the construction of irrigation works, the integrity of which rests upon the amount of water available for distribution from these systems. That it was possible for the United States to proceed to almost immediate construction of the reclamation projects is due to the fact that throughout the arid West the United States Geological Survey had for years previous collected records of stream flow, and a consultation of these records enabled the officers in charge of the reclamation work to determine at once which projects would and which would not be feasible. More recently, under an Executive order, $\bullet$ a commission has been appointed, known as the Inland Waterways Commission, the purpose of which is to investigate and determine upon the broad policies to be followed by the Government with reference to the interstate rivers which make up the water highways under the control of the Federal Government. Almost immediately upon commencing its work this commission found it necessary to make use of the results of water-supply investigations that had previously been made by the Survey, and the work of the commission has been facilitated thereby.

Stream-flow measurements are needed in the South Atlantic States to secure a knowledge of the water resources, upon the utilization of which the industrial development must largely depend.

Reorganization of publication branch.-The reorganization of the publication branch, by placing under one head all work done in con- 
nection with the printing of reports, is expected to secure more effective administration with the same personnel. The importance of expediting the publication of the various reports issued by the Survey is realized, and plans are being perfected which it is hoped will remove some of the causes of delay. In this endeavor the Public Printer is extending hearty cooperation.

Changes in business methods.--Some changes in business methods have been made. These were necessitated both by the increase in the operations of the Bureau and by the demands made upon the Survey by the public. Such reforms have as their purpose expeditious action upon all financial transactions, with the least possible deviation from commercial practice; prompt and adequate action upon all correspondence with the public; and sufficient announcement of the Survey's current publications by means of press notices and official circulars.

\section{WORK OF THE YEAR.}

\section{FIELD AND OFFICE WORK BY THE DIRECTOR.}

During the months of August and September, 1906, the former Director studied in detail the Cambrian section of the Wasatch Mountains in northern Utah and southern Idaho and made large collections of fossils from various horizons in the section. After the 15th of October he proceeded to Nevada, California, Oregon, and North Dakota in connection with administrative matters relating to the work of the Reclamation Service.

During the spring and fall of 1906 and the winter of $1906-7$ all his available time was given to the preparation of Monograph LI of the Survey and the writing out of field notes.

\section{GEOLOGIC BRANCH.}

\section{ADMINISTRATION.}

The geologic branch comprises four divisions, viz: (1) Geology and paleontology, (2) Alaskan mineral resources, (3) mining and mineral resources, and (4) chemical and physical researches. The chief of each division is responsible for the details of its administration, and the supervision of the chief geologist is required merely for the purpose of securing proper cooperation between the several divisions and coordination of the various lines of work. It has been found advantageous in many cases to employ the members of one division in the work of other divisions, and the form of organization permits ready transfer to meet most exigencies as they arise. This is especially desirable between the divisions of geology and mineral resources, and the geologists who have acquired special familiarity 
with certain classes of mineral deposits prepare the chapters on these deposits for the annual statistical volume on the mineral resources of the United States.

\section{PUBLICATIONS.}

The official publications of the geologic branch during the year included 14 geologic folios, 1 monograph, 6 professional papers, 26 bulletins, and the annual volume on mineral resources. Among the bulletins was the annual volume, "Contributions to Economic Geology," for 1906. Part I (Bulletin 315), containing 46 papers by 32 authors.

These publications embody the economic results and the principal contributions to science derived from the various investigations. In addition there were published, with the permission of the Director, in scientific journals and the transactions of scientific societies, a large number of papers based on work carried on by members of the geologic branch. It is the policy of the Survey to encourage such outside publication, which is ordinarily a restatement in more technical form of results and conclusions contained in reports already issued or in press. In some cases, also, original material obtained incidentally in connection with Survey work, but not appropriate for official reports, has been issued through unofficial publications. In no case has a member of the Survey received compensation for such material.

DIVISION OF GEOLOGY AND PALEONTOLOGY.

ORGANIZATION.

A few minor changes have been made in the organization of this division during the year. The most important, made toward the end of the year, were the increase in administrative responsibility placed upon the geologists in charge of the section of metalliferous deposits and the section of economic geology of fuels. This change was made primarily in the interest of more efficient administration and in recognition of conditions arising from the normal development of the organization, and also to relieve the geologist in charge of the division of some administrative details. It will probably be found desirable to further recognize this development in future by increasing the administrative responsibility of other section chiefs. Owing to changes in the personnel of the division, the positions of chief of the sections of petrology, economic geology of nonmetalliferous deposits, and glacial and physiographic geology became vacant within the year and have not yet been filled. The designation of the geologist in charge of the division was changed from geologist in charge of geology to chief geologist. 
PERSONNEL.

The scientific force of the division at the beginning of the year consisted of 43 geologists, 3 paleontologists, 38 assistant geologists, and 5 geologic aids. Of these, 24 geologists and paleontologists, 21 assistant geologists, and 6 aids were occupied continuously throughout the year; the remainder, being on the per diem roll, gave only a portion of their time or none at all to Survey work. During the year resignations and appointments resulted in a net gain of 24 in the force. In addition to the above regular force, 32 field assistants were employed for a portion of the year.

\section{CLASSIFICATION OF WORK.}

The work of the division may be roughly grouped in the following six classes, the table also showing the percentage of the available funds devoted to each class of work:

Classification of geologic and paleontologic work.

Per cent.

1. Areal and stratigraphic geology, with incidental study of economic mineral deposits

2. Economic geology, with incidental study of areal and stratigraphic problems

3. Investigation of geology of mineral deposits

4. Investigation of paleontologic and stratigraphic geology______-_-___- 17

5. Investigation of glacial and physiographic geology

6. Supervision and administration

\section{ALLOTMENTS OF FUNDS.}

The appropriations for geology and paleontology were allotted as follows :

\section{Allotments for geologic work.}

Work by States and Territories:

Arizona (western), reconnaissance surveys

Arkansas (northern), areal and economic surveys

Arkansas (northern), coal lands

1,900

California, hydraulic mining investigation.

California, earthquake investigation

California, oil fields

Colorado, areal and economic surveys

Colorado, Georgetown mining district.

Illinois, coal fields

Indian Territory. (See Utah.)

Maine, peat and pegmatites

3,838

Missouri, St. Louis quadrangle, areal and economic survey

Missouri, lead and zinc deposits of the Wyandotte, Missouri-Okla-

homa, quadrangle. 
Work by States and Territories-Continued.

New Jersey, crystalline and metamorphic rocks

$\$ 1,325$

New Jersey, mineralogy of the Franklin Furnace district

New York, Catatonk-Watkins Glen geologic folio

Oklahoma. (See Missouri.)

Oregon, areal and economic survey of Riddles quadrangle

4,637

Pennsylvania (southeastern), iron-ore deposits

2,666

Pennsylvania (southeastern), areal and economic surveys in crystalline and metamorphic rocks

Texas, Van Horn quadrangle

3,982

Utah and Indian Territory, coal fields

Wyoming, iron-ore and limestone deposits

1,450

Wyoming, radioactivity of Yellowstone Park waters ___________ 500

General investigations:

Adirondack stratigraphy

Appalachian (northern) coal fields_._.

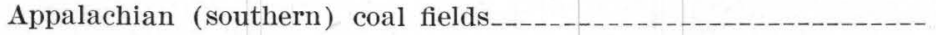

Appalachian (southern) iron ores_._._.

Appalachian (northern) oil fields and oil deposits in general_......

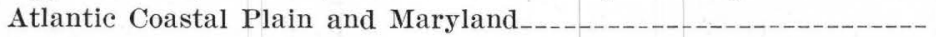

Cambrian stratigraphy and paleontology _._._._.

Carboniferous stratigraphy

Carboniferous paleontology and stratigraphy of coal measures__-_-_

Copper deposits in general

Cretaceous stratigraphy and supervision of paleontologic work

Devonian stratigraphy and paleontology

9,335

3,280

2,917

2,200

1,350

3,918

2,864

3,335

1,461

3,296

950

Editing geologic maps and areal and economic surveys in Pennsylvania, Maryland, and West Virginia

3,120

Geologic map of North America and of the United States

2,236

Glacial geology of Great Lakes region and New England

7,330

Glacial geology of the Sierra Nevada

2,850

Lead and zinc deposits in general and economic geology of the Park City, Utah, mining district.

1,710

Magnesite deposits and steel-hardening metals

2,651

Supervision of areal geology and work in Massachusetts, North Carolina, and Georgia

Metalliferous ores in general and geology of the Leadville, Colo., district

New England granite deposits

Ordovician and Silurian stratigraphy and paleontology

Rocky Mountain coal fields.

Supervision of geologic work in general

Triassic stratigraphy and paleontology of the Pacific cost---_--

Administrative salaries

24,041

5,072

482

Administrative salaries_-_-_-

12,908

14,431

Petrographic laboratory _- 590

Repair of instruments

Skilled labor

Stationery _- 2,365

Technical salaries

Contingent

Total appropriation 
Allotments for paleontologic work.

Coal-measure stratigraphy

Fossil corals

Post-Paleozoic paleobotany and stratigraphy

Tertiary paleontology and stratigraphy

Triassic paleontology and stratigraphy.

Vertebrate paleontology

Administrative salaries

Stationery

Contingent

'Total appropriation

14,000

GEOLOGIC WORK IN EASTERN AND SOUTHEASTERN STATES.

New England.-A report on the granites of Maine, based on the previous season's field work, was completed early in the year by T. Nelson Dale. A thorough examination of the granite quarries and the granite industry in eastern Massachusetts and Rhode Island, similar to the examination of the Maine granites completed during the previous year, was made by Mr. Dale, and progress was made in the preparation of a report on the granite industry of southeastern New England.

Under the direction of George Otis Smith, Edson S. Bastin was engaged in field work and the preparation of reports on the peat and pegmatites of Maine. The Maine State Survey Commission cooperated in this geologic work by an allotment of $\$ 1,600$. In June Mr. Bastin began the survey of the Eastport quadrangle for folio publication.

A survey of the area in Massachusetts covered by the Worcester, Marlboro, Webster, and Blackstone quadrangles was completed, and the Ware and Quinsigamond folios have been submitted by B. K. Emerson for publication. He has also carried forward work upon the compilation of the general geologic map of the States of Massachusetts and Rhode Island on a scale of 1 inch to 4 miles.

Before the publication of the Quinsigamond and Ware folios, Massachusetts, for which the geology of the crystalline rocks had been prepared by B. K. Emerson, it seemed desirable that the glacial deposits should be examined by a special expert. W. C. Alden, whose long training with Prof. T. C. Chamberlin eminently fitted him for this work, was therefore detailed to Massachusetts, and completed the study of the glacial deposits and the Pleistocene history of this region.

A survey of the glacial geology for the Housatonic and Taconic folios in Massachusetts and New York was continued from the previous season and completed by F. B. Taylor.

Atlantic Coastal Plain.-The study of the Atlantic Coastal Plain from New Jersey to South Carolina was continued under the supervision of William B. Clark. 
In New Jersey some revision work was done on the Philadelphia and Trenton folios, chiefly for the purpose of correlating the Cretaceous and Tertiary formations with areas farther south. Professor Clark was assisted in this work by B. L. Miller and E. W. Berry.

In Delaware areal work was begun on the Wilmington quadrangle, and a reconnaissance of the several formations was made to procure data for the correlation of formations with those lying farther north and south. Most of the work in Delaware was done by B. L. Miller.

In Maryland the survey of the Tolchester quadrangle is nearly completed, and the Patuxent folio has already been submitted for publication.

A reconnaissance was made of portions of the Coastal Plain in Virginia, attention being given chiefly to Tertiary formations and to the determination of the divisions recognized in the Potomac section. This work was carried on by B. L. Miller, who devoted some time during the winter to the study of the fossils collected in earlier years as well as during the last field season.

In North Carolina field work was carried on in cooperation with the North Carolina Geological Survey by L. W. Stephenson, E. W. Berry, and B. L. Miller. Careful study was made of the Cretaceous formations of North Carolina and adjacent areas in South Carolina, and extensive collections of invertebrate and plant fossils were made.

Northern Appalachian region.-The report on the areal geology of the Watkins Glen and Catatonk quadrangles, New York, which was in its main features ready for publication at the close of last year, was referred back for critical study and elaboration by H. S. Williams. The whole area was restudied in greater detail, and the resulting correlations and classification are based upon exact paleontologic definitions of the various formations.

The relations of the Devonian and Carboniferous beds in New York and Pennsylvania were studied for six weeks by George H. Girty, and extensive collections of fossils were made from them.

The mapping of the gneisses and limestones of the Franklin Furnace special quadrangle was completed by A. C. Spencer, and the folio was prepared for publication.

The report on the investigation of the mineralogy of the Franklin Furnace district, New Jersey, was completed by Charles Palache, and a report is in preparation.

The mapping of the crystalline rocks of the Greenwood Lake quadrangle, in New Jersey and New York, was practically completed by W. S. Bayley, and some revision work was done on the crystalline rocks of the Raritan quadrangle, New Jersey.

Reports have been prepared on the pre-Cambrian rocks of the Passaic and Raritan quadrangles.

28 GEOL $-07-2$ 
Geologic work in Pennsylvania was done in cooperation with the State, which had made an appropriation of $\$ 4,000$ for this purpose. Detailed areal and economic surveys of the Johnstown, Clarion, and Sewickley quadrangles were nearly or quite completed. Additional work was done on the Punxsutawney, Curwensville, and Houtzdale quadrangles, Pennsylvania. The work in Pennsylvania was in charge of George H. Ashley, with whom were associated W. C. Phalen, Edwin F. Lines, M. J. Munn, F. B. Peck, and Lawrence Martin.

The surveys of the Nicholas quadrangle, in West Virginia, and the Kenova quadrangle, in Kentucky, Ohio, and West Virginia, were completed, and reports on these quadrangles were prepared for publication by Messrs. Ashley and Phalen.

A reconnaissance study was made of the Elkhorn coal field of Kentucky and of the Dickinson County coal field of Virginia by R. W. Stone, under the general supervision of Mr. Ashley.

A study of the geologic occurrence of the magnetite deposits of the Cornwall type in Berks and Lebanon counties, Pa., was made in October and November by A. C. Spencer. A preliminary account of this work was published in Bulletin No. 315, and the full report is in preparation.

Interesting deposits of white clay and of phosphate used in the production of phosphorus were examined in the vicinity of Mount Holly Springs, Pa., by G. W. Stose, and reports on these deposits were prepared for publication.

Construction of a combined paleobotanic and stratigraphic section of the Pennsylvanian series across the central Appalachian trough was continued by C. D. White. This section has now been carried from the western border of the coal field in Kentucky eastward a little beyond Pikeville, the paleobotanic work being extended to the new Elkhorn coal field.

The investigation of the stratigraphy and faunal relations of the Ordovician limestones in the Mercersburg and Chambersburg quadrangles, Pennsylvania, was carried on by G. W. Stose, in association with E. O. Ulrich, and the final maps and report on this region were prepared by Mr. Stose.

Additional work, found to be necessary for the adequate subdivision of Devonian formations in the Hancock, Pawpaw, Flintstone, and Frostburg quadrangles was carried on in cooperation with the Maryland Geological Survey by C. K. Swartz. This work was resumed in June, 1907.

The study of the stratigraphy and paleontology of the valley of Virginia was continued for a month in the latter part of the field season by R. S. Bassler, under the direction of E. O. Ulrich. 
Southern Appalachian region.-The survey of the Birmingham district, Alabama, was continued from July to October by Charles Butts. Work on the Leeds and Bessemer 15-minute quadrangles, Alabama, was completed, and parts of the Birmingham and Coalville 15-minute quadrangles were resurveyed. This work consists of a detailed investigation of the stratigraphy and structure of the region, which have an intimate bearing on the economical development of the mineral resources. Special attention is given to the tracing out of formations with which the coal, iron, and flux materials are associated.

During the winter a report was prepared on the Cahaba coal field. Certain features of the geology of the region which required reexamination were reviewed by Mr. Butts in May and June, 1907.

Under instructions from the Secretary, Mr. Butts was detailed to the General Land Office for a few weeks for the examination and reclassification of the public lands of Alabama.

The detailed study of the Dahlonega district, Georgia, was completed by Arthur Keith.

Final details regarding the iron-ore deposits and the highly faulted Cambrian strata were secured by Mr. Keith for the Roan Mountain quadrangle, Tennessee, and the folio covering this quadrangle was prepared and submitted for publication.

\section{GEOLOGIC WORK IN CENTRAL STATES EAST OF $97^{\circ}$.}

A detailed survey was made of the Flushing quadrangle, Ohio, under the direction of W. T. Griswold, for the purpose of determining with more accuracy the structure of the oil sands and favorable localities for the extension of oil prospecting.

Collections of fossils from the basal Ordovician rocks in the Wells Creek basin in central Tennessee were made by R. S. Bassler, under the direction of E. O. Ulrich.

In cooperation with the Illinois Geological Survey, a paleobotanic reconnaissance of the Illinois coal field was made by C. D. White. This work was resumed in the spring of 1907.

The Eldorado and New Haven quadrangles, in southern Illinois, were surveyed by F. W. De Wolf, special attention being given to the economic geology.

A preliminary report was made by Mr. De Wolf on the SalineGallatin coal field of Illinois and published in "Contributions to Economic Geology, 1906." This work was done in cooperation with the State Survey.

An areal and economic survey was made of the east and west St. Louis quadrangles in cooperation with the State Survey of Illinois. About one-half of the area lies in. Illinois, and the expenses of the 
work in this area were paid by the State. The work was in charge of N. M. Fenneman.

A few days were spent by E. M. Kindle in Illinois and Iowa studying the Devonian and Silurian stratigraphy and paleontology of those States.

The glacial and associated formations over a large tract bordering the north and west sides of the driftless area of the upper Mississippi Valley in Wisconsin, Minnesota, and Iowa were studied by Frank Leverett. This work was done under the immediate supervision of T. C. Chamberlin.

The active exploration of the iron-ore deposits in the Lake Superior region has developed many geologic facts. These were collected by C. K. Leith, and will be utilized in the final report on the geology of the Lake Superior district in a discussion of the origin of the iron ores.

An investigation was made during the year on the minerals associated with the copper deposits of the Keweenawan Peninsula, Michigan, and the report on the investigations is in preparation by Charles Palache.

The study of the stratigraphy and paleontology of the Ozark uplift was continued during July and August and part of September by E. O. Ulrich. The stratigraphic studies were extended around the southwestern and northwestern quarters of the Ozark area in Missouri, and a continuous section was made across the uplift.

Field work was carried on from October 1, 1906, to June 1, 1907, in the survey of the Wyandotte quadrangle in Kansas, Missouri, and Indian Territory by C. E. Siebenthal. Special attention was paid to the study of the lead and zinc deposits in that district, and reconnaissance examinations were made of the region intervening between the Wyandotte and the Independence (Kans.) quadrangles.

The survey of the Arkansas coal field was completed early in the year, and a full report on this field has been prepared by A. J. Collier.

A report on the faunas of the Guadalupian series, of the Manzano group, and of the Caney shale of Arkansas and Indian Territory was completed during the year by Mr. Girty and is ready for publication.

The northern half of the Eureka Springs (Ark.) quadrangle was reexamined in the early part of July by E. O. Ulrich and A. H. Purdue, to determine certain questions of geologic correlation.

The northern portion of the Harrison (Ark.) quadrangle was mapped in July and August by.Mr. Purdue.

An examination of the phosphate deposits of northern Arkansas was made in August and September by Mr. Purdue, and a report on 
these deposits was prepared for the annual economic bulletin (No. $315)$.

The State of Arkansas has appropriated money for the cooperative investigation of the slate deposits of that State. This work has been placed in charge of A. H. Purdue, State geologist, and work was begun June 15.

GEOLOGIC WORK IN THE 16 WESTERN PUBLIC-LAND STATES AND TERRITORIES.

Rocky Mountain region.-In view of the urgent demand on the part of the public and of the Government for information regarding the western coal fields, special attention was paid to this subject. The work was placed under the immediate supervision of M. R. Campbell.

A survey was made of the western edge of the Durango-Gallup coal field, in Colorado and New Mexico, from Durango to the southern point of the field, near the Zuni Salt Lake. This party was in charge of M. K. Shaler.

The Book Cliffs coal field was examined from Grand River, Colorado, westward to Sunnyside, Utah. This work, by George B. Richardson, there connected with the work done the previous season by J. A. Taff.

The survey of the Yampa field, Colorado, begun in 1905, was continued southward to include the area of the Danforth Hills and Grand Hogback as far as Newcastle, on Grand River. This survey, as well as that of the Yampa field, was made by H. S. Gale.

In Wyoming the survey of the Uinta County coal field, made the previous year, was continued northward from Kemmerer to Snake River. This region, covered by A. R. Schultz, is exceptionally rough and mountainous, and the survey was carried on under serious disadvantages. The Carbon County coal field was surveyed by A. C. Veatch.

In Montana the Great Falls coal field, in Cascade County, was surveyed, by C. A. Fisher, from the Missouri River eastward to Stanford. In the eastern part of the State a rapid reconnaissance was made, by A. G. Leonard, of the coal field from Glendive to Miles City and thence northward to Hell Creek, on Missouri River.

At the request of the Department of Justice careful surveys were made of a part of the Book Cliffs coal field of Utah and of the Durango field of Colorado, in order to obtain data on which to base a classification of the lands. This was accomplished through the detail of J. A. Taff, a Survey geologist, to the Department of Justice. The specific information required by that Department was furnished and the geologic results were made available for publication in Survey reports.

Very little topographic work had been done in these fields, and it therefore was necessary for the geologists to prepare the topographic 
bases on which to present the geology. Special attention was paid to the determination of land lines on the ground wherever possible, and coal areas were segregated with reference to land corners. Plats showing classification of the land by legal subdivisions have been transmitted to the Land Office. Brief reports on these surveys have been prepared and transmitted for publication.

A special study of the stratigraphy and paleontology of the Dakota and associated formations in central Kansas and in Colorado along the foothills from the Cache la Poudre, near Fort Collins, to Canyon was made by T. W. Stanton.

The Cretaceous sections near Cerrillos and on Rio Puerco west of Albuquerque, N. Mex., were studied by Mr. Stanton, and collections were obtained from various horizons for purposes of correlation with adjacent areas on the west and north.

In October a brief study was made by Mr. Stanton of certain important locations in the Comanche series of Texas, on Devils River, near Del Rio, and on Bluff Creek, near Crawford.

In June, 1907, work was renewed in western Colorado by Mr. Stanton, who, with H. S. Gale, reviewed the sections studied by him during the previous field season between Newcastle, on Grand River, and Craig, on Yampa River.

The areal survey of the Engineer Mountain quadrangle, Colorado, was completed by Whitman Cross, and progress was made in the survey of the Lake City quadrangle, which was nearly completed. Surveys were also extended over a portion of the San Cristobal quadrangle, Colorado, chiefly by Albert Johannsen, under the direction of Mr. Cross. Reports on the results of the reconnaissance in western Colorado and eastern Utah in the season of 1905 were prepared by Mr. Cross, and also the Engineer Mountain folio. The results of studies of several years past in the San Juan Mountains have been correlated, and progress has been made in the preparation of reports.

A detailed areal survey was made of the Philipsburg (Mont.) quadrangle by F. C. Calkins. The quadrangle contains some important mineral deposits, which were studied in detail by a separate party, the work of Mr. Calkins forming the basis for such economic studies. Further work will be required for the completion of this quadrangle next year; it was begun by Mr. Calkins in June.

The detailed survey of the iron-ore deposits of the Iron Springs district, in southern Utah, was completed in the year by C. K. Leith and E. C. Harder. A month was devoted by Messrs. E. C. Harder and Freeman Ward to the study of the iron ores of Asheroft and White Pine, and a short report on these deposits has been prepared.

A reconnaissance survey of the Uinta Range in Utah and a preliminary investigation of the recently discovered phosphate deposits 
in Idaho, Wyoming, and Utah was made by F. B. Weeks. A brief paper on this work was published in Bulletin No. 315.

The section of economic geology of metalliferous deposits remained in charge of S. F. Emmons until March 1, 1907, when Mr. Emmons, at his own request, was relieved of the duties, and Waldemar Lindgren was placed in charge of the section.

Progress has been made in the preparation and publication of reports on the Leadville district, Colorado, and sufficient work has been done in the field to bring the information up to date. A preliminary bulletin describing the Downtown district was prepared and is now published. (Bulletin No. 320.) A general map of the district, with detailed large-scale special maps, is in an advanced state of preparation.

An advance report on some of the new mining districts of Nevada was completed by F. L. Ransome early in July (1906) and has been published as Bulletin No. 303. This gives a preliminary account of Goldfield, Bullfrog, and other mining districts in southern Nevada, and is accompanied with notes on the Manhattan djstrict by G. H. Garrey and W. H. Emmons.

Progress has been made on the final report on the geology and ore deposits of the Cour d'Alene district, in Idaho, by F. L. Ransome and F. C. Calkins.

In October a preliminary examination of the Tombstone district, Wyoming, was made by Mr. Ransome.

The final report on the Park City mining district, Utah, was well advanced during the year by J. M. Boutwell, and a preliminary paper giving the results of greatest scientific and economic importance is now about ready for the printer.

A detailed investigation of the copper deposits of Shasta County, Cal., was made by L. C. Graton. A study of the areal geology of the Redding quadrangle had already been completed by J. S. Diller, and preliminary reports had been published on the mineral resources. The present work, however, is much more detailed than any previously undertaken in this region.

A general report on certain mining districts in northern New Mexico, examined by Mr. Graton in 1905, has been made ready for publication.

A detailed investigation was made of the mineral deposits of the Philipsburg quadrangle, Montana, by W. H. Emmons, who prepared a preliminary report on this district, which was published in the annual economic bulletin (No. 315).

The field study of the Bullfrog mining district, Nevada, was completed in January and February by W. H. Emmons, and the report on this district is approaching completion. 
Numerous deposits of molybdenum and tungsten ores in Utah, California, and Arizona were visited by F. L. Hess, and a beginning was made in the field work necessary for the preparation of a report on the steel-hardening and other rare metals of the United States, which will be continued during the present year.

Under instructions from the Secretary, A. J. Collier was detailed to cooperate with officials of the General Land Office in the investigation of alleged mineral lands in the Colville Indian Reservation, Wash. This investigation extended from July to September.

In June, 1907, an examination was made by Mr. Collier of the recently discovered deposits of tin ore near Spokane, Wash. These deposits present points of special interest, and $\mathrm{Mr}$. Collier was selected for their examination on account of the familiarity with tin deposits gained by him during his work in Alaska.

A thorough investigation of the thermal waters of the Yellowstone National Park was made by R. D. Moore and Herman Schlundt for determining its radioactive properties. Important and valuable results of both positive and negative character were obtained.

A reconnaissance examination was made of portions of the Burnet and Llano quadrangles, Texas, by F. L. Hess, chiefly for the purpose of determining the necessity for future detailed work in that region.

Pacific coast.-The report on the auriferous gravels of the Sierra Nevada, based upon field work accomplished in previous years, was completed by Waldemar Lindgren.

A detailed investigation was made of the magnesite deposits of California by F. L. Hess, and progress has been made in the preparation of a report.

A detailed areal and economic survey was made of the northern half of the Riddles quadrangle, Oregon, by J. S. Diller. The quadrangle contains important mineral deposits, and a paper on the nickel deposits of Nickel Mountain was prepared by G. F. Kay for the economic bulletin (No. 315). This work on the Riddles quadrangle was resumed in June and continued to the end of the fiscal year. September was spent by Mr. Diller in reviewing portions of the Roseburg quadrangle and completing a paper on the Mesozoic sediments of southwestern Oregon.

Several weeks were spent by Mr. Diller in northern California, completing field work for a paper on the geology of the Taylorsville region, which is now in course of publication as a Survey bulletin.

Detailed surveys were made of the Santa Maria and the Summerland oil districts, in Santa Barbara County, Cal., by Ralph Arnold. Special attention was given to the study of the stratigraphy and structure of these fields, with a view to furnishing information as to the extension of the productive area and for decreasing the cost of 
production by reducing the number of dry holes drilled. Reports on these districts were prepared. A preliminary one on the Santa Maria has been published (Bulletin No. 317) and the final (Bulletin No. 322 ) is in type. The report on the Summerland district is also in type. (Bulletin No. 321.)

Similar work was begun in June, 1907, on the Coalinga, McKittrick, Midway, and Sunset districts, which will be completed during the present fiscal year.

The investigation of glacial phenomena of the Sierra Nevada was continued by W. D. Johnson. Four months were spent in field studies, the inquiry being thereby extended from the basin of Walker River, in California and Nevada, into the contiguous basin of Lake Mono on the southeast. During the last half of the year the preparation of a report was continued by Mr. Johnson, with some field work, the office work being carried on in the vicinity of the field of study.

The investigation of the Triassic stratigraphy and paleontology of central Nevada was continued by J. P. Smith. Similar work was extended to southeastern Idaho, in Bear Lake and Bannock counties, where large collections of fossils were made and the stratigraphy was carefully worked out. A report was prepared on all material collected during the present and previous years and will soon be submitted for publication. This report will include an account of the entire marine Middle Triassic invertebrate fauna of America, with descriptions of several new genera, of some genera not heretofore described for America, and of a great number of new species.

Immediately after the occurrence of the San Francisco earthquake of April 18, 1906, the governor of California appointed a State earthquake investigation commission to make a study of its physical features. Two members of the Geological Survey, G. K. Gilbert and Harry Fielding Reid, were named as members of this commission. The Carnegie Institution of Washington and the Geological Survey have cooperated with the State in promoting the work of the commission, and the final report of the commission is to be issued by the Carnegie Institution.

Mr. Gilbert's chief contribution to the investigation was a report based on a field study of the part of Marin County about Bolinas and Tomales bays, a region which is traversed by the fault that caused the earthquake and which includes a belt of peculiar topography resulting from earlier dislocations of similar character. A general account of the earthquake ("The earthquake as a natural phenomenon") was also prepared by Mr. Gilbert, which served as an introduction to Bulletin No. 324, a composite publication consisting of reports of special investigations made soon after the earthquake and fire by several experts under the general direction of the Geological Survey's expert in charge of the investigation of structural materials. 
GENERAL GEOLOGIC WORK.

An important investigation relating to that branch of river hydraulics which is concerned with the transportation of detritus by running water was continued in the laboratory at Berkeley, Cal., under the supervision of Mr. Gilbert. A great many experiments were made to determine the relation of detrital load to discharge of water, slope of stream bed, velocity, and other variables. This investigation promises results having an important bearing upon geologic theory. It is being carried on in cooperation with the waterresources branch and with the cooperation and assistance of the University of California, which furnishes space, power, and various important facilities.

The collection of all available data relative to earthquakes in the United States was continued throughout the year by Harry Fielding Reid. The information collected has made it possible to determine the focus and intensity of many light shocks. Arrangements have been made for the publication of these data in the Monthly Weather Review.

The permanent commission of the International Seismological Association held its first meeting in Rome last October. An appropriation was made, under the State Department, for participation on the part of the United States in this association, and Mr. Reid attended the meeting as a delegate from this country. The principal objects of the meeting were to formulate by-laws for the permanent commission, to discuss the budget, and to indicate the general policy of the association. A central bureau is to compile, study, and publish the records of all earthquakes, and the work of the association is to be confined to strictly seismologic matters. The delegates are to do all in their power to encourage seismologic studies and observations in their respective countries. Scientific questions were relegated to the general meeting of the association, which takes place next September at The Hague; and it was decided to offer a prize for the best form of seismograph presented at that meeting."

Progress was made in the preparation of a monograph on the flora of the Laramie and related formations by F. H. Knowlton. The technical descriptive portion of this work, which embraces about 450 . species, was practically completed, and much of the geologic portion was prepared.

Progress was made in the preparation of a monograph on the Pottsville floras by C. D. White, but on account of precedence being given to the examination of collections submitted by various geologists this monograph has not yet been completed.

Work on fossil corals was continued throughout the year by T. Wayland Vaughan, and considerable progress was made in the preparation of a report on the Tertiary corals of southeastern United States 
and the West Indies. In connection with this work on fossil corals, collateral studies on recent faunas were made for the purpose of obtaining additional information on the classification of corals to be applied in the study of the fossils, and for the purpose of procuring data on the factors controlling the distribution of corals, to furnish the basis for the reconstruction of the physical conditions under which the fossil faunas lived. This work has been done in large part on material collected by the Fish Commission and material in the various museums throughout the country. A report on some Madreporaria corals from French Somaliland, East Africa, was published within the year in the Proceedings of the United States National Museum, and a report on a collection of similar corals in the Hawaiian Islands has now been published as a bulletin of the Museum.

The monograph on the Ceratopsia (Monograph XLIX), begun by the late O. C. Marsh and continued by the late J. B. Hatcher, was completed by R. S. Lull and submitted for publication within the year.

Some progress was made in the preparation of the Titanothere monograph by H. F. Osborn, with the assistance of W. K. Gregory. In the preparation of the section on the geologic succession of species it was found necessary to take up the entire question of the stratigraphy of the American Eocene of the Rocky Mountain basin region in which the Eocene Titanotheres occur, and also to do some field work in the Lower Oligocene formation of the Great Plains. Two field excursions during the summer of 1906 were made by Mr. Osborn with this object in view.

Work was also continued on the Sauropoda monograph by Mr. Osborn, with the assistance of Mr. Gregory. The special studies of the year were devoted to the structure of the skull and the brain, for which a large number of drawings were completed.

An exhibit to illustrate the recent progress in geelogic science was prepared by J. S. Diller for the New York meeting of the American Association, and also an exhibit to illustrate the work of the Geological Survey for the Jamestown Exposition.

A subcommittee of the international committee on nomenclature spent some weeks in the field in the Adirondack region, and as a result of the field conference submitted a report recommending a uniform classification and nomenclature for Canadian and Únited States Survey reports.

In accordance with an agreement entered into with the geological surveys of Canada and Mexico, the United States Survey undertook the compilation of a geologic map of North America on a scale of $1: 5,000,000$. The work was placed in charge of Bailey Willis, by whom it was completed in August, 1906, and an edition of 1,500 
copies was printed by order of the Mexican Government for the International Geological Congress at Mexico. This map forms the basis of a description of the geology of North America, which is being prepared by $\mathrm{Mr}$. Willis for publication as a professional paper. The description and map are designed to constitute a report of progress in American geology and to be a material aid in teaching geology in schools and universities.

\section{DIVISION OF ALASKAN MINERAL RESOURCES.}

The work of the division of Alaskan mineral resources was carried on under the appropriation of $\$ 80,000$ for "continuation of the investigation of the mineral resources of Alaska." Under this authority the following classes of work were done: Reconnaissance and detailed geologic surveys, special investigations of mineral resources, reconnaissance and detailed topographic surveys, and investigation of water resources in reference to the supply of water available for placer mining.

\section{PERSONNEL.}

The personnel of the division included 1 geologist in charge and 9 other geologists on annual salaries. In addition to these, 4 geologists on per diem salaries were employed for a part of the time. Four topographers were continuously employed in the Alaskan work, and 2 engineers were detailed to the division, one for four months and the other for six months. Six temporary geologic assistants and 30 packers, cooks, etc., were employed in the field work for a period of from three to five months. The office force included 2 clerks on annual salaries and 1 clerk employed for six months.

\section{FIELD OPERATIONS IN SEASON OF 1906.}

In 190614 parties were engaged in field work during a period varying from two and a half to six months. Eight of these parties carried on geologic investigations, 2 made topographic surveys, 3 combined both classes of work, and 1 was employed in stream measurements and hydrographic reconnaissance. The aggregate of the areas covered by geologic reconnaissance surveys is 9,000 square miles; by detailed geologic surveys, 548 square miles. Topographic reconnaissance surveys were carried over an area of 10,768 square miles; detailed topographic surveys over an area of 40 square miles. Detailed hydrographic surveys were made of an area of 200 square miles, and reconnaissance surveys over an area of 1,000 square miles. In addition to this, of the 28 Alaskan mining districts in which work is going on 16 , including all but one of the large producing districts, were visited by members of the staff. 
The following table presents a summary of the progress of surveys since the organization of systematic work in 1898:

Progress of surveys in Alaska, in square miles.

\begin{tabular}{|c|c|c|c|c|c|c|c|}
\hline \multirow[b]{2}{*}{ Year. } & \multirow{2}{*}{$\begin{array}{l}\text { Appropria- } \\
\text { tion. }\end{array}$} & \multicolumn{2}{|c|}{ Geologic. } & \multicolumn{2}{|c|}{ Topographic. } & \multicolumn{2}{|c|}{ Hydrographic. } \\
\hline & & $\begin{array}{c}\text { Recon- } \\
\text { naissance. }\end{array}$ & Detailed. & $\begin{array}{c}\text { Recon- } \\
\text { naissance. }\end{array}$ & Detailed. & $\begin{array}{c}\text { Recon- } \\
\text { naissance. }\end{array}$ & Detailed. \\
\hline $\begin{array}{l}1898 \ldots \ldots \\
1899 \ldots \ldots \\
1900 \ldots \ldots \\
1901 \ldots \ldots \\
1902 \ldots \ldots \\
1903 \ldots \ldots \\
1904 \ldots \ldots \\
1905 \ldots \ldots \ldots \\
1906 \ldots \ldots \ldots\end{array}$ & $\begin{array}{r}\$ 46,189.60 \\
25,000.00 \\
25,000.00 \\
35,000.00 \\
60,000.00 \\
60,000.00 \\
60,000.00 \\
80,000.00 \\
80,000.00\end{array}$ & $\begin{array}{r}9,500 \\
6,000 \\
10,000 \\
12,000 \\
17,000 \\
13,000 \\
6,000 \\
8,000 \\
9,000\end{array}$ & 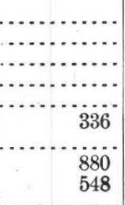 & $\begin{array}{r}14,912 \\
8,688 \\
11,152 \\
15,664 \\
20,304 \\
15,008 \\
6,480 \\
8,176 \\
10,768\end{array}$ & $\begin{array}{r}336 \\
480 \\
948 \\
40\end{array}$ & 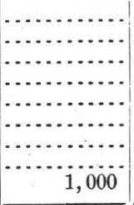 & 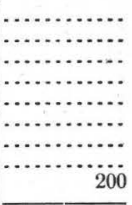 \\
\hline Total ... & $471,189.60$ & 90,500 & 1,764 & 111,152 & 1,804 & 1,000 & 200 \\
\hline
\end{tabular}

The actual areal surveys are tersely summarized in the above table, but many of the results can not be presented in this form. For example, practically every mining camp in Alaska has been investigated, and some in great detail, yet the areal results of surveys of this class are very meager. This will account for the fact that with increased appropriations there has not always been an increase in the areas surveyed. Moreover, in the last three years much of the funds has been spent in detailed surveys, which, roughly speaking, cost ten times as much as reconnaissance work.

The table shows that there remain nearly $500,000^{a}$. square miles in Alaska which have not been covered even by reconnaissance geologic surveys. Until this work is much more nearly completed all generalizations on the distribution of the mineral wealth must remain largely hypothetical.

Preliminary topographic surveys, including about 50,000 square miles done by other Government bureaus, have been carried over less than a quarter of the entire area.

GEOGRAPHIC DISTRIBUTION OF INVESTIGATIONS.

General.-As in previous years, the general administrative duties were performed by Alfred $\mathrm{H}$. Brooks, geologist in charge, who gave to them much of his time; but he also collected the statistics of the production of gold, silver, and copper. The general supervision of the topographic work was, as in previous years, intrusted to T. G. Gerdine.

In June the geologist in charge joined E. M. Kindle at Eagle, and together they made a careful study of the geology along the Yukon. The main purpose of the work was to procure data which would serve to elucidate the stratigraphic problems, but incidentally some facts 
were gathered bearing on the occurrence of placer gold and of coal. From Circle the geologist in charge went overland to Fairbanks, making an examination on the way of the Birch Creek placer district. A few days were then spent in the Fairbanks district, and at the invitation of Maj. W. P. Richardson, the geologist in charge joined the party of J. L. McPherson, engineer of the Alaska Road Commission, and carried geologic reconnaissance westward from Fairbanks to the Rapids on the Yukon, making also a brief visit to the Rampart district. The month of September was spent in Seward Peninsula with the parties working there and in making a study of the Kougarok placer district. A study of the stratigraphy of the Cretaceous and Tertiary coal-bearing rocks in the Territory was undertaken by W. W. Atwood for the purpose of establishing correlation and obtaining information on the relative commercial value of the different fields. The details of this investigation will be referred to later.

The preparation of the report on the mineral resources of the Prince William Sound region was continued by U. S. Grant.

Southeastern Alaska.-At the close of the last season the preliminary geologic mapping in southeastern Alaska was completed as far northwest as Lituya Bay. There still remains, however, the survey of the Chilkat basin, the inland parts of the larger islands, and the more inaccessible portions of the high ranges. The work of last year embraced an area of 3,000 to 4,000 square miles, extending northwestward from Lynn Canal to Lituya Bay and including a part of Chichagof Island, and was carried on by F. E. Wright and C. W. Wright, assisted by R. W. Pumpelly. Though it was principally geologic, some topographic reconnaissance surveys were made, and many data were collected on the retreat of the glaciers in the Glacier Bay region. At the close of the season C. W. Wright visited the Juneau and Ketchikan districts to collect data on the mining progress.

The urgent demand for detailed surveys of the more important mining districts in southeastern Alaska has been met, so far as the funds available would permit. In 1906 a survey was made, on a scale of a mile to the inch, of the more important parts of the Berners Bay district, embracing an area of about 40 square miles. This work was done by R. B. Oliver.

Yakutat-Alsek region.-Work in the Yakutat-Alsek Bay region was continued by R. S. Tarr and B. S. Butler. Mr. Tarr planned to cross the Malaspina Glacier to Yaktag, but the fissuring which had taken place in this ice field since his previous visit in 1905 made it impossible to carry out this plan. Mr. Tarr's observations in this region showed that an advance of some of the glaciers had taken place since 1905. This is of course exceptional for Alaskan glaciers; nevertheless, it may have an important bearing on the location of railway routes that traverse the fronts of ice sheets. 
A geologic and topographic reconnaissance survey was carried from Yakutat Bay southward to Alsek River by Eliot Blackwelder and A. G. Maddren. It was also planned to ascend that stream to the international boundary, but a serious accident, which involved the loss of one of the boats and a large part of the provisions and equipment, prevented the accomplishment of this purpose.

Controller Bay region.-The mapping of the accessible coal and oil fields of this district, begun in 1905 by G. C. Martin, was completed.

Cook Inlet region.-The stratigraphy of the lignitic coal-bearing rocks on both the east and the west shore of Cook Inlet was started by W. W. Atwood, with an assistant. This was part of the general plan to study the coal-bearing rocks of Alaska, already referred to.

A party under the direction of T. G. Gerdine made a topographic and geologic reconnaissance survey of an area covering about 7,200 square miles lying northeast of and adjacent to Cook Inlet. Mr. Gerdine, accompanied by Adolph Knopf as geologist, mapped the valley of Knik River and portions of the lower Matanuska River and the area about its headwaters from Chickaloon Creek northward. R. H. Sargent, topographer, accompanied by Sidney Paige, geologist, mapped as far as practicable the area between Susitna and Matanuska rivers as far north as Chickaloon Creek and Talkeetna River, with an additional small area south of Knik River on the east side of Knik Arm.

At the end of the season Mr. Gerdine and Mr. Sargent completed a traverse of the shore line from Knik southward to the mouth of Kusilof River, while Mr. Paige and Mr. Knopf visited the Cook Inlet placer fields.

Seward Peninsula.-The areal mapping of the Nome and Grand Central quadrangles was completed by F. H. Moffit, assisted by P. S. Smith. This work is the first attempt to make an exhaustive study of the geology of any of the placer districts. It is hoped that as a result of such investigations general laws governing the occurrence and distribution of the placer gold of the peninsula may be formulated. Mr. Smith also made a reconnaissance of some of the other placer districts of the peninsula, both to gather data on the progress of mining and also to familiarize himself with some of the larger problems of the province.

The cheaper methods of placer mining are directly dependent on an abundant supply of water; therefore a knowledge of the water supply is of first importance to this industry. The accurate determination of the mean discharge of any given stream must be based on observations extending through a long period of years, to equalize the variations caused by abnormal seasons. Such an investigation was begun at Nome last season. The area investigated embraced a belt of coun- 
try about 20 miles wide, stretching inland from Nome to the Kigluaik Mountains, a distance of about 40 miles, and was chosen both because of its commercial importance and because the detailed maps were available for calculating the areas of stream basins. It is hoped that funds may be available to continue this work and to extend it to other parts of Alaska.

These hydrographic surveys were made possible only through the cooperation of the water-resources branch, which detailed John C. Hoyt, engineer, to take charge. Mr. Hoyt spent about two months in the field, and the observations were continued by F. F. Henshaw.

Yukon district.-A geologic reconnaissance of an area of about 2,000 square miles, lying southwest of the lower Tanana, was made by L. M. Prindle, with one assistant. The Kantishna and part of the Bonnifield placer districts, as well as the Cantwell coal field, were embraced within the scope of the investigation. The stratigraphy of the Paleozoic rocks of the upper Yukon basin was studied by E. M. Kindle, with one assistant. In the course of this work Mr. Kindle ascended Porcupine River as far as the international boundary. This investigation has an important bearing on the correlation of the gold-bearing series of the Yukon-Tanana region.

Topographic reconnaissance surveys were carried westward from Fairbanks to the Yukon and southward to the Tanana by D. C. Witherspoon and R. B. Oliver. An area of 6,300 square miles was surveyed on a scale of $1: 250,000$. This completes the preliminary mapping of the Yukon-Tanana region west of the one hundred and forty-fourth meridian, except a narrow belt along the Tanana. It is expected that in another season the preliminary mapping of the area lying between Yukon and Tanana rivers and the one hundred and forty-second meridian will be completed.

\section{FIELD OPERATIONS IN SEASON OF 1907.}

Under a continuation of the same appropriation, 13 parties were dispatched to Alaska during the months of April, May, and June, while another will be sent early in July. The work of these parties includes a continuation of geologic and topographic surveys, and investigations of mineral resources in southeastern Alaska, in the Copper River region, in the Yukon basin, and in Seward Peninsula. The investigation of the water resources of the Nome region is also continued, and similar work is begun in the Fairbanks district.

\section{DIVISION OF MINING AND MINERAL RESOURCES.}

During the year the division was engaged in the preparation of reports on the mineral resources of the United States for 1905 and 1906. The report for 1905 was completed, published, and distributed, and the report for 1906 was prepared in part, manuscripts for 
many of the chapters being in hand and ready for publication as advance chapters of the volume. The figures so far in hand indicate that the year 1906 was by far the most prosperous ever known in the mining industry of the United States. The total value of all mineral products amounted last year to $\$ 1,900,000,000$, a figure unprecedented in the history of the United States and an increase of more than 17 per cent over the value of the output in 1905 .

The plan of utilizing the services of geologists in the permanent employ of the Geological Survey for the work of this division proved successful in the preparation of the report for 1905 and was continued last year. By means of this cooperation with the other divisions of the geologic branch advantage is taken of the existence in the Survey of a corps of trained men, who bring to the statistical work a keen appreciation of the geologic and economic importance of each mineral product based upon field observation. Especially successful has been the work on the subjects of gold and silver, copper, lead, zinc, and quicksilver by Waldemar Lindgren and other mining geologists. The report for 1906 will be prepared almost wholly by regular members of the Survey staff. Other divisions share the advantages of this cooperation, as the mining geologists derive from their statistical work an insight into the industrial and commercial conditions which so largely affect the demand for the different minerals.

The demand for information in regard to the black sands of the Pacific coast seemed to be sufficient to justify a continuation of that work for a short time in this fiscal year, and work was not closed there until the fall.

A considerable amount of the time of this division was consumed in answering technical inquiries and making visual examinations of several hundred mineral specimens which were submitted by the public for determination.

The chief of the division was occupied some time in organizing the mining exhibit at the Jamestown Tercentennial Exposition, in accordance with his designation for that purpose by the Secretary of the Interior, and as a member of the Government board representing the Interior Department at the exposition.

\section{DIVISION OF CHEMICAL AND PHYSICAL RESEARCH.}

In the chemical laboratory 195 quantitative analyses and 650 qualitative determinations were reported, covering the usual ground. Two of the rocks analyzed were unusual-a quartz-augite rock brought by W. T. Schaller from southern California and a pyrrhotite-bearing peridotite collected by E. S. Bastin in Maine.

In addition to the routine work of the division, scientific work was conducted as follows: A monograph on geochemistry, by F. W. 28 GEOL $-07-3$ 
Clarke, was practically finished. In October, after a conference with Sir John Murray, Mr. Clarke obtained a composite sample of the oceanic " red clay," from 51 localities, which was analyzed in the Survey laboratory. Later another composite of 52 "terrigenous" clays was received, which was also analyzed. These analyses gave the average composition of two important sediments and revealed the presence in them of several elements which had not previously been detected in material of that kind. The greater part of the material came from the collections of the Challenger expedition.

A new edition of his bulletin on rock analysis (Bulletin 305) was prepared by W. F. Hillebrand, who also studied an important series of mercury minerals from Texas and a very remarkable vanadium ore from Peru. The latter may shed some light upon the origin of our Colorado-Utah ores. These investigations were extremely difficult and thorough. A bulletin (No. 312) describing his researches upon the chemistry of secondary enrichment was prepared by E. C. Sullivan, who is continuing his investigation. Routine analyses occupied most of the time of George Steiger, but he found time to study and develop certain analytical methods, which he has much improved. The numerous mineralogical determinations which are almost daily required were in charge of W. T. Schaller, who also made some investigations of noteworthy interest. The rare mineral powellite was identified from two new localities, under conditions which indicated its genesis. The mineral molybdite, or molybdic ocher, was found by Mr. Schaller to be not molybdic oxide, as hitherto assumed, but a hydrous ferric molybdate. Analyses of material from five localities gave concordant results. An interesting series of 12 minerals from the zinc mines of Franklin, N. J., were also analyzed by Messrs. Sullivan, Steiger, and Schaller. This material gave important information regarding several imperfectly known species.

In the physical laboratory the investigation of problems in geophysics was carried on by G. F. Becker, geologist in charge of the division, who also published a paper in the American Journal of Science on "Current Theories of Slaty Cleavage." The mathematical tables noted in the last report, of which C. E. Van Orstrand is a joint author, are ready for publication. The work on elasticity was continued under the immediate supervision of Mr. Van Orstrand. A well-equipped electric furnace, together with a measuring apparatus of high precision, has been constructed and is being used in an investigation of the elastic properties of metals, particularly steels, at high temperatures. A great number of observations have been made for the purpose of determining the variation of strain with stress as dependent upon time, and the variation of temperature and electric conductivity as dependent upon strain. Some time has been given also to a study of the transmission of vibrations in an elastic solid. 
On January 1 A. L. Day, and E. T. Allen left the Survey to enter the service of the Carnegie Institution. During the first half of the fiscal year, however, they continued their researches upon the synthesis of minerals. Mr. Allen, in particular, devoted most of his time to the study of diopside and tremolite.

\section{TOPOGRAPHIC BRANCH.}

ORGANIZATION.

The organization of the topographic branch remained the same as it had been during the preceding year until March 19, 1907, up to which time H. M. Wilson, geographer, was in charge of the eastern division and E. M. Douglas, geographer, was in charge of the western division.

On March 19 five divisions were formed, the chiefs of which were to act as a topographic committee, with $\mathrm{H}$. M. Wilson as chairman. These divisions, with their chiefs, were as follows:

1. Northeastern division, H. M. Wilson, geographer, in charge, with J. H. Jennings, topographer, as assistant.

2. Southeastern division, Frank Sutton, geographer, in charge.

3. Central division, W. H. Herron, geographer, in charge.

4. Rocky Mountain division, E. C. Barnard, geographer, in charge.

5. Pacific division, R. B. Marshall, geographer, in charge.

Geographer in charge of office, E. M. Douglas.

Geographer in charge of map editing, Henry Gannett.

Three inspectors of topography were appointed-John H. Renshawe, W. M. Béaman, and F. E. Matthes.

Because of the transfer of H. M. Wilson from the topographic branch to the technologic branch, which took effect April 6, the above organization was modified as follows:

The northeastern and southeastern divisions were consolidated into the Atlantic division, with Frank Sutton, geographer, in charge, and Van H. Manning and J. H. Jennings, topographers, as assistants.

George Otis Smith, then geologist, succeeded Mr. Wilson as chairman of the topographic committee.

\section{PERSONNEL.}

The technical corps of the topographic branch was increased during the year by the appointment, under civil-service rules, of 10 topographic aids and the reinstatement of 1 , and was reduced by deaths, transfers, and resignations amounting to 16 . With these changes the technical force now includes 8 geographers, 37 topographers, 34 assistant topographers, and 10 topographic aids. Five employees of the technical corps are on leave without pay. In addition to the above regular force 209 field assistants were employed during the whole or part of the field season. 
SUMMARY OF RESULTS.

The following summary includes all small-scale topographic surveys made by the topographic branch, including those in the national forests and by the division of Alaskan mineral resources.

Triangulation stations to the number of 281 were occupied or located and marked, and 3,156 miles of primary traverse were run. In the course of this work 40,000 square miles were covered by primary control.

The condition of topographic surveys to June 1,1907, distinguished as to scale, etc., is shown on a general map of the United States (Pl. I).

As shown in the following tables giving the details of topographic mapping and spirit leveling for the fiscal year, the total of new surveys was 32,448 square miles. The total area surveyed in the United States to date is $1,025,065$ square miles, or about 33 per cent.

In addition, 1,833 square miles of revision or resurvey were completed, making the total area of actual surveys for the season 34,281 square miles.

In connection with these surveys there were run 5,797 linear miles of primary spirit levels and 1,595 miles of precise levels, making the total amount of primary and precise spirit leveling done since the authorization of this work by Congress, in 1896, 203,763 miles.

The total area covered by topographic surveys in Alaska during the fiscal year 1906-7, as reported in detail on pages 23-26, was about 10,808 square miles, 40 of which were on the scale of $1: 62,500$, and 10,768 on the scale of $1: 250,000$.

Present condition of topographic surveys of the United States, and new areas surveyed in 1906-7.

\begin{tabular}{|c|c|c|c|}
\hline State or Territory. & $\begin{array}{l}\text { New area } \\
\text { surveyed } \\
\text { in 1906-7. }\end{array}$ & $\begin{array}{c}\text { Total area } \\
\text { surveyed } \\
\text { to June } 1, \\
1907 .\end{array}$ & $\begin{array}{c}\text { Percentage } \\
\text { of total area } \\
\text { of State } \\
\text { surveyed } \\
\text { to June 1, } \\
\text { 1907. }\end{array}$ \\
\hline Alabama & Sq. miles. & Sq. miles. & \\
\hline 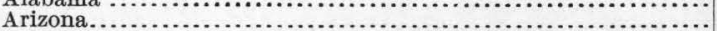 & 337 & 62,712 & $\begin{array}{l}35 \\
55\end{array}$ \\
\hline Arkansas & & 20,469 & 38 \\
\hline 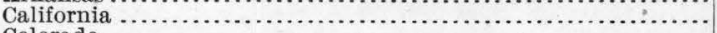 & 4,405 & 79,381 & 50 \\
\hline 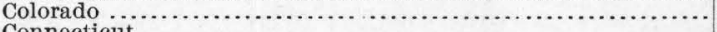 & 1,055 & 37,766 & 36 \\
\hline 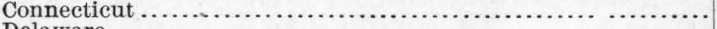 & ....... & 4,965 & 100 \\
\hline 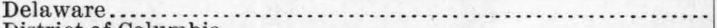 & ... & 1,008 & 43 \\
\hline 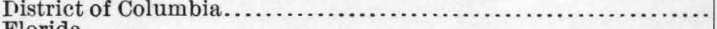 & ...... & 70 & 100 \\
\hline 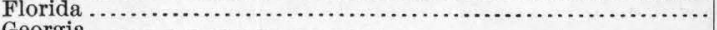 & $\cdots \cdots$ & 1.821 & \\
\hline 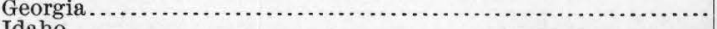 & 26 & 16,855 & 28 \\
\hline 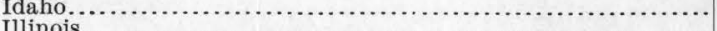 & 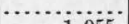 & 15,196 & 1 \\
\hline 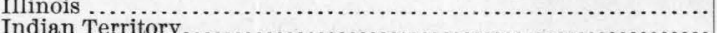 & 1,055 & 7,400 & 13 \\
\hline 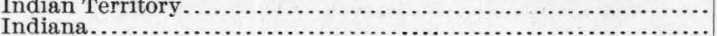 & 341 & 30,961 & 99 \\
\hline $\begin{array}{l}\text { Indiana } \\
\text { Iowa } \\
\text { 10 }\end{array}$ & 16 & 2,458 & \\
\hline $\begin{array}{l}10 w a \\
\text { Kansas }\end{array}$ & 209 & 9,895 & 18 \\
\hline 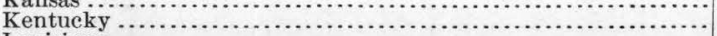 & 724 & 14,515 & \\
\hline 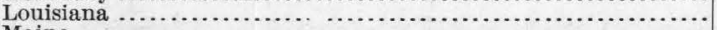 & 225 & 7,923 & \\
\hline 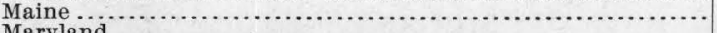 & 290 & 6,805 & \\
\hline (n) & $\cdots$ & 10,294 & 84 \\
\hline Massachus & & & 100 \\
\hline
\end{tabular}




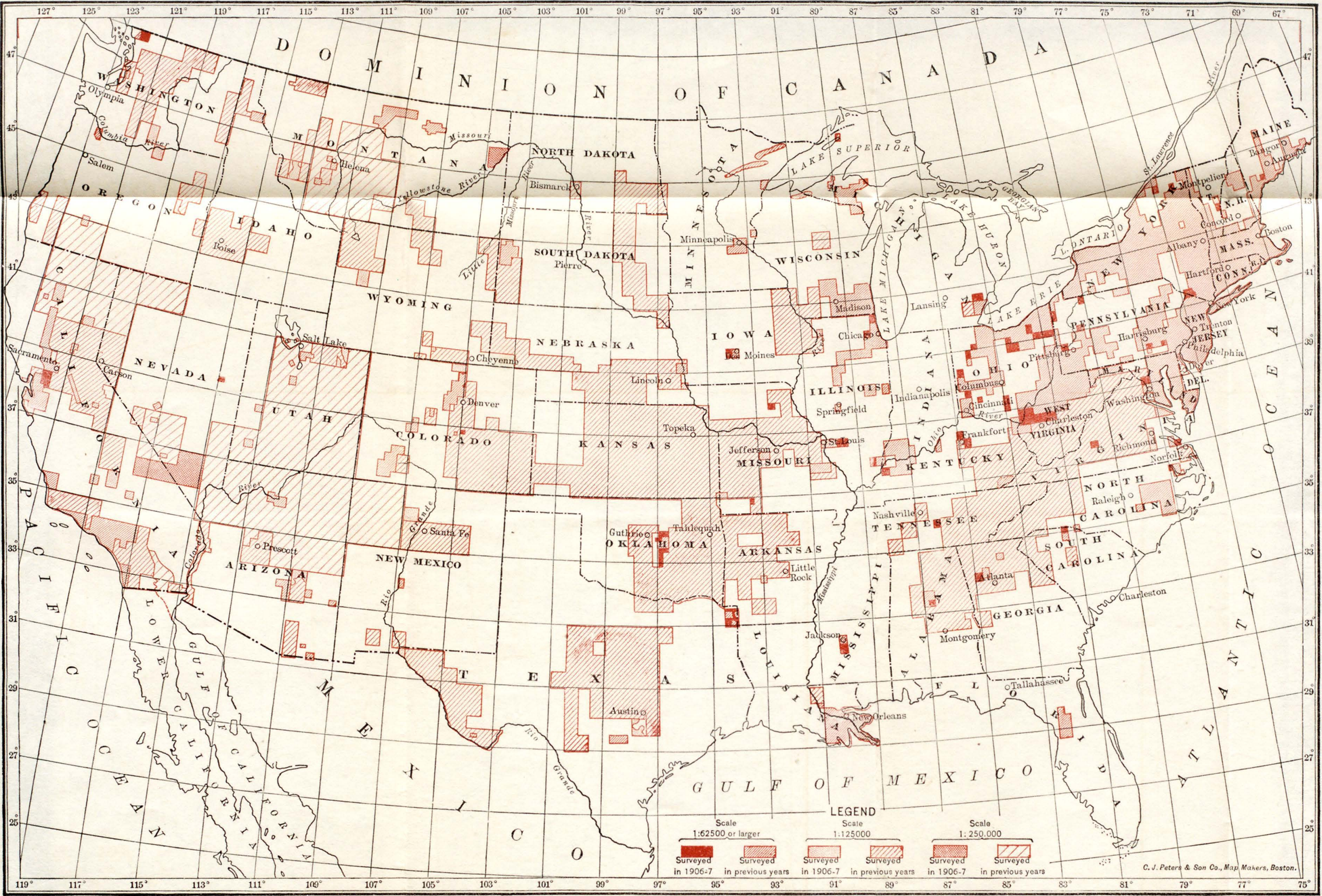

MAP OF UNITED STATES, SHOWING AREAS COVERED BY TOPOGRAPHIC SURVEYS AND THE SCALE EMPLOYED FOR EACH AREA

\begin{tabular}{rrrr}
$100 \quad 0 \quad 100 \quad 200 \quad 300$ miles \\
\hline
\end{tabular} 
Present condition of topographic surveys of the United States, and new areas sirveyed in 1906-7-Continued.

\begin{tabular}{|c|c|c|c|}
\hline State or Territory. & $\begin{array}{l}\text { New area } \\
\text { surveyed } \\
\text { in 1906-7. }\end{array}$ & $\begin{array}{c}\text { Total area } \\
\text { surveyed } \\
\text { to June } 1 \text {, } \\
1907 .\end{array}$ & $\begin{array}{c}\text { Percentage } \\
\text { of total area } \\
\text { of State } \\
\text { surveyed } \\
\text { to June 1, } \\
1907 .\end{array}$ \\
\hline Michigan ... ( & Sq. miles. & Sq. miles. & \\
\hline 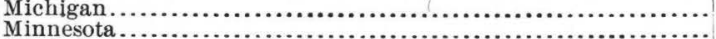 & 440 & 3,753 & \\
\hline $\begin{array}{l}\text { Minnesota } \\
\text { Mississippi. }{ }_{1}{ }_{1}\end{array}$ & 053 & 2,876 & \\
\hline & 253 & 906 & \\
\hline 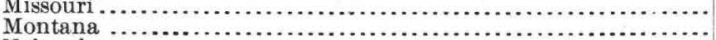 & $\begin{array}{r}528 \\
2.359\end{array}$ & 34,017 & 49 \\
\hline Nebraska & $\begin{array}{l}2,359 \\
\ldots \ldots \ldots\end{array}$ & 47,189 & 32 \\
\hline Nevada & 4,297 & 25,974 & 34 \\
\hline 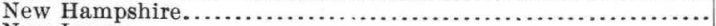 & 71 & $\begin{array}{r}40,482 \\
3,160\end{array}$ & 36 \\
\hline New Jersey ......... & & 7,821 & $\begin{array}{l}33 \\
95\end{array}$ \\
\hline New Mexico........... & 713 & 23,735 & 23 \\
\hline New York .............. & 633 & 38,209 & \\
\hline North Caroliaa ...... & 429 & 17,074 & \\
\hline 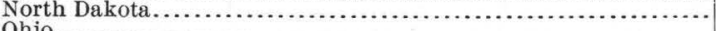 & 62 & 8,775 & 1 \\
\hline 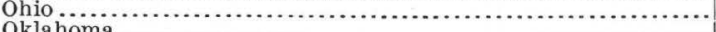 & 3,500 & 19,997 & 4 \\
\hline $\begin{array}{l}\text { Oklahoma } \\
\text { Oregon }\end{array}$ & 1,024 & 534 & \\
\hline $\begin{array}{l}\text { Oregon } \\
\text { Pennsylyania }\end{array}$ & 984 & 16,280 & 17 \\
\hline 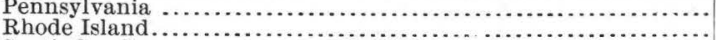 & 1,363 & 19,608 & \\
\hline 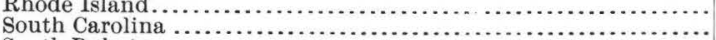 & 16 & 1,248 & 100 \\
\hline (n) & 168 & $\begin{array}{r}5,496 \\
17\end{array}$ & 17 \\
\hline Tennessee.......... & $\begin{array}{l}142 \\
242\end{array}$ & $\begin{array}{l}1 \%, 906 \\
20,103\end{array}$ & \\
\hline Texas................ & 1,306 & 65,845 & \\
\hline 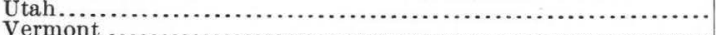 & 7 & 63,320 & 1 \\
\hline $\begin{array}{l}\text { Vermont .... } \\
\text { Virginia ..... }\end{array}$ & 74 & 3,537 & \\
\hline $\begin{array}{l}\text { Virginia } \\
\text { Washingt }\end{array}$ & 366 & 29,829 & \\
\hline $\begin{array}{l}\text { Washington .... } \\
\text { West Virginia. }\end{array}$ & 1,257 & 18,228 & \\
\hline $\begin{array}{l}\text { West Virginia. } \\
\text { Wisconsin ..... }\end{array}$ & 1, 544 & 24,120 & - \\
\hline $\begin{array}{l}\text { Wisconsin } . . . . \\
\text { Wyoming...... }\end{array}$ & 283 & 11,197 & \\
\hline wyoming...... & 913 & 22,594 & \\
\hline Total & 32,448 & $1,025,065$ & \\
\hline
\end{tabular}

\section{EASTERN DIVISION.}

FIELD WORK.

SUMMARY.

During the season topographic surveying was carried on in Alabama, Georgia, Illinois, Indiana, Indian Territory, Iowa, Kansas, Kentucky, Louisiana, Maine, Maryland, Michigan, Minnesota, Mississippi, Missouri, New Hampshire, New Jersey, New York, North Carolina, North Dakota, Ohio, Pennsylvania, South Carolina, Tennessee, Vermont, Virginia, West Virginia, and Wisconsin. The survey of 56 new quadrangles and of 1 special area was completed, also the resurvey or revision of 4 quadrangles. In addition, 14 new quadrangles were partly surveyed and 2 quadrangles and 1 special area were partly resurveyed. The total new area mapped was 13,594 square miles, of which 1,457 were for publication on the scale of $1: 125,000,12,137$ were for publication on the scale of $1: 62,500$, and 74 were for publication on the scale of $1: 24,000$. The area resurveyed was 1,044 square miles, all for publication on the scale of $1: 62,500$. In connection with this work, 3,226 miles of primary levels and 1,266 miles of precise levels were run and 1,161 permanent bench marks were established. 
T'opographic surveys in eastern division from May 1, 1906, to June 1, $190 \%$.

\begin{tabular}{|c|c|c|c|c|c|c|c|}
\hline \multirow{3}{*}{ State. } & \multirow{3}{*}{$\begin{array}{l}\text { Contour } \\
\text { interval. }\end{array}$} & \multicolumn{3}{|c|}{ Scale of publication. } & \multirow{3}{*}{$\begin{array}{c}\text { Total } \\
\text { area sur- } \\
\text { veyed. }\end{array}$} & \multicolumn{2}{|c|}{ Levels. } \\
\hline & & \multirow{2}{*}{$\frac{1: 125,000}{\text { New. }}$} & \multicolumn{2}{|c|}{ 1:62,500. } & & \multirow{2}{*}{$\begin{array}{c}\text { Distance } \\
\text { run. }\end{array}$} & \multirow{2}{*}{$\begin{array}{l}\text { Bench } \\
\text { marks. }\end{array}$} \\
\hline & & & New. & $\begin{array}{c}\text { Resur- } \\
\text { vey. }\end{array}$ & & & \\
\hline Alabama & Feet. ${ }_{50}$ & Sq. miles. & Sq. miles. & Sq. miles. & Sq. miles. & ${ }_{2}$ Miles. & \\
\hline $\begin{array}{l}\text { Georgia... } \\
\text { Illinois. }\end{array}$ & $20-50$ & 6 & 20 & 213 & 239 & 76 & \\
\hline Indiana .............. & $10-20$ & (n.......... & $\begin{array}{r}1,055 \\
16\end{array}$ & $\cdots \cdots$ & 1,055 & 413 & 142 \\
\hline Indian Territory .................. & $\begin{array}{l}20 \\
50\end{array}$ & 341 & 16 & & $\begin{array}{r}16 \\
341\end{array}$ & $\begin{array}{l}51 \\
49\end{array}$ & \\
\hline Iowa $. . . . \cdots \ldots .$. & 20 & & 209 & & 209 & 71 & \\
\hline KaI & 20 & & & & 63 & 67 & 24 \\
\hline cky ......... & 20 & a........ & 724 & $\ldots$. & 724 & 570 & 133 \\
\hline Louisiana...$\ldots \ldots \ldots \ldots \ldots$ & 10 & - $\cdots \cdots \cdots$ & 225 & ........... & 225 & 157 & 61 \\
\hline$\ldots+\ldots \ldots \ldots$ & 20 & $\cdots$ & 290 & ……… & 290 & $\begin{array}{l}131 \\
189\end{array}$ & \\
\hline ( & 20 & $\cdots \cdot$ & $\ddot{4} 40$ & & $\begin{array}{l}307 \\
440\end{array}$ & 182 & $\begin{array}{l}46 \\
21\end{array}$ \\
\hline Min & & & & & & & 10 \\
\hline Mis & 20 & & 253 & & 253 & 71 & \\
\hline (n............. & $20-50$ & 299 & 229 & 42 & 570 & 170 & 29 \\
\hline n........... & 20 & . & 71 & $\cdots$ & 71 & 75 & \\
\hline .............. & $\begin{array}{l}20 \\
20\end{array}$ & $\cdots \cdot$ & 65 & $\cdots \cdot$ & 65 & 130 & \\
\hline … & $10-20$ & $\cdots$ & $\begin{array}{l}035 \\
429\end{array}$ & $\cdots$ & $\begin{array}{l}055 \\
429\end{array}$ & $\begin{array}{l}152 \\
281\end{array}$ & $\begin{array}{l}28 \\
69\end{array}$ \\
\hline North Dakota. & 50 & 62 & & & 62 & 102 & 27 \\
\hline Ohi & $10-20$ & ................. & 3,500 & & 3,500 & 781 & 186 \\
\hline$\ldots$. & 20 & ..... & 1,363 & 105 & 1,468 & 286 & 52 \\
\hline South Ca & 20 & $\cdots$ & 168 & & 168 & 75 & 21 \\
\hline Tenn & $20-50$ & & 242 & 14 & a 268 & 131 & 39 \\
\hline Verm & 20 & ............ & 74 & & 74 & 42 & \\
\hline Virg & $10-50$ & $\cdots$ & 304 & 1 & $a 367$ & 107 & 25 \\
\hline West Virg & & $\ldots$ & 1,544 & & 1,544 & 306 & \\
\hline Wisconsin ... & $10-20$ & ..... & 283 & & 283 & 110 & 30 \\
\hline Total & & 1,457 & 12,137 & 1,044 & 14,712 & 4,514 & 1,161 \\
\hline
\end{tabular}

a 12 square miles in Tennessee and 62 square miles in Virginia for publication on the scale of $1: 24,000$.

DETAILS OF TOPOGRAPHIC FIELD WORK, BY STATES.

Alabama.-The resurvey of the Coalville quadrangle, consisting of 249 square miles in Shelby and Jefferson counties, was completed by W. M. Beaman, R. L. Harrison, and C. C. Gardner, for publication on the scale of $1: 62,500$, with a contour interval of 50 feet, in connection with which 2 miles of supplementary primary levels were run.

Alabama-Georgia.-The survey of the Opelika quadrangle, for publication on the scale of $1: 125,000$, with a contour interval of 50 feet, in Chambers and Lee counties, Ala., and Harris, Troup, and Muscogee counties, Ga., was nearly completed by J. H. Sinclair, R. W. Berry, and R. H. Reineck. The area surveyed was 755 square miles, 6 of which are in Georgia.

Georgia.-The resurvey of the Stilesboro quadrangle, in Polk, Barstow, and Paulding counties, was completed by Duncan Hannegan, who also commenced the mapping of the Columbus quadrangle, in Muscogee and Chattahoochee counties. The new area mapped was 20 square miles, the resurvey consisting of 213 square miles, all for publication on the scale of $1: 62,500$, with contour intervals of 20 and 50 feet. In connection with this work 37 miles of primary levels were run and 5 permanent bench marks were established. 
Illinois.-The governor of the State of Illinois allotted $\$ 10,000$ for cooperative topographic surveys within the State, and the Director of the Federal Survey allotted a like sum for the same purpose. The mapping of the Breese, Galatia, and Wheaton quadrangles, in Blair, Clinton, Bond, Madison, Franklin, Hamilton, Saline, Williamson, Cook, and Dupage counties was completed, and the survey of the Tallula quadrangle, in Cass, Sangamon, Morgan, and Menard counties, was commenced. This work was done by W. J. Lloyd, C. L. Sadler, C. H. Hartmann, jr., and J. G. Staack. The total area surveyed was 906 square miles, for publication on the scale of $1: 62,500$, with contour intervals of 10 and 20 feet. For the control of these and other areas 163 miles of primary levels were run and 45 permanent bench marks were established.

Illinois-Wisconsin.-The survey of the Waukegan quadrangle was completed by Messrs. Lloyd and Staack, for publication on the scale of $1: 62,500$, with a contour interval of 20 feet. The area surveyed was 160 square miles, 149 square miles being in Lake County, Ill., and 11 square miles in Kenosha County, Wis. In connection with this work 37 miles of primary levels were run and 21 permanent bench marks were established, all being in Illinois.

Indiana.-The survey of the Saline City quadrangle, in Clay, Owen, Vigo, Sullivan, and Putnam counties, was commenced by W. H. Griffin, who completed 16 square miles, for publication on the scale of $1: 62,500$, with a contour interval of 20 feet.

Indian Territory-Missouri.-The survey of the Wyandotte quadrangle, in District No. 1, Indian Territory, and Newton and McDonald counties, Mo., was commenced by C. G. Anderson and J. G. Staack. The area completed was 556 square miles, for publication on the scale of $1: 125,000$, with a contour interval of 50 feet, 341 square miles being in Indian Territory and 215 in Missouri. In connection with this work 97 miles of levels were run and 4 permanent bench marks were established, 49 miles of level line being in Indian Territory.

Iowa.-The survey of the Waukee quadrangle, in Dallas, Madison, Polk, and Warren counties, was completed by Basil Duke, the area surveyed being 209 square miles, for publication on the scale of $1: 62,500$, with a contour interval of 20 feet. For the control of this area 71 miles of primary levels were run.

Kansas-Missouri.-The resurvey of the Leavenworth quadrangle, for publication on the scale of $1: 62,500$, with a contour interval of 20 feet, was commenced by Glenn S. Smith, the area surveyed being 105 square miles, 42 square miles of which were in Platte County, Mo., and 63 square miles in Leavenworth and Atchison counties, Kans. For the control of this quadrangle 122 miles of primary levels were 
run and 34 permanent bench marks were established, 55 miles of level line and 10 bench marks being in Missouri.

Kentucky.-The director of the State Geological Survey of Kentucky allotted $\$ 10,000$ for cooperative topographic surveys in the State, and the Director of the Federal Survey allotted a like sum for the same purpose. The survey of the Georgetown, Lockport, and Morganfield quadrangles, in Woodford, Fayette, Scott, Franklin, Jessamine, Owen, Henry, Shelby, Union, Webster, Crittenden, and Henderson counties, was completed by W. J. Lloyd, W. N. Morrill, A. O. Burkland, R. W. Berry, and L. Scott Smith, and work on the Providence and Monticello quadrangles, in Union, Webster, Crittenden, Hopkins, Caldwell, Russell, Wayne, Clinton, and Pulaski counties, was-commenced. The total area surveyed was 724 square miles, for publication on the scale of $1: 62,500$, with a contour interval of 20 feet. For the control of these areas 383 miles of primary levels were run and 133 permanent bench marks were established.

Louisiana.-The mapping of the Baton Rouge quadrangle, in Baton Rouge, Iberville, and Ascension parishes, was completed by W. C. Hall and T. H. Moncure, who also commenced the survey of the Winnfield quadrangle, in Winn and Grant parishes. The total area surveyed was 225 square miles, for publication on the scale of $1: 62,500$, with a contour interval of 10 feet. For the control of the Winnfield quadrangle 24 miles of primary levels were run and 61 permanent bench marks were established.

Maine.-The State Survey Commission allotted $\$ 3,500$ for cooperative topographic surveys in Maine, and the Director of the Federal Survey allotted a like sum for the same purpose. The survey of the Lewiston quadrangle, in Androscoggin, Kennebec, and Sagadahoc counties, was completed by Glenn S. Smith, Hersey Monroe, and C. H. Hartmann, who also commenced the survey of the Poland quadrangle, in Cumberland and Oxford counties. The total area surveyed was 290 square miles, for publication on the scale of $1: 62,500$, with a contour interval of 20 feet. For the control of these quadrangles 56 miles of primary levels were run and 41 permanent bench marks were established.

Maryland.-The State geologist of Maryland allotted $\$ 5,000$ for cooperative topographic surveys in the State, and the Director of the Federal Survey allotted a like sum for the same purpose. The resurvey of the Laurel quadrangle was completed, and the resurvey of the old Frederick 30-minute quadrangle was commenced, the latter to comprise four 15-minute quadrangles, of which the Rockville was completed and the Mount Airy commenced. This work was done by Albert Pike, L. S. Leopold, W. O. Tufts, A. O. Burkland, and J. S. B. Daingerfield. The total area resurveyed was 357 square miles, in Anne Arundel, Howard, Montgomery, and Prince George counties, 
for publication on the scale of $1: 62,500$, with a contour interval of 20 feet. For the control of these and other areas 182 miles of primary levels were run and 46 permanent bench marks were established.

Michigan.-The State geologist of Michigan allotted $\$ 3,000$ for cooperative topographic surveys in that State and the Director of the Federal Survey allotted a like sum for the same purpose. The survey of the Pontiac and Rochester quadrangles, in Oakland and Macomb counties, was completed by A. M. Walker, C. H. Birdseye, and H. L. McDonald. The total area surveyed was 440 square miles, for publication on the scale of $1: 62,500$, with a contour interval of 20 feet, in connection with which 76 miles of primary levels were run and 21 permanent bench marks were established.

Minnesota.-For the control of the Rockford quadrangle, in Hennepin and Wright counties, 15 permanent bench marks were established.

Mississippi.-The survey of the Florence quadrangle, in Copiah, Rankin, Simpson, and Hinds counties, was completed by J. W. Bagley and T. H. Moncure, for publication on the scale of 1:62,500, with a contour interval of 20 feet. The area surveyed was 253 square miles, in connection with which 71 miles of primary levels were run and 5 permanent bench marks were established.

Missouri.-The survey of the Atlanta quadrangle, in Knox, Macon, and Shelby counties, was completed by T. Foster Slaughter, for publication on the scale of $1: 62,500$, with a contour interval of 20 feet. The area surveyed was 229 square miles, in connection with which 18 miles of levels were run and 4 permanent bench marks were established. The survey of the Forsyth quadrangle, in Christian, Stone, and Taney counties, was completed by C. G. Anderson. The area surveyed was 84 square miles, for publication on the scale of $1: 125,000$, with a contour interval of 50 feet, in connection with which 19 miles of primary levels were run and 4 permanent bench marks were established. For the control of the Macon quadrangle, in Macon, Monroe, Randolph, and Shelby counties, 30 miles of primary levels were run and 7 permanent bench marks were established.

New Hampshire-Vermont.-The survey of the Hanover quadrangle was completed by Charles Hartmann, jr., for publication on the scale of $1: 62,500$, with a contour interval of 20 feet. The area surveyed was 216 square miles, 71 of which were in Grafton and Sullivan counties, N. H., and 145 in Windsor County, Vt. For the control of this work 19 miles of primary levels were run and 5 permanent bench marks were established, all being in Vermont.

New York.-The State engineer and surveyor allotted $\$ 9,500$ for the continuation of cooperative topographic surveys in the State and the Director of the Federal Survey allotted a like sum for the same purpose. The survey of the Loon Lake, Potsdam, and Goshen quadrangles, in Franklin, St. Lawrence, and Orange counties, was com- 
pleted by J. H. Jennings, C. E. Cooke, Gilbert Young, W. O. Tufts, and Fred Graff,jr.; also the Port Jervis quadrangle, in Orange and Sullivan counties, N. Y., and Sussex County, N. J. All this work was done for publication on the scale of $1: 62,500$, with a contour interval of 20 feet. The total new area surveyed was 633 square miles in New York and 65 square miles in New Jersey. For the control of this work 132 miles of levels were run and 28 permanent bench marks were established.

North Carolina.-The commissioner of agriculture of North Carolina allotted $\$ 4,000$ for the continuation of cooperative topographic surveys in the State, and the Director of the Federal Survey allotted a like amount for the same purpose. The survey of the Beckford, Four Oaks, and Winton quadrangles, in Chowan, Gates, Hertford, Perquimans, Johnston, Wayne, Sampson, Hartnett, and Bertie counties, was completed by W. C. Hall, C. D. S. Clarkson, W. O. Tufts, and F. Graff, jr. The area surveyed was 353 square miles, for publication on the scale of $1: 62,500$, with a contour interval of 10 feet. For the control of this work and that in the Salemberg quadrangle, 224 miles of primary levels were run and 51 permanent bench marks were established.

North Carolina-South Carolina.-The survey of the Kings Mountain quadrangle was completed by W. L. Miller and T. H. Moncure, for publication on the scale of 1:62,500, with a contour interval of 20 feet. The area surveyed was 244 square miles, 76 square miles of which were in Cleveland and Gaston counties, N. C., and 168 square miles in York and Cherokee counties, S. C. For the control of this and the Gaffney quadrangle, in Cleveland and Rutherford counties, N. C., and Cherokee County, S. C., 132 miles of primary levels were run and 39 permanent bench marks were established, 75 miles of levels and 21 bench marks being in South Carolina.

North Dakota.-The survey of the Ray quadrangle, in Wallace and Williams counties, was commenced by Basil Duke, who completed 62 square miles, for publication on the scale of $1: 125,000$, with a contour interval of 50 feet, in connection with which 102 miles of primary levels were run and 27 permanent bench marks were established.

Ohio.-The governor of the State of Ohio allotted $\$ 23,800$ for the continuation of cooperative topographic surveys, and the Director of the Federal Survey allotted a like sum for the same purpose. The following quadrangles were completed: Ashland, in Ashland, Richland, and Huron counties; Bidwell, in Gallia; Jackson, and Lawrence counties; Chillicothe, in Ross, Vinton, and Pickaway counties; Chagrin Falls, in Cuyahoga, Geauga, Summit, and Portage counties; Columbus Grove, in Putnam and Allen counties; Deshler, in Henry, Wood, Hancock, and Putnam counties; Middletown, in Butler, 
Preble, Montgomery, and Warren counties; New London, in Ashland, Huron, and Lorain counties; Ravenna, in Mahoning, Portage, and Trumbull counties; St. Henry, in Mercer and Darke counties; Warren, in Mahoning and Trumbull counties; Waverly, in Ross, Pike, Jackson, and Vinton counties; West Salem, in Ashland, Medina, and Wayne counties; Youngstown, in Mahoning and Trumbull counties; and, in addition, the Ohio portion of the Athalia, Point Pleasant, Ravenswood, and Glenwood quadrangles, in Lawrence, Gallia, and Meigs counties. This work was all for publication on the scale of 1:62,500, with contour intervals of 10 and 20 feet, and was done by M. Hackett, W. H. Lovell, Basil Duke, C. W. Goodlove, W. L. Miller, W. H. Griffin, R. C. McKinney, D. C. Harrison, W. C. Hall, C. H. Birdseye, J. M. Whitman, H. L. McDonald, J. I. Gayetty, J. R. Eakin, W. H. S. Morey, C. F. Eberly, and R. H. Reineck. In all there were mapped 3,500 square miles, in connection with which 507 miles of primary levels were run and 186 permanent bench marks were established.

Pennsylvania.-The State Survey Commission of Pennsylvania allotted $\$ 14,000$ for cooperative topographic surveys in that State and the Director of the Federal Survey allotted a like sum for the same purpose. The survey of the following quadrangles was completed: Clarion, in Armstrong and Clarion counties; Linesville, in Crawford County; Middletown, in Dauphin, Lancaster, Lebanon, and York counties; New Holland, in Berks and Lancaster counties; Sewickley, in Allegheny, Beaver, and Butler counties; Warren, in Warren County; and, in addition, the Pennsylvania portion of the Port Jervis quadrangle, in Pike County. The survey of the Foxburg quadrangle, in Armstrong, Butler, Clarion, and Venango counties, was not completed. This work was all for publication on the scale of $1: 62,600$, with a contour interval of 20 feet, and was done by R. D. Cummin, A. C. Roberts, C. C. Bassett, Duncan Hannegan, E. B. Clark, J. W. Bagley, Gilbert Young, I. M. Flocker, W. O. Tufts, M. J. Munn, C. G. Anderson, E. W. McCrary, and B. D. Stewart. In all there were mapped 1,363 square miles of new area, in connection with which 286 miles of primary levels were run and 52 permanent bench marks were established. In addition, Mr. Flocker resurveyed 105 square miles of the Johnstown quadrangle.

Tennessee.-The survey of the Woodbury quadrangle, in Cannon, Wilson, Rutherford, and Dekalb counties, was completed by Oscar Jones. The area surveyed was 242 square miles, for publication on the scale of 1:62,500, with a contour interval of 50 feet. Messrs. Jones and Berry also commenced the survey of the Ducktown Special quadrangle, mapping 14 square miles in Polk County for publication on the scale of $1: 24,000$, with a contour interval of 20 feet. For the control of the Woodbury and Franklin quadrangles 73 miles 
of primary levels were run, and 15 permanent bench marks were established.

Virginia.-The survey of the Fort Monroe Special quadrangle, for publication on the scale of $1: 24,000$, with a contour interval of 10 feet, and of the Hampton quadrangle, for publication on the scale of $1: 62,500$, with a contour interval of 10 feet, was completed by Albert Pike, J. S. B. Daingerfield, and R. L. Harrison. The area surveyed was all in Elizabeth County. The mapping of the Natural Bridge quadrangle, in Botetourt and Rockbridge counties, was completed by Messrs. Pike and Harrison, Van H. Manning, W. H. S. Morey, and Fred Graff, jr., for publication on the scale of $1: 62,500$, with a contour interval of 50 feet. The total new area surveyed was 62 square miles on the $1: 24,000$ scale and 304 square miles on the 1: 62,500 scale, in connection with which 47 miles of primary levels were run and 25 permanent bench marks were established.

West Virginia.-The State geologist of West Virginia allotted $\$ 15,000$ for cooperative topographic surveys and the Director of the Federal Survey alloted an equal sum for the same purpose. The following quadrangles were completed: Kenna, in Jackson, Kanawha, Mason, Putnam, and Roane counties; Otter, in Braxton, Calhoun, Clay, Kanawha, and Roane counties; Parsons, in Preston, Randolph, and Tucker counties; Walton, in Clay, Roane, and Kanawha counties; Winfield, in Jackson, Mason, and Putnam counties; and, in addition, the West Virginia portion of the Athalia, Point Pleasant, Ravenswood, and Glenwood quadrangles, in Cabell, Mason, and Jackson counties. All the work in West Virginia was for publication on the scale of $1: 62,500$, with contour intervals of 20 and 50 feet, and was done by J. M. Whitman, J. R. Eakin, E. I. Ireland, J. I. Gayetty, C. F. Eberly, and R. H. Reineck. The total area mapped was 1,544 square miles, in connection with which 306 miles of levels were run and 85 permanent bench marks were established.

Wisconsin.-Portions of the Cross Plains, Sparta, and Winona quadrangles, in Dane, La Crosse, Monroe, Buffalo, and Trempeleau counties, were mapped by Robert Muldrow and A. T. Fowler, for publication on the scale of $1: 62,500$, with a contour interval of 20 feet. The total area mapped was 272 square miles, in connection with which 38 miles of primary levels were run and 15 permanent bench marks were established. For the revision of the Oconomowoc quadrangle 72 miles of primary levels were run and 15 permanent bench marks were established.

DRAINAGE SURVEYS IN MINNESOTA.

An appropriation of $\$ 15,000$ was made by Congress in the Indian act for the survey of the swamp areas in the ceded lands of the Chippewas in Red Lake County, Minn. This appropriation was to be 
expended under the Secretary of the Interior, who directed that this work be done by the Geological Survey. A. P. Meade was detailed for this purpose. Approximately 600 square miles were covered with a network of levels and the swamp area was thus mapped. In addition a line of precise levels, 71 miles in length, was run by C. H. Semper from Crookston northeastward. Sufficient data were obtained to make estimates in regard to the drainage of the Mud Lake district, and these data were assembled early in the winter by Messrs. Meade and W. C. Hall and were submitted as a report to Congress.

\section{OFFICE WORK.}

The drafting on the following sheets was completed:

Coalville, Ala.; Stilesboro, Ga.; Breese, Galatia, and Wheaton, Ill.; Waukegan, Ill.-Wis.; Waukee, Iowa; Georgetown, Lockport, and Morganfield, Ky.; Baton Rouge, La.; Lewiston, Me.; Laurel and Rockville, Md.; Pontiac and Rochester, Mich.; Florence, Miss.; Forsyth and Atlanta, Mo.; Hanover, N. H.-Vt.; Loon Lake and Potsdam, N. Y.; Goshen, N. Y.-N. J.; Port Jarvis, N. Y.-N. J.-Pa.; Beckford, Four Oaks, and Winton, N. C.; Kings Mountain, N. C.S. C.; Ashland, Bidwell, Chillicothe, Chagrin Falls, Columbus Grove, Deshler, Middletown, New London, Ravenna, St. Henry, Warren, Waverly, West Salem, and Youngstown, Ohio; Athalia, Point Pleasant, Glenwood, and Ravenswood, Ohio-W. Va.; Clarion, Linesville, Middletown, New Holland, Sewickley, and Warren, Pa.; Woodbury, Tenn.; Fort Monroe Special, Natural Bridge, and Hampton, Va.; Kenna, Otter, Parsons, Walton, and Winfield, W. Va.

The Calhoun, Ky., and the Jackson, Miss., sheets were completely redrawn and one-half of the Wilkesville, Ohio, quadrangle.

Progress was made in the drafting of the following sheets:

Tallula, Ill., 94 per cent; Opelika, Ala., 75 per cent; Cross Plains, Wis., 63 per cent; Sparta, Wis., and Wyandotte, Mo.-Ind. T., 55 per cent each; Wilkesville, Ohio, 50 per cent; Poland, Me., 45 per cent; Providence, Ky., Mount Airy, Md., and the Ducktown Special, Tenn., 40 per cent each; Leavenworth, Kans., 25 per cent; Ray, N. Dak., 13 per cent; and Columbus, Ga., 8 per cent; while drafting was commenced on the Cooperstown, N. Y., sheet.

\section{WESTERN DIVISION.}

FIELD WORK.

\section{SUMMARY.}

Under the combined allotments from the appropriations for topography and surveying forest reserves, topographic work was done during the year in Arizona, California, Colorado, Montana, Nevada, New Mexico, North Dakota, Oklahoma, Oregon, South Dakota, 
Texas, Utah, Washington, and Wyoming. This resulted in the completion of the survey of 26 quadrangles and 2 special areas, in the reconnaissance survey of two large areas, and in the partial survey of 9 quadrangles, 2 special areas, and 2 reconnaissance areas. The total new area surveyed was 18,827 square miles, the surveys of 3,224 square miles being for publication on the scale of $1: 62,500$; those of 6,793 square miles for publication on the scale of $1: 125,000$; and of 8,810 square miles for publication on special scales. In addition, 803 square miles were resurveyed, of which 28 were for publication on the scale of $1: 62,500 ; 772$ were for publication on the scale of $1: 125,000$; and 3 were for publication on the scale of $1: 6,000$. In connection with this work 2,471 miles of primary spirit levels and 311 miles of precise levels were run, and 737 permanent bench marks were established.

Topographic surveys in western division from May 1, 1906, to June 1, 190\%.

\begin{tabular}{|c|c|c|c|c|c|c|c|c|}
\hline \multirow{3}{*}{ State. } & \multirow{3}{*}{$\begin{array}{l}\text { Contour } \\
\text { interval. }\end{array}$} & \multicolumn{4}{|c|}{ Scale of publication. } & \multirow{3}{*}{$\begin{array}{c}\text { Total } \\
\text { area } \\
\text { sur- } \\
\text { veyed. }\end{array}$} & \multicolumn{2}{|c|}{ Levels. } \\
\hline & & \multicolumn{2}{|c|}{$1: 125,000$} & \multicolumn{2}{|c|}{$1: 62,500}$. & & \multirow{2}{*}{$\begin{array}{l}\text { Distance } \\
\text { run. }\end{array}$} & \multirow{2}{*}{$\begin{array}{l}\text { Bench } \\
\text { marks. }\end{array}$} \\
\hline & & New. & $\begin{array}{l}\text { Resur- } \\
\text { vey. }\end{array}$ & New. & $\begin{array}{l}\text { Resur- } \\
\text { vey. }\end{array}$ & & & \\
\hline & Feet. & Sq. miles. & Sq. miles. & Sq. miles. & Sq. miles. & Sq. miles. & Miles. & \\
\hline $\begin{array}{l}\text { Arizona .................. } \\
\text { Californiz............ }\end{array}$ & $\begin{array}{r}10-20 \\
5-50-100\end{array}$ & $\begin{array}{l}337 \\
969\end{array}$ & $\cdots . .$. & $\cdots \cdots$ & $\cdots \cdots{ }_{28}$ & $\begin{array}{r}a 340 \\
b c 4,433\end{array}$ & $\begin{array}{l}282 \\
757\end{array}$ & $\begin{array}{r}79 \\
172\end{array}$ \\
\hline Colorado ............ & $20-50-100$ & 681 & & 246 & & d1, 055 & 257 & 72 \\
\hline Montana...... & 100 & 507 & & 20 & $\ldots$ & $c 2,359$ & 103 & 22 \\
\hline Nevada .............. & $20-100$ & & & & & $b c 4,297$ & 259 & 57 \\
\hline New Mexico ......... & 100 & 713 & 60 & & .... & 773 & 406 & 124 \\
\hline North Dakota........ & $\begin{array}{r}100 \\
20\end{array}$ & $\cdots$ & & 1024 & $\cdots$ & $\begin{array}{c}c 35 \\
\end{array}$ & & \\
\hline $\begin{array}{l}\text { Oklahoma } . . . \ldots \ldots \\
\text { Oregon................. }\end{array}$ & $50-100$ & 984 & & 1,024 & & $\begin{array}{r}1,024 \\
984\end{array}$ & $\begin{array}{r}63 \\
160\end{array}$ & $\begin{array}{l}21 \\
41\end{array}$ \\
\hline South Dakota....... & 20 & & & 142 & & 142 & & \\
\hline Texas ...................... & $20-50$ & 629 & 87 & 677 & $\cdots$ & 1,393 & $\cdots$ & \\
\hline 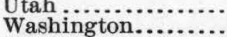 & $20-50$ & 1,060 & 625 & 197 & $\ldots$ & $\begin{array}{r}625 \\
1,257\end{array}$ & $\dddot{158}$ & 37 \\
\hline Wyoming .................. & 100 & 913 & & & & 913 & 337 & 112 \\
\hline Total.. & & 6,793 & 772 & 3,224 & 28 & 19,630 & 2,782 & 737 \\
\hline
\end{tabular}

a 3 square miles resurvey in Arizona for publication on the scale of $1: 6,000$.

b 26 square miles in California and 42 square miles in Nevada for publication on the scale of $1: 24,000$.

c 2,472 square miles in California, 1,852 square miles in Montana, 35 square miles in North Dakota, and 4,255 square miles in Nevada for publication on the scale of $1: 253,440$.

$d 128$ square miles in Colorado for publication on the scale of $1: 48,000$.

DETAILS OF TOPOGRAPHIC FIELD WORK, BY STATES.

Arizona.-A portion of the Tombstone Special area, consisting of 3 square miles in Cochise County, was resurveyed for publication on the scale of $1: 6,000$, with a contour interval of 10 feet, this work being done by E. R. Bartlett. A line of precise levels was run from Deming, N. Mex., to Tucson, Ariz., for the control of future work, a total distance of 225 miles, in connection with which 58 permanent bench marks were established. Of this line 143 miles, with 33 bench marks, were in Arizona, the rest being in New Mexico. In the Tonto National Forest the survey of the Four Peaks quadrangle, in Mari- 
copa and Gila counties, was completed by S. N. Stoner, for publication on the scale of $1: 125,000$, with a contour interval of 100 feet, the area mapped being 337 square miles. For the control of the Chiricahua National Forest 139 miles of primary levels were run by T. A. Green, in connection with which 46 permanent bench marks were established.

California.-The State Board of Examiners of California allotted $\$ 15,000$ for cooperative topographic surveys in California, and the Director of the Federal Survey allotted a like sum for the same purpose. In the Sacramento Valley the survey of the Elmira, Clarksburg, Rio Vista, and Montezuma quadrangles, in Solano, Yolo, Sacramento, Contra Costa, and San Joaquin counties, was completed by A. H. Sylvester, A. B. Searle, Arthur Stiles, W. R. McKean, E. P. Davis, and C. L. Nelson. The new area surveyed was 938 square miles, in addition to which revision surveys of 28 miles, on an enlarged scale, were made in the Carquinez and Napa quadrangles. This work was for publication on the scale of $1: 62,500$, with a contour interval of 5 feet. The survey of the Yosemite Special area, in Mariposa County, was completed by F. E. Matthes, for publication on the scale of $1: 24,000$, with a contour interval of 50 feet, the area surveyed being 26 square miles. For the control of the work in California 52 miles of primary levels were run and 13 permanent bench marks were established.

In cooperation with the State of California, the survey of the Kernville quadrangle, in Kern, Tulare, and Inyo counties, consisting of 969 square miles, in the Sierra National Forest, was completed by Arthur Stiles and George R. Davis, for publication on the scale of $1: 125,000$, with a contour interval of $100^{\circ}$ feet. In connection with this work 45 miles of primary levels were run and 16 permanent bench marks were established.

For the vertical control of the Trinity National Forest 203 miles of levels were run by L. F. Biggs, in connection with which 20 permanent bench marks were established.

Colorado.-The survey of the Loveland and Fort Collins quadrangles, consisting of 246 square miles, was completed for publication on the scale of $1: 62,500$, with a contour interval of 20 feet; also three-fourths of the Livermore quadrangle, 460 square miles, for publication on the scale of $1: 125,000$, with a contour interval of 100 feet. This work was done by Frank Tweedy. The survey of the Colorado Springs quadrangle, for publication on the scale of $1: 125,000$, with a contour interval of 100 feet, and of the Pikes Peak Special quadrangle, for publication on the scale of $1: 48,000$, with a contour interval of 50 feet, was commenced by Richard T. Evans, 221 square miles of the former and 128 square miles of the latter being completed. This work was all in El Paso and Teller counties. 
The total area mapped was 1,055 square miles, and for the control of this and adjoining areas 137 miles of levels were run and 36 permanent bench marks were established.

Colorado-New Mexico.-For the control of eight quadrangles from Durango southward through San Juan County, Colo., and Rio Arriba County, N. Mex., 444 miles of primary levels were run, in connection with which 135 permanent bench marks were established. Of this, 120 miles and 36 bench marks were in Colorado, the rest being in New Mexico.

Montana.-The mapping of the Sapphire quadrangle in the Hell Gate National Forest, in Granite County, was commenced by J. F. McBeth, for publication on the scale of $1: 125,000$, with a contour interval of 100 feet, the area mapped being 507 square miles. In connection with this work 103 miles of levels were run and 22 permanent bench marks were established.

Montana-North Dakota.-The survey for a reconnaissance map covering portions of Dawson County, Mont., and Billings County, N. Dak., was commenced by R. H. Chapman. The area mapped was 1,887 square miles, for publication on the scale of $1: 250,000$, with a contour interval of 50 feet, 35 square miles being in North Dakota.

Nevada.-The survey of the Ely Special area, in White Pine County, was completed by Fred McLaughlin, for publication on the scale of $1: 24,000$, with a contour interval of 20 feet, the area mapped being 42 square miles.

Nevada-Catifornia.-The survey of the Las Vegas and Furnace Creek quadrangles was completed by D. F. C. Moor and J. E. Blackburn, and Mr. Blackburn also mapped a portion of the Ballarat quadrangle. This work is for publication on the scale of $1: 250,000$, with a contour interval of 100 feet, 4,255 square miles being in Lincoln County, Nev., and 2,472 square miles in Inyo County, Cal. For the control of these areas 630 miles of primary levels were run, in connection with which 157 permanent bench marks were established, 371 miles of levels and 100 bench marks being in California and the rest in Nevada. For the control of future mapping a line of precise levels was run from Barstow to Mohave, 86 miles in length, in connection with which 23 permanent bench marks were established.

New Mexico.-The Gallina quadrangle, in the Jemes National Forest, in Rio Arriba and Sandoval counties, was partly surveyed by J. E. Blackburn and D. F. C. Moor, for publication on the scale of $1: 125,000$, with a contour interval of 100 feet. The area surveyed was 713 square miles.

Oklahoma.-The governor of Oklahoma allotted $\$ 5,000$ for the continuation of cooperative topographic surveys in Oklahoma and the Director of the Federal Survey allotted a like sum for the same purpose. The survey of the Agra, Euchee Creek, Shawnee, Maud, 
and Sac and Fox quadrangles was completed by H. H. Hodgeson, who also mapped portions of the Prague, Asher, and Luther quadrangles, all this work being for publication on the scale of $1: 62,500$, with a contour interval of 20 feet. The area mapped was 1,024 square miles, in Payne, Lincoln, and Pottawatomie counties. For the control of this and other areas 63 miles of primary levels were run and 21 permanent bench marks were established.

Oregon.-The State engineer of Oregon allotted $\$ 2,500$ for the continuation of cooperative topographic surveys in Oregon and the Director of the Federal Survey allotted a like sum for the same purpose. The survey of the Blalock Island quadrangle was completed by A. H. Sylvester and S. N. Stoner, for publication on the scale of 1:125,000, with a contour interval of 50 feet. The area surveyed was 835 square miles, 602 of which were in Gilliam and Morrow counties, Oreg., and 233 in Klickitat and Benton counties, Wash. For the control of this and adjacent areas 228 miles of levels were run and 60 permanent bench marks were established, 68 miles of levels and 19 bench marks being in Washington. The survey of the Mount Hood Special quadrangle, in the Bull Run National Forest, in Clackamas County, was commenced by S. N. Stoner, who surveyed 66 square miles, for publication on the scale of $1: 125,000$, with a contour interval of 100 feet. The survey of the Ironside Mountain quadrangle, in Baker, Malheur, Grant, and Harney counties, within the Blue Mountain National Forest, was completed by Mr. Stoner, 316 square miles being mapped for publication on the scale of $1: 125,000$, with a contour interval of 100 feet.

South Dakota.-The survey of the Two Top quadrangle, in Butte County, was completed by S. P. Floore, the area surveyed being 142 square miles, for publication on the scale of $1: 62,500$, with a contour interval of 20 feet.

Texas.-The survey of the Texarkana, Atlanta, Lindon, and Boston quadrangles, in Cass, Bowie, and Miller counties was completed by R. A. Farmer, for publication on the scale of $1: 62,500$, with a contour interval of 20 feet, the area surveyed being 677 square miles. The survey of the San Marcos quadrangle, in Hays, Guadalupe, Caldwell, and Gonzales counties was commenced by Fred McLaughlin and Arthur Stiles. The area surveyed was 566 square miles, for publication on the scale of $1: 125,000$, with a contour interval of 20 feet.

Texas-New Mexico.-The survey of the La Union quadrangle, in El Paso County, Tex., was commenced by Mr. McLaughlin, the area surveyed being 63 square miles. He also did a small amount of revision work on the Las Cruces and El Paso quadrangles, this area amounting to 147 square miles. The total area surveyed was 210 square miles, for publication on the scale of $1: 125,000$, with a contour

$28 \mathrm{gEOL}-07-4$ 
interval of 50 feet, 150 square miles being in Texas, 63 of which is new work, and 60 square miles in New Mexico.

Utah.-The survey of the Marsh Peak quadrangle, in the Uinta National Forest, was completed by A. E. Murlin, who also commenced the mapping of the Browns Park quadrangle, the total area mapped being 625 square miles, for publication on the scale of $1: 125,000$, with a contour interval of 100 feet. The work was all in Uinta County and was a resurvey of an area previously mapped.

Washington.-The survey of the Sumas quadrangle, in Whatcom County, was completed by Pearson Chapman and J. G. Hefty, for publication on the scale of $1: 62,500$, with a contour interval of 20 feet, the area surveyed being 197 square miles. The survey of the Zillah quadrangle, in Yakima and Klickitat counties, was completed by C. W. Sutton, for publication on the scale of $1: 125,000$, with a contour interval of 50 feet, the area surveyed being 827 square miles, in connection with which 90 miles of levels were run and 18 permanent bench marks were established.

Wyoming.-The survey of the Fremont Peak quadrangle, in the Yellowstone National Forest, Fremont County, was completed by T. M. Bannon and S. S. Stahl, for publication on the scale of $1: 125,000$, with a contour interval of 100 feet. For the control of this and adjacent areas 337 miles of primary levels were run and 112 permanent bench marks were established. The Medicine Bow quadrangle, in the Medicine Bow National Forest, Carbon County, was completed by S. S. Stahl, the area surveyed being 42 square miles, for publication on the scale of $1: 125,000$, with a contour interval of 100 feet.

OFFICE WORK.

The drafting of the following sheets was completed:

Clarksburg, Elmira, and Kernville, Cal.; Ely Special and Las Vegas, Nev.; Blalock Island, Oreg.-Wash.; Zillah and Sumas, Wash.; and Fremont Peak, Wyo.

The drafting of the plats of the boundaries of the following was completed:

Wind Cave National Park, S. Dak., and the Yosemite National Park, Cal.

Progress was made in the drafting of the following sheets: Agra, Okla., 85 per cent; Gallina, N. Mex., and Sapphire, Mont., 75 per cent; Montezuma, Cal., 70 per cent; Loveland, Fort Collins, and Livermore, Colo., Furnace Creek, Nev., Marsh Peak, Utah, Two Top, S. Dak., Texarkana and New Boston, Tex., 50 per cent; Rio Vista, Cal., 45 per cent; Yosemite Special, Cal., Pikes Peak Special, Colo., and Ironside Mountain, Oreg., 40 per cent; Glendive, Mont., 33 per cent; Mallon and Luther, Okla., 30 per cent; Ballarat, Nev., Colorado 
Springs, Colo., and Sac and Fox, Shawnee, and Maud, Okla., 25 per cent; Four Peaks, Ariz., 20 per cent; La Union, N. Mex., 17 per cent; Asher and Prague, Okla., 15 per cent; Browns Park, Utah, 14 per cent; El Paso, N. Mex., 11 per cent; and Las Cruces, N. Mex., 4 per cent.

\section{TRIANGULATION AND COMPUTING SECTION.}

\section{FIELD WORK.}

\section{EASTERN DIVISION.}

The primary control work done during the season by this division remained in charge of S. S. Gannett and under the general direction of H. M. Wilson.

Primary triangulation, primary traverse, and precise leveling were carried on at various times by 9 parties. This work was distributed over portions of 18 States-Alabama, Florida, Georgia, Illinois, Indiana, Kansas, Kentucky, Louisiana, Maine, Missouri, New Hampshire, North Carolina, Ohio, Pennsylvania, South Carolina, Vermont, Virginia, and West Virginia. The total area covered by this primary control was 14,600 square miles, of which 12,200 square miles were controlled by primary traverse. The result of this work was to make control available in fifty-five 15 -minute quadrangles and four 30-minute quadrangles. In the progress of this work 38 triangulation stations were permanently marked and their geodetic positions determined, and 3,084 miles of primary traverse and 1,255 miles of precise levels were run, in connection with which 403 permanent bench marks were established.

Alabama.-The control of the Coalville 15-minute quadrangle, in Shelby County, was completed by C. B. Kendall, who ran 30 miles of primary traverse.

Alabama-Georgia.-Control for the Columbus quadrangle, in Russell County, Ala., and Chattahoochee and Muscogee counties, Ga., was obtained by C. B. Kendall, who ran 54 miles of primary traverse.

Ftorida.--For the control of the soil survey of Jefferson County 230 miles of primary traverse were run by L. E. Tucker.

Georgia.--The Eatonton and Milledgeville quadrangles, in Greene, Morgan, Putnam, Taliaferro, Baldwin, and Hancock counties, were controlled by 176 miles of primary traverse run by Mr. Kendall. A line of precise levels 39 miles in length was run from Macon to Milledgeville by C. H. Semper.

Illinois.-In cooperation with the State, control for the Galatia, Thompsonville, Waukegan, Herrin, Murphysboro, Galena, and Apple River quadrangles, in Hamilton, Saline, Franklin, Williamson, Lake, Jackson, Perry, and Jo Daviess counties, was obtained by 398 miles of primary traverse run by L. E. Tucker. A line of precise levels 142 
miles in length was run by T. A. Green from Olney to Champaign through the counties of Champaign, Coles, Cumberland, Edgar, Jasper, Richland, and Vermilion. Another line of precise levels 71 miles in length was run by Mr. Green from Duquoin to Shawneetown through the counties of Franklin, Gallatin, Perry, and Saline.

Indiana.-The Bloomington, Saline City, and Terre Haute quadrangles, in Monroe, Morgan, Owen, Clay, Parke, and Vigo counties, were controlled by 225 miles of primary traverse run by J. R. Ellis. A line of precise levels 51 miles in length was run by C. H. Semper from Mitchell to Worthington.

Kentucky.-In cooperation with the, State, control for the Sadieville quadrangle, in Franklin and Owens counties; for the Monticello and Burnside quadrangles, in Wayne County; and for the Clay quadrangle, in Caldwell and Crittenden counties, was obtained by 217 miles of primary traverse run by J. R. Ellis. Control for the Hazard, Grundy, and Whitesburg 30-minute quadrangles, in Breathitt, Knott, and Pike counties, was obtained by means of triangulation. Six old stations and 8 new stations were permanently marked and occupied by E. L. McNair. A line of precise levels was run by C. H. Semper from Georgetown to Louisville, a distance of 77 miles; another line, 96 miles in length, was run by W. H. Monahan from Lexington to Jackson; and a line 14 miles in length was run by T. A. Green in Crittenden County, the latter line being based on the elevation at Shawneetown, Ill., determined earlier in the season by precise levels from Duquoin, Ill.

Louisiana.-Primary traverse control for the soil surveys in Winn Parish was obtained by L. E. Tucker by means of 156 miles of primary traverse, in addition to 163 miles of primary traverse which had previously been run for the control of the Winnfield 15-minute quadrangle. A precise-level line 34 miles in length was run by E. L. McNair from Colfax to Winnfield. In cooperation with the State 218 miles of primary traverse were run by Mr. Tucker through portions of Acadia, Iberia, Lafayette, St. Mary, St. Martin, and Vermilion counties, from Morgan City to Jennings. A line of precise levels 99 miles in length was run through the same area by $\mathrm{Mr}$. McNair, this line being based upon the tidal bench mark at Weeks Island and extended via Baldwin and Lafayette to Jennings.

Maine.-In cooperation with the State a line of precise levels 33 miles in length was run by N. A. Campbell from a tidal bench mark at Portland to Brunswick, and another line of precise levels, 42 miles in length, was run from Portland northwestward to the New Hampshire-Maine boundary line near Freedom.

Missouri-Kansas.-The Easton and Leavenworth 15-minute quadrangles were controlled by a line of primary traverse 106 miles in length, run by G. T. Hawkins. 
Missouri-Indian Territory.-The Wyandotte 30-minute quadrangle, in Cherokee Nation, Ind. T., and in McDonald and Newton counties, Mo., was controlled by Mr. Hawkins, who ran 72 miles of primary traverse.

New Hampshire-Vermont.-A line of precise levels 130 miles in length was extended by N. A. Campbell from the vicinity of Freedom, N. H., to Whiteriver Junction, Vt., passing through the counties of Belknap, Carroll, and Grafton, N. H., and Windsor, Vt.

Ohio.-In cooperation with the State twelve 15-minute quadrangles, covering portions of the counties of Hocking, Jackson, Vinton, Fairfield, Pickaway, Carroll, Coshocton, Holmes, Tuscarawas, Wayne, Crawford, Huron, Richland, and Seneca, were controlled by 406 miles of primary traverse run by J. R. Ellis. A line of precise levels 50 miles in length was run by W. H. Monahan from Chillicothe to Portsmouth through the counties of Pike, Ross, and Scioto. Another line, 135 miles in length, was run by Mr. Monahan from Columbus eastward to Uhrichsville, through the counties of Fairfield, Guernsey, Muskingum, Perry, and Tuscarawas; and a third line, 89 miles in length, was run by C. H. Semper from Ottawa westward and northward to Defiance and thence eastward to Tontogany.

North Carolina-South Carolina.-Control for the Gaffney and Kings Mountain quadrangles, in Cleveland and Gaston counties, N. C., and Cherokee and York counties, S. C., was obtained by 135 miles of primary traverse run by C. B. Kendall.

Pennsylvania.-In cooperation with the State additional control for the Valier quadrangle, in Indiana and Jefferson counties, for the Arendtville, Newville, and Gettysburg quadrangles, in Adams and Cumberland counties, and for the Bedford quadrangle, in Bedford County, was obtained by G. T. Hawkins, who located 17 triangulation stations. The Butler and Zelionople quadrangles, in Butler County, were controlled by 108 miles of primary traverse run by C. B. Kendall.

Tennessee.-Control for the Woodbury, Franklin, and Jackson quadrangles, in Cannon, Rutherford, Williamson, Madison, Chester, Henderson, and Decatur counties, was obtained by Mr. Kendall, who ran 373 miles of primary traverse. A line of precise levels 58 miles in length was extended by T. A. Green from Nashville eastward through the Woodbury quadrangle.

Virginia.-The Buchanan and Fincastle quadrangles, in Botetourt and Rockbridge counties, were controlled by Oscar Jones, who located 4 triangulation stations. A line of precise levels 60 miles in length was run by N. A. Campbell from Buchanan northwestward along the Chesapeake and Ohio Railway to a point near Allegheny station.

West Virginia.-In cooperation with the State the control for the Elkins quadrangle, in Barbour and Randolph counties, was completed by E. L. McNair, who located 3 triangulation stations. 
WESTERN DIVISION.

Triangulation was carried on at various times during the year by 9 parties and primary traverse by 1 party, under the direction of E. M. Douglas. The work was distributed over portions of 9 States and Territories-Arizona, California, Colorado, Montana, New Mexico, Oklahoma, Oregon, Utah, and Washington. The total area covered by this primary control was 25,400 square miles, of which 250 square miles were controlled by primary traverse. The result of this work was to make control available in six 15-minute quadrangles, nineteen 30-minute quadrangles, and one special area. In the progress of this work 243 new triangulation stations were selected, permanently marked, and their geodetic positions determined, and 72 miles of primary traverse were run.

Arizona.-In order to control the Chiricahua National Forest triangulation was extended by T. M. Bannon over an area of 6,000 square miles in southeastern Arizona. In this work 48 points were located, in the counties of Cochise, Graham, Pima, and Santa Cruz.

California.-In cooperation with the State, four 15-minute quadrangles, in the counties of Contra Costa, Sacramento, Solano, San Joaquin, and Yolo, were controlled by C. F. Urquhart, who located 42 triangulation stations. Reconnaissance triangulation in the Trinity National Forest was extended by A. I. Oliver over an area of 1,000 square miles in Siskiyou and Trinity counties, but owing to extremely unfavorable weather, observations were not completed at the close of the season of 1906 .

Colorado.-The Eatonton quadrangle, in Larimer County, was controlled by Frank Tweedy, who located 6 triangulation stations. In connection with the extension of triangulation in Archuleta, Hinsdale, and La Plata counties, the control for the San Juan National Forest was completed by H. L. Baldwin, jr.

Colorado-New Mexico.-An area of 2,700 square miles in Archuleta, Hinsdale, and La Plata counties, Colo., and 3,200 square miles in Rio Arriba and San Juan counties, N. Mex., was controlled by 47 triangulation points located by H. L. Baldwin, who also furnished control for the Jemes and adjacent national forests.

Montana.-The Glendive one-degree quadrangle, mostly in Dawson County, Mont., but a small part in Billings and McKenzie counties, N. Dak., was controlled by 13 triangulation points located by R. H. Chapman.

Nevada.-Additional control for the Las Vegas one-degree quadrangle, in Lincoln County, was obtained by B. D. Stewart, who located 9 points by triangulation. The Ely Special area, in White Pine County, was controlled by Fred McLaughlin, who located 14 secondary triangulation points. 
Oklahoma.-In cooperation with the Territory, one 15-minute quadrangle, in Lincoln County, was controlled by locating 24 points by triangulation, and one quadrangle in Pottawatomie County was controlled by means of 72 miles of primary traverse. The field work was done by $\mathrm{H}$. H. Hodgeson.

Oregon.-In cooperation with the State the portion of the Blalock Island quadrangle that lies within Morrow County was controlled by 4 triangulation points located by C. F. Urquhart and A. I. Oliver. The Mount Hood Special area, in the Bull Run National Forest, was controlled by 9 triangulation points located by Mr. Urquhart.

Washington.-An area of 3,000 square miles in Benton, Franklin, Klickitat, and Wallawalla counties was controlled by means of 27 triangulation points located by Messrs. Urquhart and Oliver.

\section{OFFICE WORK.}

The office computations of triangulation, primary traverse, and adjustment of level circuits were continued in charge of S. S. Gannett until the reorganization of the topographic branch on March 19, when E. M. Douglas was placed in charge. The results of primary triangulation and primary traverse in 27 States were summarized and published in Bulletin No. 310. The triangulation and leveling plats of all States were brought up to date, as well as the card catalogue of triangulation and primary-traverse stations. The preparation of triangulation and leveling data for chiefs of field parties and in reply to requests of persons not connected with the Survey required the time of a considerable portion of the office force.

During the year the following results were computed by members of the topographic branch, detailed from time to time for office computing:

\section{EASTERN DIVISION.}

Alabama.-For the control of the Coalville quadrangle, in Shelby County, 370 latitudes and departures and 36 geographic positions were computed. Level circuits in the same area were adjusted. For that portion of the Columbus, Ga., quadrangle which lies within Russell County, Ala., 125 latitudes and departures and 23 geographic positions were computed.

Florida.-For the control of the soil survey map of Jefferson County, 930 latitudes and departures and 105 geographic positions were computed.

Georgia.-For the Columbus, Eatonton, Milledgeville, and portions of adjoining quadrangles, 1,530 latitudes and departures and 217 geographic positions were computed. The office computation of the precise-level line from Macon to Milledgeville was completed. 
Illinois.-Latitudes and departures to the number of 1,671 and 369 geographic positions were computed for the control of 7 quadrangles in the counties of Franklin, Hamilton, Saline, Williamson, Lake, Perry, and Jo Daviess. Level circuits in the same area were adjusted and the office computation of the precise-level lines Duquoin to Shawneetown and Olney to Champaign was completed.

Indiana.-For the Bloomington, Saline City, and Terre Haute quadrangles, in Monroe, Morgan, Clay, Owen, Parke, and Vigo counties, 1,229 latitudes and departures and 194 geographic positions were computed. The office reduction of the precise-level line Mitchell to Bedford was also made.

Kentucky.-The geodetic positions of 8 triangulation stations in Breathitt, Knott, and Pike counties, and 2,105 latitudes and departures and 160 geographic positions in Wayne, Franklin, Owen, Caldwell, and Crittenden counties were computed. Level circuits were adjusted in the Frankfort, Lockport, Burnside, Monticello, and Clay quadrangles. The office reduction of the precise-level lines from Georgetown to Louisville and from Lexington to Jackson was completed.

Louisiana.-For the Winnfield 15-minute quadrangle and for the remaining part of Winn Parish 2,092 latitudes and departures and 162 geographic positions were computed. Latitudes and departures to the number of 460 and 110 geographic positions in Acadia, Iberia, Lafayette, St. Mary, St. Martin, and Vermilion parishes were computed and office reduction of the precise-level line through the same parishes was made.

Maine.-The office reduction of the precise-level line in Cumberland and Oxford counties was made, and circuits of primary levels in the Lewiston and Poland quadrangles were adjusted.

Maryland:-Primary-level circuits were adjusted for Montgomery and Carroll counties.

Minnesota.-The office computation of the precise-level line in the ceded lands of the Chippewas, Red Lake County, was completed, and circuits of primary levels in the same area were adjusted.

Kansas-Missouri.-For the Leavenworth quadrangle, in Platte County, Mo., and Leavenworth County, Kans., and the Easton quadrangle, in Jefferson and Atchison counties, Kans., 580 latitudes and departures and 90 geographic positions were computed. Primarylevel circuits in the same area were adjusted.

Missouri-Kansas-Oklahoma.-Primary-level circuits in No. 2 County, Okla., Newton and McDonald counties, Mo., and Cherokee County, Kans., in the Wyandotte 30-minute quadrangle, were adjusted, and 690 latitudes and departures and 56 geographic positions were computed. 
New Hampshire-Vermont.-The office reduction was made of the precise-level line in Belknap, Carroll, and Grafton counties, N. H., and Windsor County, Vt. Primary-level circuits in the Winnepesaukee quadrangle, New Hampshire, were adjusted.

North Carolina-South Carolina.-Primary-level circuits were adjusted in the Gaffney and Kings Mountain quadrangles, and 1,060 latitudes and departures and 144 geographic positions, controlling these quadrangles, were computed.

Ohio.-For 12 quadrangles in the counties of Hocking, Jackson, Vinton, Fairfield, Pickaway, Carroll, Coshocton, Holmes, Stark, Tuscarawas, and Wayne, 2,044 latitudes and departures and 332 geographic positions were computed. The office reduction of the precise-level lines Chillicothe to Portsmouth, Columbus to Uhrichsville, and Ottawa to Tontogany was made, and primary-level circuits in the following counties were adjusted: Franklin, Fairfield, Ross, Pike, Scioto, Defiance, Henry, Lucas, Paulding, Harrison, Jefferson, Carroll, Columbiana, and Portage.

Pennsylvania.-The geodetic positions of 17 triangulation stations, 745 latitudes and departures, and 100 geographic positions of primary-traverse stations in Bedford, Butler, Adams, Cumberland, Indiana, and Jefferson counties were computed. Level circuits in parts of the same counties were adjusted.

Tennessee.-Computations of 2,481 latitudes and departures and 372 geographic positions were made in the Franklin, Jackson, and Woodbury quadrangles. The office reduction of the precise-level line Nashville to Woodbury was completed.

Virginia.-The geodetic positions of 4 triangulation stations in Botetourt and Rockbridge counties were computed, and the office reduction of the precise-level line Buchanan to Alleghany station was completed.

West Virginia.-The geodetic positions of 3 triangulation stations in Barbour and Randolph counties were computed, and primarylevel circuits in Mason, Jackson, Putnam, and Roane counties were adjusted.

\section{WESTERN DIVISION.}

Arizona.-The office reduction of the precise-level line from the Arizona-New Mexico line to Tucson was made, and all level circuits in the Territory were readjusted and the elevations of bench marks reduced to mean sea-level datum.

California.-The geodetic positions of 42 triangulation stations in Contra Costa, Sacramento, Solano, San Joaquin, and Yolo counties were computed. All circuits of levels in the State were adjusted, the elevations of bench marks were reduced to mean sea level, and the results were prepared for publication as a bulletin. 
Colorado.-The geodetic positions of 6 triangulation stations in Larimer County and of 18 stations in Archuleta, Hinsdale, and La Plata counties were computed, and level circuits in the same counties were adjusted.

Montana.-The geodetic positions of 12 triangulation stations in Dawson County were computed, and level circuits in Fergus County were adjusted.

New Mexico.-The geodetic positions of 26 triangulation stations in Rio Arriba and San Juan counties were computed, and level circuits in the same counties were adjusted. The office reduction of the precise-level line from Deming to the Arizona line was completed.

Nevada.-The geodetic positions of 14 secondary triangulation points in White Pine County were computed.

Oklahoma.-The geodetic positions of 15 triangulation points and the geographic positions of 63 primary-traverse points in Lincoln and Pottawatomie counties were computed, and primary-level circuits in the same counties were adjusted.

Oregon.-The geodetic positions of 9 triangulation stations controlling the Mount Hood Special quadrangle were computed.

Oregon-Washington.-The geodetic positions of 31 triangulation stations in Morrow County, Oreg., and Benton, Klickitat, Franklin, Yakima, and Wallawalla counties, Wash., were computed, and level circuits in the same area were adjusted.

Wyoming.-Level circuits throughout the State were readjusted, elevations of bench marks corrected to mean sea level, and the results arranged for publication.

SECTION OF INSPECTION OF TOPOGRAPHIC SURVEYING AND MAPPING.

During the field season inspection of topographic mapping, complete or in progress, was carried on by John H. Renshawe in the eastern part of the United States. The purpose of this work was the maintenance of uniformity of style and system in the expression of topographic features. All topographic parties in States east of Mississippi River were visited and given instruction.

During the office season careful attention was given to the final drawing of map sheets, for the purpose of eliminating personal characteristics and errors of expression. Attention was also given to the preparation of material for revision of the base map of the United States.

SECTION OF INSTRUMENTS AND TOPOGRAPHIC RECORDS.

During the year the usual custom of making a general overhauling of all instruments was continued. This work was done in the shop of the Survey, except when extensive repairs, beyond its capacity, 
were required, when the instruments were sent to the makers. Purchases were made from time to time to cover losses sustained by wear and tear in the field. Ten telescopic alidades, with special stadia attachment, were bought, as the experiments of the previous year proved that this attachment was most useful. Experiments were continued with solar alidades, with the view of adapting an instrument of this class to topographic work.

The filing of the original records under the existing card system was continued. The number of such pieces filed was about 1,500, comprising triangulation, level, and topographic notebooks and plane-table sheets. In addition, about 100 pieces of miscellaneous material were catalogued for filing.

\section{DIVISION OF GEOGRAPHY AND FORESTRY.}

The division was continued under the direction of Henry Gannett. The principal results were as follows:

The revision of the three-sheet map of the United States on a scale of $1: 2,500,000$ was continued and good progress was made.

The preparation of sheets, as part of the world-map scheme, on a scale of 1: 1,000,000 was continued. Seven such sheets have been projected, and all available surveyed material has been added to them. Separate maps of Wyoming, Utah, Colorado, Arizona, New Mexico, West Virginia, Virginia, Maryland, and Delaware have been drawn, embodying all available surveyed material.

Preparation of maps of the national forests has been continued in the form of township plats. These plats were at first made on a scale of 2 inches to the mile, and each township was published as an individual map. In order to meet better the needs of the Forest Service the scale was afterwards changed to 1 inch to the mile, and six townships are published together on an atlas sheet, on which is shown the land, timber, and alienation classification by color and by symbols. Additions to national forests which had been completed necessitated many changes in the manuscripts.

The preparation of "The areas of the United States, the States, and the Territories," published as Bulletin No. 302, which is the result of cooperation between the Census Office, the General Land Office, and the Geological Survey, is an attempt to bring the figures of areas into accord.

The "Manual of topographic methods" was prepared and published as Bulletin No. 307.

A list and descriptions of 100 atlas sheets illustrating topographic forms was prepared and published.

The preparation of gazetteers of New York and California was well advanced. 
Mr. Gannett continued as chairman of the Geographic Board. Much work was done for this organization in the preparation of lists of all towns in the United States where the post-office name differs from the town name-a matter that has been taken up with the Pôst-Office Department-and in the preparation of sheets showing different conventional symbols used by Government offices for the representation of the same object. An effort will be made to have one set of symbols adopted for Government use.

\section{CREDIT FOR SUGGESTIONS.}

During the fiscal year the following useful suggestions pertaining to topographic work were adopted with advantage to the Survey:

L. F. Biggs, levelman, suggested a useful method for checking rod readings, adapted to the yard rods used with precise-level lines, consisting of a series of graduations in feet on the back of the rods.

A. O. Burkland, assistant topographer, suggested a combination of the short-sight alidade with the ordinary boxwood plotting scale, the resulting device being a sight alidade at one-half the cost of the all-metal instrument and also a convenient plotting scale.

H. L. Baldwin, jr., topographer, proposed a plan whereby primary or secondary traverse lines could be plotted more accurately than by methods previously in use, the method being to plot the traverse on ten times the desired scale on a separate piece of paper placed near the proper place of the traverse on the map, and then to connect the terminal or controlling points of the large-scale traverse by a straight line which can be readily transferred to the proper place on the map by means of two triangles and at the same time reduced in length to its proper scale by dividing its length by ten.

Glenn S. Smith, topographer, proposed a movable arm for holding the compass on a traverse plane-table board, which permits easy adjustment for changed declinations.

\section{WATER-RESOURCES BRANCH.}

\section{ADMINISTRATION.}

During the last year some radical changes were made in the methods of carrying on the work and in the administration of the waterresources branch. The former "hydrographic" branch was composed of three divisions - the hydrographic, the hydrologic, and the hydroeconomic. The first named measured stream flow, the second investigated underground waters, and the third determined the quality of water, the variation that takes place in its constituents, and the effect of the variation on the usefulness of the water. These three divisions had many things in common, and there resulted some dupli- 
cation of work and more or less complication in administration. Therefore, at the beginning of the last fiscal year, these divisions were abolished and the common features of the work were consolidated, so that duplication would be avoided and the needs of one investigation be closely harmonized with those of another.

At the beginning of the last fiscal year it was necessary also to rearrange and reduce the work, because of the reduction in the appropriation made by Congress, which amounted to 25 per cent. After careful consideration, it was decided that instead of making a $\cdot$ uniform reduction along all lines of work, it would be better to study the needs or demands in each part of the country and reduce or discontinue in each region that work which seemed to be least important. It was clear, for example, that in the arid West the work of greatest importance is the measurement of stream flow for the determination of the amount of water available for irrigation; in the Mississippi Valley, broadly speaking, the work of greatest importance is the study of stream flow for purposes of flood control and navigation and the study of underground water and the determination of its quality; while in the eastern part of the United States the measurement of stream flow again assumes greatest importance.

The work was carried on under the direction of M. O. Leighton, acting chief hydrographer until February 1 and chief hydrographer thereafter, assisted by N. C. Grover, assistant chief hydrographer, until April 1, and by John C. Hoyt, assistant chief hydrographer, thereafter.

\section{STREAM-FLOW MEASUREMENTS.}

New York and New England district.-In this district there were 94 stream-measurement stations maintained, and, in addition, riverprofile surveys were made in cooperation with the State Survey Commission of Maine under the appropriation made by the legislature for this purpose. These surveys included the determination of the storage capacity available in the drainage basins of Wood and Attean ponds and Brassua Lake, and the area of Holeb, Long, Lower and Middle Roach, West Carry, and Spencer ponds and Flagstaff and Spring lakes. Profile surveys of Androscoggin River, which had been completed from tide water to Livermore Falls, were carried from Livermore Falls to Errol dam, at the outlet of Umbagog Lake. The amount appropriated by the State of Maine for the cooperative work was $\$ 3,500$.

A report on the hydrography of the Kennebec River basin, dealing with stream flow, quality of water, sewage pollution, water power, and water storage, was completed in the early part of the year and forwarded for publication. This will soon appear as 
Water-Supply and Irrigation Paper No. 198. The district was under the charge of $\mathrm{H}$. $\mathrm{K}$. Barrows.

The State engineer of New York, under authority granted by the legislature, cooperated in the maintenance of stream-measurement stations in New York to the extent of $\$ 1,500$. Assistance and advice were also received from the State water supply commission, the barge canal commission, and the additional water supply commission of the city of New York, for all of which it is desired to return acknowledgments.

Middle Atlantic States district.-This district covers Pennsylvania, New Jersey, Maryland, Virginia, and West Virginia. There were 61 stations maintained, but as most of them are well rated numerous visits thereto for the purpose of making measurements were not required, and the greater part of the work consisted of observation of gage heights. Beginning April 1, 1907, by reason of the great reduction made in the appropriation for the work of the branch, the expenses of maintenance of river stations in Pennsylvania, including the pay of gage readers and the traveling expenses of Survey engineers, were temporarily assumed by the State water supply commission of Pennsylvania, in the hope that later appropriations may be sufficient to enable the Federal Survey to resume its original work. The supervision of the work and the computations and office work necessary in connection with the publication of the results are to be maintained throughout the fiscal year by the Survey.

The work at the measurement stations maintained in Maryland, except a few in the upper Potomac basin, received the aid of the State geologist, who assumed the payment of gage readers. The work in this district was under the charge of N. C. Grover.

South Atlantic States district.-There were 118 flow-measurement stations maintained in this district, which covers all the Atlantic and Gulf States from North Carolina to Louisiana, inclusive, and also Tennessee. This is one of the most important stream-measurement districts in the country, and the industrial development along the rivers resulting from the work of the Geological Survey has been greater than in any other part of the United States except in the arid West. The work in this district was under the charge of M. R. Hall. .

Central States district.-Stream-flow measurements in the Central States were largely discontinued except in Michigan, Wisconsin, and Minnesota, because it was believed that greater benefit would be secured in the remaining States by the investigation of undergroundwater resources. In the three States mentioned 30 river stations were maintained. In addition, profile surveys were made in Wisconsin, in cooperation with the Geological and Natural History Survey of the State, L. S. Smith, engineer, under an appropriation of $\$ 2,500$ 
made by the legislature for that purpose. The stream-measurement work in this district was under the charge of Albert H. Horton.

Missouri River district.-This district comprises North Dakota, South Dakota, Montana, and northern Wyoming. There were 81 stations maintained, and the work was largely devoted to the measurement of streams available for irrigation. Cooperation was secured with the United States Reclamation Service in the maintenance of stations connected with irrigation projects actually under construction. The work in this district was under the charge of Robert Follansbee.

Nebraska.-The work in this State was carried on in cooperation with the State engineer, who performed all the field work necessary to maintain 10 stations. The expenses, exclusive of the services of the State engineer, were equitably divided.

Denver district.-This district comprises Colorado, southern Wyoming, and eastern Utah. Fifty-eight stations were maintained, largely to obtain data in connection with irrigation. The headwaters of many of the most important streams of the United States are located in this district, which makes it a critical point for the accurate observation of stream flow. The work in this district was under the charge of R. I. Meeker.

Texas.-In this State 27 stations were maintained. The work in Texas, having been carried on for an extended term of years, may be considered practically finished. The measurements have been made under the direction of T. U. Taylor.

New Mexico.-This district comprises New Mexico and Oklahoma. Twenty-seven stations were maintained, largely for purposes of irrigation. The United States Reclamation Service cooperated in the maintenance of measurement stations connected with projects under construction. The work in this district was directed by W. A. Lamb.

Great Basin district.-This district comprises.Idaho, Utah, and Nevada. Forty-one stations were maintained. The United States Reclamation Service cooperated in the maintenance of project stations in all three of these States, while additional cooperation was rendered by the State engineer of Nevada. The work in this district was under the charge of E. C. La Rue.

Columbia River district.-The possibilities of water-supply development in this district, which comprises Washington and Oregon, are not yet properly appreciated, and years must elapse before investigations can be carried sufficiently near to completion to show the enormous resources of this region. During the last fiscal year 28 measurement stations were maintained in Washington and 51 in Oregon, the work in the latter State being carried on in cooperation with the State engineer, to whom acknowledgment is made for excel- 
lent services. The Reclamation Service also cooperated in the maintenance of project stations. The work in this district was under the charge of J. C. Stevens.

California district.-The work in this district was carried on in cooperation with the State of California under a liberal appropriation made by the legislature in response to the demand of citizens of the State who realize that industrial development is largely dependent upon the proper examination of water resources. There were 70 stations maintained, and in addition observations and surveys were made looking to the diffusion of information concerning the conservation of water supplies. The work in this district was under the charge of W. B. Clapp.

The total number of stations maintained by the water-resources branch during the last fiscal year was 686 .

UNDERGROU ND-WATER INVESTIGATIONS.

Investigations of underground water comprise the geologic study of water-bearing strata, the depth at which they occur beneath the surface, the amount and character of water available and its usefulness in irrigation and for domestic and industrial supplies.

Maine, south of the forty-ninth parallel.-A study of the depth of currents and the amount and character of the deep-seated waters in the granite of the State was conducted by F. G. Clapp.

Connecticut.-A study of the underground waters, similar in all respects to that in Maine, was conducted by H. E. Gregory.

Coastal plain of Virginia and North Carolina.-A study of the artesian waters derived from the uplands of the Appalachian region and flowing beneath the surface at varying depths on the broad, low plain adjoining the coast was conducted by Samuel Sanford and Bertrand L. Johnson, under the direction of M. L. Fuller.

Blue-grass region of Kentucky.-A study of the upper and the deep-seated waters in the various formations in this region, the origin and immediate sources of which are obscure, was conducted by George C. Matson.

Iowa and southeastern Minnesota.-This study consisted of locating and exactly defining the sources of artesian water beneath this great area, former observations concerning which had been confusing. One of the most important features of this investigation was the study of the character of the water and its variation from month to month in the same well or series of wells. In heavily mineralized waters, such as occur in this region, the consistent study of these variations is highly important from all practical stand- 
points. This work was conducted under the direction of W. H. Norton, M. L. Fuller, and W. S. Hendrixson.

Sun River Valley of Montana.-A study of the very important artesian basin in the vicinity of Great Falls, Mont., was conducted by C. A. Fisher.

Beaver Valley, Utah.-A study of artesian waters in Beaver County, Utah, similar in many respects to that of Sun River Valley in Montana, was conducted by W. T. Lee.

Southern foothill belt of California.-This is an important agricultural region east of the southern coastal plain, in which a knowledge of the currents of underground waters for irrigation is most important. The work was conducted by W. C. Mendenhall.

Underground waters of Lake County, Oreg.-This work was conducted under the direction of W. C. Mendenhall.

Other areas.-Investigations similar to the above were carried on but not fully completed in the Triassic area of New York, New Jersey, and Pennsylvania; in the northern portion of Florida; in Ohio and Indiana; in the northeastern portion of Texas; and in the San Joaquin Valley of California.

In addition to the work mentioned in the foregoing paragraphs, reports of investigations were completed and forwarded for publication as follows:

Flowing wells in the southern peninsula of Michigan, by Frank Leverett.

Geology and water resources of the western Panhandle of Texas, by C. N. Gould.

Underground waters of the coastal plain of Texas, by T. U. Taylor.

Water resources of the Rio Grande Valley of New Mexico, by W. T. Lee.

The underflow of the South Platte Valley in Nebraska, by C. S. Slichter and H. C. Wolf.

Geology and water resources of Owens Valley, California, by W. T. Lee. Underground waters of western Tennessee and Kentucky, by L. C. Glenn. Underground-water resources of Mississippi, by A. F. Crider.

Preliminary report on the Roswell artesian area, New Mexico, by C. A. Fisher. Underground waters of Utah Lake and Jordan River valleys, by G. B. Richardson.

INVESTIGATIONS OF QUALITY OF WATER.

In making a study of water resources it is necessary to consider the character of the water, because its usefulness is directly dependent on the minerals it contains. A water used for irrigation should not contain an overabundance of salts, since an excess of these is a detriment to crops. The amount and character of suspended matter carried by waters used for irrigation are important, because in some regions the sediment is of value as a fertilizer. Suspended matter is also of prime importance in connection with navigation, because it 28 GEOL $-07-5$ 
must be considered in connection with questions of channel maintenance and silting, as well as with decisions as to channel capacity, slope, etc. The study of the quality of water is also of great importance in connection with its usefulness for manufactures and public supplies; and, in general, considerations of the character of water are in many cases more important than considerations of quantity.

For the purpose of determining in the most comprehensive way the character of the waters in various parts of the United States, especially surface waters, sampling stations have been established on the more important rivers of the country and the samples collected are sent daily from these points to the various laboratories maintained under the direction of the water-resources branch. At these laboratories the samples have been analyzed, and the records show the character of the water and its variation from day to day, giving valuable and necessary data concerning the practical usefulness of the water under observation. Laboratories have been maintained at Washington, D. C.; Norfolk, Va.; Athens, Ga.; and Iowa City, Iowa. To the authorities of the University of Georgia and the State University of Iowa acknowledgments are due for gratuitously providing suitable quarters for the establishment of the laboratories. Work of similar character has been performed, under cooperation with the State water survey, State geological survey, and State experiment station of Illinois, in the laboratory of the first-named survey at Urbana, Ill. Similar investigations have been made in cooperation with the State of Kansas and the State University of Kansas at Lawrence; also in cooperation with the State board of examiners of California, quarters for the laboratory having been furnished by the authorities of the University of California at Berkeley. This work has been under the general direction of R. B. Dole, assisted by H. N. Parker, W. D. Collins, Walton Van Winkle, Edward Bartow, and others.

In addition to the work above described, analyses have been made in connection with ground-water investigations. The samples collected are representative of conditions normally occurring in the various regions under investigation. From the results collected there will be prepared reports on the best methods of utilizing these waters. In connection with this work investigations have been made of the effects of certain wastes on the waters of the country and the damage caused by them. Such work has been carried on in cooperation with the Massachusetts Institute of Technology at Boston, - under the direction of Earle B. Phelps, and also in cooperation with the State board of health of Rhode Island, under the general direction of Herman Stabler. 


\section{TECHNOLOGIC BRANCH.}

ORGANIZATION.

The technologic branch includes the division of fuels and the division of structural materials.

The creation of this new branch did not involve any radical change of the organization that formerly existed in the fuel-testing plant and the structural-materials testing laboratories in Forest Park, St. Louis, Mo.

In pursuance of an order of the Secretary of the Interior, the technologic branch organized its administrative office in Washington, D. C., on April 2, 1907, the official headquarters of both divisions above named having before that time been at St. Louis. The permanent organization in Washington embraces the expert in charge, Joseph A. Holmes, the chief engineer, H. M. Wilson, who in the absence of the expert in charge assumes his duties, the editorial assistants, and the general clerical force engaged on the correspondence, records, supplies, shipments, accounts, and bibliography. From the Washington office directions are issued in respect to the investigations, tests, field work, and other operations of the officers and employees in different parts of the country.

\section{FUELS DIVISION.}

The investigations of the fuel resources of the United States and the analyzing and testing of the coals, lignites, peats, mineral oils, and other mineral fuels belonging to and for the use of the United States, in order to determine their fuel value, which were begun in 1904 under the authority of Congress, were continued during the year at the fuel-testing plant in St. Louis.

During March, April, May, and June of the present year, as the work of the various sections would permit, the boiler, producer, and briquetting sections of the fuel-testing plant were removed from St. Louis to Norfolk, Va., for testing coals for naval uses; the coking and coal-washing sections to Denver, Colo., for testing coals from the public lands; and the chemical laboratories to Pittsburg, Norfolk, Washington, and Denver, for the analysis of coals sent in from the different Government stations.

The work of the fuels division has been divided into sections, as follows:

\section{CHEMICAL SECTION.}

In this section are made all analyses and calorimetric determinations of fuels, samples of which are submitted therefor, including the analysis and laboratory testing of the coals used by the Government. This section also investigates the chemistry and physics of the com- 
bustion of fuels, the heating value of the various fuels and methods of determining the same, the by-products obtainable in the coking of coals, mainly from public lands of the West, the physical and chemical composition of the various fuels and of the products of combustion at various temperatures, and kindred problems. N. W. Lord, professor of metallurgy and mineralogy at Ohio State University, continued to direct the work of this section.

Laboratories were provided and equipped in St. Louis for the work of this section, and during the period covered by this report about 1,400 samples were received in the laboratory. Proximate analyses and determinations of sulphur were made upon all of them, and upon a large number of the samples ultimate analyses and determinations of the heating value were made. These tests, together with other analyses of special materials, involved more than 7,000 determinations.

In addition to the regular work on fuels, about 100 samples of pig iron from the cupola tests on cokes were analyzed for silicon, sulphur, and manganese, with a view to determining the influence of the coke made from coals owned by the Government on the quality of the pig iron.

Research analyses and high-temperature measurements of the products of combustion will be made at Norfolk. The principal laboratory for coal analyses and experimental work and for byproduct investigations has been established at Pittsburg. A small laboratory is maintained at Washington for sampling the coals purchased by the Government Departments in the city.

\section{STEAM-ENGINEERING SECTION.}

In this section are conducted investigations for determining the most efficient method of burning coal in the heating and power plants of the Government in different parts of the country, including investigations looking to the minimum production of smoke and comparative tests of various coals under similar and different types of boilers. L. P. Breckenridge, professor of mechanical engineering at the University of Illinois, continued to supervise the work of this section, W. T. Ray being in immediate charge as engineer of tests. The section operated during the preceding fiscal year two 210-horsepower boilers with different equipment for firing, etc., and conducted 118 boiler tests.

In April the equipment was removed from St. Louis to Norfolk, Va., for the purpose of making investigations in cooperation with the Navy and other Government Departments with coals from Appalachian regions, and also of testing coals in the form of briquettes as compared with run-of-mine coal for naval purposes. In conducting these tests at Norfolk an additional boiler of naval water-tube 
type and of 250 horsepower and two 300-horsepower turbo-generators have been procured and are being installed in connection with the other equipment of the section. Certain important investigations relating to combustion in locomotives have also been made under the direction of Prof. W. F. M. Goss, of Purdue University, the chief purpose of these investigations being to obtain information that will lead to the abatement of the smoke nuisance from locomotives in the city of Washington and elsewhere.

\section{GAS-PRODUCER SECTION.}

In this section are conducted investigations for the purpose of determining the practicability of utilizing in the gas producer the low-grade fuels of the country for power and light purposes and also comparative tests in respect to fuel efficiencies and values. R. H. Fernald, professor of mechanical engineering at Washington University, continued in immediate supervision of the section, with J. P. Quam as engineer of tests. This section is demonstrating that many low-grade fuels heretofore considered worthless can now be used commercially without smoke or dust.

In May and June the plant of this section was dismantled and moved to Norfolk, Va., where it is proposed to conduct investigations during the next fiscal year in conjunction with the naval authorities, and the equipment has been augmented by the addition of various smaller internal-combustion engines in which tests will be made of the relative efficiency of gasoline, kerosene, and similar fuels for use on naval vessels.

\section{INSPECTION AND SMOKE-ABATEMENT SECTION.}

This section has been in operation since October, 1906, and in it are conducted investigations in respect to the inspection, sampling, and testing of coals used by the Government at its various public buildings throughout the country, with a view to discovering methods for increased efficiency and smoke abatement; also investigations looking to the purchase of the Government coal supply upon suitable specifications. The work is under the direction of D. T. Randall. Since it was commenced 177 samples of coal from different Government buildings in Washington, D. C., and elsewhere and additional samples of coal from mines, collieries, etc., have been collected.

In conjunction with the inspection work above mentioned in Government buildings in various large cities throughout the country and as auxiliary to the work of the steam-engineering section, observations have been made in this section of various power, heating, and lighting plants in Baltimore, Buffalo, Chicago, Cincinnati, Cleveland, Detroit, Indianapolis, Louisville, New York, Philadelphia, Pittsburg, St. Louis, and Toledo, and data on the methods adopted in such cities for the abatement of smoke and the progress made 
therein have been obtained, as throwing light on the practicability of adopting better methods in Government power plants.

This section is also making investigations in relation to the storage of coals in large quantities, with a view to the needs of the Government.

\section{COKING AND WASHERY SECTIONS,}

The work of these sections during the last fiscal year was so intimately connected that a joint report is made on them. The coking section is under the direction of A. W. Belden, and the washery section under G. R. Delamater, with Richard Moldenke as consulting engineer. During the last fiscal year 96 cupola tests, 74 coking tests, and 27 washery tests were completed.

In June the plants of both of these sections were dismantled and removed to Denver, Colo., where they are being erected with a view to making investigations to determine the value of the coal on the public lands still belonging to the Government, the extent to which these coals may be suitable for coking and other purposes, and the extent to which they may be improved by some process of washing.

COAL WASTE AND MINE-EXPLOSIVES SECTION.

During the last fiscal year investigations of the unnecessary waste of coal in mining were undertaken by E. W. Parker, of the geologic branch. Data were obtained from numerous localities, and the work will be continued during the current fiscal year. The main purpose of these investigations is the prevention of waste in the utilization of the nation's fuel supplies.

Mr. Parker having withdrawn from the investigation on June 1, on account of pressure of other work, the administration of these investigations has been intrusted to J. Shober Burrows, in connection with his supervision of the mining and coal-sampling section.

The explosive investigations of this section are under the supervision of Clarence Hall and have for their purpose the prevention of waste and the loss of life caused by coal-mine explosions. This section is also testing the explosives for the Reclamation Service and the Isthmian Canal Commission.

\section{BRIQUETTE SECTION.}

In this section 116 investigations were conducted in making and testing briquettes from 30 varieties of coal and other fuels. The work was in immediate charge of C. T. Malcolmson.

In June the briquette plant at St. Louis was dismantled and shipped to Norfolk, Va., where it is proposed to conduct briquette 
investigations in respect to the coals of the Atlantic seaboard, with a view to determining the comparative efficiency of briquettes and runof-mine coal for naval purposes and for use in locomotives. It is also proposed to make numerous investigations in connection with the briquetting of the lignites and lignitic coals found on the lands still belonging to the Government in the Western States and at other points, and for this purpose the equipment has been augmented by the purchase of a large German machine especially adapted to briquetting lignites.

MINING AND COAL-SAMPLING SECTION.

This section collects samples of coal for chemical analysis and testing from the different portions of the various coal fields which belong to the Government or from which coal supplies are needed for Government purposes. It is under the supervision of J. Shober Burrows. The inspectors in this section also make investigations relative to the extent of unnecessary waste in the mining and handling of coal.

\section{STRUCTURAL-MATERIALS DIVISION.}

The investigations of structural materials belonging to and intended for the use of the United States, such as stones, clays, cements, etc., begun in 1905 under the authority of Congress, were continued during the last fiscal year at the structural-materials testing laboratories in Forest Park, St. Louis. These investigations were continued under the general supervision of J. A. Holmes, expert in charge of the technologic branch, and were directly in charge of Richard L. Humphrey, engineer in charge of the division.

The personnel of this division remained practically the same throughout the fiscal year, embracing a corps of competent engineers, chemists, geologists, and other necessary assistants. The entire force of the division, however, with few exceptions, was organized during the fiscal year.

The work of the division embraces investigations relating to constituent materials and physical qualities of cements, gravels, sands, and other materials used in concrete and reenforced concrete and various forms of building blocks; brick, terra cotta, and other clay products; stone; and other similar materials concerning which information is desired for Government purposes. The tests of these materials determine the adhesive, compressive, and tensile strength, the coefficient of elasticity, the porosity, and the fire-resisting, weathering, and other qualities. 
The following is a résumé of the operations of the division:

Summary of operations of structural-materials division.

Constituent-material test pieces (briquettes, transverse bars, cubes, and cylinders) made

The same tested. 11,200

Physical tests (specific gravity, weight, etc.) 13,100

Beam test pieces made

The same tested

2,100

Building-block test pieces made

1,000

The same tested

2,000

1,350

Chemical analyses and determinations made

500

Fire-resisting tests conducted

The structural-materials laboratories are equipped with four 200,000-pound and one 100,000-pound testing machines, and sixteen smaller pieces of apparatus of different kinds adapted to the different tests, with the auxiliary appliances, instruments, and laboratory equipment necessary for conducting the investigations. A 600,000 pound vertical screw testing machine is now ready to be installed, and preparations are being made for a 1,200,000-pound vertical testing machine; these and even larger machines being rendered necessary by modern construction methods employed under the Supervising Architect, the Isthmian Canal Commission, the Reclamation Service, and other Government bureaus. The needs of the Government service also require a considerable amount of field work in determining the nature and extent of the deposits of material to be tested from different parts of the country. All of this work is arranged on such a basis of cooperation with the ordnance-testing laboratory at Watertown, Mass., as to avoid duplication.

\section{PUBLICATION BRANCH.}

EDITORIAL DIVISION.

\section{SECTION OF TEXTS.}

There were engaged in the work of this section 5 persons all of the year and 1 other person until October 31. The force was somewhat less than during the preceding year, and the amount of work done was likewise less, viz:

Manuscript pages edited, 26,912. (last year, 35,131), consisting of 1 Director's annual report, parts of 2 mineral-resources annuals, 1 monograph, 5 professional papers, 28 bulletins, 35 water-supply papers, 11 geologic folios, and miscellaneous matter.

Proof read, final pages, 16,833 (last year, 17,936), consisting of 1 Director's annual report, 1 mineral-resources annual, 2 monographs, 
5 professional papers, 33 bulletins, 35 water-supply papers, 12 geologic folios, and miscellaneous matter. These publications required the handling of 7,112 galley proofs and 28,018 page proofs (handled last year, 7,861 galley proofs and 32,256 page proofs).

The indexes prepared covered 12,167 pages (last year, 15,034), for 1 Director's annual report, 1 mineral-resources annual, 2 monographs, 6 professional papers, 27 bulletins, and 30 water-supply papers.

In addition to the above-noted work on the regular series of publications, this section examined the copy and proofs of all account and record books and blanks, circulars, office cards, etc.

\section{SECTION OF GEOLOGIC MAPS.}

The progress made in folio publication was about the same as in the last few years. Although but 11 folios were completed and issued, 4 of these were of double size. The Bald Mountain-Dayton, Cloud Peak-Fort McKinney, and Lancaster-Mineral Point contain each maps of 2 adjoining quadrangles, while the Joplin Special comprises a double-sized map.

At the beginning of the year work was in progress on 7 folios, all of which have since been published, and 11 others were on file. During the year 9 folios were transmitted to the section for publication, and 11 (Nos. 140 to 150, inclusive), as listed in the following table, were completed and issued:

Geologic folios issued during the fiscal year ending June 30, 190\%.

\begin{tabular}{|c|c|c|c|c|c|c|c|}
\hline No. & Name of folio. & State. & Author. & $\begin{array}{l}\text { Limiting } \\
\text { meridians. }\end{array}$ & $\begin{array}{l}\text { Limiting } \\
\text { parallels. }\end{array}$ & Area. & Price. \\
\hline $14 C$ & $\begin{array}{l}\text { Milwa u kee } \\
\text { Special. }\end{array}$ & Wisconsin .... & Alden, W. C.. & $87^{\circ} 50^{\prime}-88^{\circ} 5^{\prime} \ldots$ & $42^{\circ} 54^{\prime}-43^{\circ} 9^{\prime} \ldots$ & $\begin{array}{l}\text { Sq. } \\
\text { miles. } \\
219\end{array}$ & $\begin{array}{r}\text { Cents. } \\
25\end{array}$ \\
\hline 141. & $\begin{array}{c}\text { Bald Moun- } \\
\text { tain-Dayton. }\end{array}$ & Wyoming .... & $\begin{array}{l}\text { Darton, N. H.; } \\
\text { Salisbury, } \\
\text { R. D }\end{array}$ & $107^{\circ}-108^{\circ} \ldots$ & $44^{\circ} 30^{\prime}-45^{\circ}$. & 1,699 & 25 \\
\hline 142 & $\begin{array}{l}\text { Cloud Peak- } \\
\text { F or t M c- } \\
\text { Kinney. }\end{array}$ & .....do... & do & $106^{\circ} 30^{\prime}-107^{\circ} 30^{\prime}$ & $44^{\circ}-44^{\circ} 30^{\prime}$ & 1,713 & 25 \\
\hline 143 & Nantahala.... & $\begin{array}{l}\text { North } \\
\text { lina, } \\
\text { nessee }\end{array}$ & Keith, A...... & $83^{\circ} 30^{\prime}-84^{\circ}$. & $35^{\circ}-35^{\circ} 30^{\prime}$. & 975 & 25 \\
\hline 144 & Amity ......... & Pennsylvania & Clapp, F. G... & $80^{\circ}-80^{\circ} 15^{\prime}$ & $40^{\circ}-40^{\circ} 15^{\prime}$ & 228 . & 25 \\
\hline 145 & $\begin{array}{l}\text { Lancaster- } \\
\text { M in e ral } \\
\text { Point. }\end{array}$ & $\begin{array}{l}\text { Wisconsin, } \\
\text { Iowa, Illi- } \\
\text { nois. }\end{array}$ & $\begin{array}{l}\text { Grant, U. S.; } \\
\text { Burchard, } \\
\text { E. F. }\end{array}$ & $90^{\circ}-91^{\circ} \ldots$ & $42^{\circ} 30^{\prime}-43^{\circ}$ & 1,756 & 25 \\
\hline $\begin{array}{l}146 \\
147\end{array}$ & Rogersville... & Pennsylvania & Clapp, F. G... & $80^{\circ} 15^{\prime}-80^{\circ} 30^{\prime} \ldots$ & $39^{\circ} 45^{\prime}-40^{\circ}$. & 229 & 25 \\
\hline 147 & Pisgah......... & $\begin{array}{l}\text { North Caro- } \\
\text { lina, South } \\
\text { Carolina. }\end{array}$ & Keith, A...... & $82^{\circ} 30^{\prime}-83^{\circ} \ldots \ldots$ & $35^{\circ}-35^{\circ} 30^{\prime}$ & 975 & 25 \\
\hline 148 & Joplin .......... & $\begin{array}{c}\mathrm{M} \text { i s s o u } \mathrm{ri} \\
\text { Kansas. }\end{array}$ & $\begin{array}{l}\text { Smith, W. S. } \\
\text { T.; Sieben- } \\
\text { thal, C. E. }\end{array}$ & $94^{\circ} 15^{\prime}-94^{\circ} 45^{\prime} \ldots$ & $37^{\circ}-37^{\circ} 15^{\prime}$. & 476 & 50 \\
\hline 149 & $\begin{array}{l}\text { Penobseot } \\
\text { Bay. }\end{array}$ & Maine .......... & $\begin{array}{l}\text { Smith, G. O.; } \\
\text { Bastin, E. } \\
\text { S.; Brown, } \\
\text { C. W. }\end{array}$ & $68^{\circ} 30^{\prime}-69^{\circ}$. & $44^{\circ}-44^{\circ} 30^{\prime} \ldots \ldots$ & 857 & 25 \\
\hline 150 & Devils Tower. & Wyoming .... & $\begin{array}{l}\text { Darton, N. H.: } \\
\text { O'Harra, C. } \\
\text { C. }\end{array}$ & $104^{\circ} 30^{\prime}-105^{\circ} \ldots$ & $44^{\circ} 30^{\prime}-45^{\circ} \ldots$ & 849 & 25 \\
\hline
\end{tabular}


On June 30, 1907, 11 folios were in process of engraving and 4 were on file awaiting publication. The following geologic folios were in progress of engraving June 30, 1907: Ann Arbor, Mich.; Elk Point, S. Dak.-Nebr.-Iowa; Independence, Kans.; Ouray, Colo.; Passaic, N. J.-N. Y.; Patuxent, Md.-D. C.; Roan Mountain, N. C.-Tenn.; Winslow, Ark.; Rockland, Me.; Santa Cruz, Cal.; and Watkins Glen-Catatonk, N. Y.

The following folios awaited engraving on June 30, 1907: Aberdeen-Redfield, S. Dak. (comprises 4 quadrangles) ; Accident-Grantsville, Md.-W. Va.-Pa. (comprises 2 quadrangles); Belle Fourche, S. Dak.; Philadelphia Special, Pa.-N. J. (comprises 4 quadrangles).

\section{SECTION OF TOPOGRAPHIC MAPS.}

A year ago the editor of topographic maps reported 68 atlas sheets in manuscript awaiting editorial examination. The accessions since that date number 88 , making a total of 156 . Of these, 103 have been edited and approved during the year, leaving 53 now in hand. In the editor's custody on June 30,1907, there were 69 atlas sheets and special maps intended for publication but not yet given to the engravers; 16 of these had been edited and approved.

Against 115 topographic maps in hand for publication July 1, 1906, there were on June 30, 1907, 103-34 of them in process of engraving. Of those in hand July 1, 1906, 16 were still unpublished, though their engraving was well advanced. The number of new maps published during the year was 100 .

Corrections to 152 atlas sheets and special maps were edited and prepared for engraving. The corrections to 11 of these maps were extensive, and they were reissued with new edition dates. The number reissued as reprints was 253 .

The manuscript map illustrations for 37 volumes---bulletins, professional papers, water-supply papers, and an annual report-were examined and the geographic names verified or corrected. There were 362 of these maps.

The method of reproducing the index maps for the 20 mailing circulars $9-323$ was changed during the year. This necessitated new copy on an enlarged scale-two plates for each of the 20 circulars. These copies were prepared in this section, and occupied the time of one man during several months.

Most of the proof readers' time was devoted to the engravers' proofs of the 100 new sheets engraved and published during the year. The engraving of the corrections to the 152 maps above noted was verified by them, and other miscellaneous proof reading was done. 
SECTION OF DISTRIBUTION.

There were delivered to this section during the year 177 new documents, 109 new maps, and 255 reprints of maps, a total of 541 . They were: Twenty-seventh Annual Report; Monograph L; Professional Papers Nos. 46, 50, 51, 52, 54, 55, 57; Bulletins Nos. 275, 277, 279, 282 to 287,289 to 303,305 to $308,310,312,314,315$; Water-Supply and Irrigation Papers Nos. 155, 156, 158 to 164, 170, 172 to 194, 196, 200 ; Mineral Resources of the United States, 1905; Geologic Folios Nos. 136 to 149 ; 83 separates (50 from Mineral Resources, 1905; 12 each from Bulletins 285 and 314, and 19 from Bulletin 315), and 364 maps; the totals of all editions being 416,641 documents, 51,024 folios, and 779,021 maps; grand total, 1,246,686.

During the year 331,226 volumes, 48,944 folios, and 595,915 maps, a total of 976,085 , were sent out.

The total amount received and turned into the Treasury as a result of sales of publications was $\$ 18,633.31$, an increase of $\$ 998.52$ over the amount received during the year 190ら-6.

During the year 83,880 letters were received, answered, and filed, being 4,904 more than for the preceding year.

\section{DIVISION OF ENGRAVING AND PRINTING.}

There were on hand for publication July 1, 1906, 115 atlas sheets and other maps, of which 32 were partly engraved. During the year 88 new sheets were added, making a total of 203 . The status of these 203 sheets on June 30, 1907, was as follows:

Published during the year or in press at its close (double sheets counted as one) 100

In process of engraving

Not taken up_-_-_- 69

At the close of the year, therefore, the number of atlas sheets and other maps available for publication was 103. The corresponding figures for July 1 of each of the last five years are: 1902, 166; 1903, $156 ; 1904,127 ; 1905,126 ; 1906,115$-figures which show that the arrears of engraving have been reduced at the rate of 12 sheets a year during the last five years and that the engraving is now nearly if not quite on a current-work basis.

As shown above, 100 new topographic maps were engraved. In addition to this, corrections, some of them very extensive, were made on the plates of 152 maps. Editions of 364 topographic maps were printed and delivered. Of these, 100 were the new maps noted above, 11 were old maps reissued with new edition dates, and 253 were reprints.

Eleven geologic folios were published, and upward of 45,000 copies printed and delivered. Eight of these folios were reported partly 
finished last year. The number in hand partly completed at the close of the year was 10 .

Of miscellaneous matter of all kinds, the total number of copies printed was nearly a million and required about twice as many printings. The total number of copies printed of maps, folios, and miscellaneous matter was $1,752,508$, requiring over seven million impressions. There were also 361 transfer impressions made and sent to contracting printers.

The work of the photolithographic branch very largely increased. Photolithographs were made of 48 atlas sheets as soon as the manuscripts were completed, and small preliminary office editions printed. About 2,500 other maps were photolithographed for the Reclamation Service, the topographic, water-resources, and other branches of the Survey. The photolithographic processes are much employed in the compilation of maps, and assembling the parts of maps from field sheets. For this purpose celluloid prints of 142 maps or parts of maps were made.

A new method was introduced for the photomechanical transfer of a drawing to the copperplate for the guidance of the engraver. Credit for the development of this method is due to Andrew H. Linsenmeyer, a photolithographer of the engraving division.

\section{INSTRUMENT SHOP.}

The work of the instrument shop consisted in overhauling and repairing surveying, drafting, and engraving instruments, and in making copperplates and electrotypes. More than 1,600 repairs were made to instruments, and 296 new copperplates and 32 electrotypes were finished.

\section{SECTION OF GRAPHIC ILLUSTRATIONS.}

The number and kinds of illustrations prepared were: Maps, 350; sections and diagrams, 764; paleontologic drawings, 1,925; photographs retouched, 399; landscapes, 2; miscellaneous, 192; total, 3,632 .

The falling off in the total number of illustrations prepared during the year was due to a reduction in the number of illustrations of a photographic nature submitted with reports. $\mathrm{By}$ a reduction of such illustrations the tendency is to increase the amount of drafting, so that a larger number of drawings than formerly were prepared for direct reproduction.

Illustrations to accompany 61 publications were transmitted, viz, 32 water-supply papers, 23 bulletins, 5 professional papers, and the annual report.

At the close of the year material for illustrations of 15 reports was in hand, a part of which had already been prepared. 
Proofs to the number of 2,584 were received and examined critically. On account of inferior work by contractors during the last year the amount of proof reading was increased. In the majority of cases new proofs were requested, and in many instances reengraving was ordered.

During the year 226 electrotypes were furnished to applicants not connected with the Survey, and 335 cuts from the collection filed in this office were reused in the reports.

\section{PHOTOGRAPHIC LABORATORY.}

The output of the laboratory included 11,347 negatives, of which 9,535 were glass and 1,812 were paper; 50,265 prints, of which 17,531 were map prints and 32,734 were mat prints; and 1,605 lantern slides.

The proposed change from wet plates to collodion emulsion was not made owing to pressure of work and the lack of necessary room to continue the experiments. This change will be made as soon as the results of experiments now in progress will warrant.

During the year a complete cost-keeping system was installed.

The work of mounting the 6,000 photographs for the geologic type collection was completed in December, and the typewriting of the descriptions was well advanced. When completed this collection will form a valuable addition to the Survey library, its arrangement affording instant access to photographs descriptive of different geologic phenomena. It is at present in shape for reference, but many of the titles are incomplete. These will be completed as rapidly as the necessary information can be obtained.

\section{ADMINISTRATIVE BRANCH.}

EXECUTIVE DIVISION.

CORRESPONDENCE, RECORDS, APPOINTMENTS, SUPPLIES, AND SHIPMENTS.

On account of the organization of the Reclamation Service as a separate bureau, the total amount of work performed in this section was not so great as that for the fiscal year ending June 30, 1906.

Mails, files, and records.-There were received during the year 102,400 pieces of first-class mail. Of this number 18,075 contained money remittances for sale publications of the Survey. The recording and filing of correspondence required the services throughout the year of two clerks.

Appointments, attendance, etc.-In the roster of Secretarial appointments 1,002 changes were made-more than during any previous year for the Survey alone, and nearly as many as during $1905-6$, when the Reclamation Service was associated with the Survey and its large force was being rapidly built up. Of the 1,002 changes, 211 were appointments, 362 were promotions, 13 were reductions, and 116 were 
separations and revocations. The others included such formal and minor changes as removals of probationary limitations, extensions of temporary appointments, designations of disbursing agents, etc.

There are now on the regular rolls of the Survey 652 names.

There were recorded and granted 10,500 days of annual leave, 2,216 of sick leave, being 65 per cent of the amount of annual leave and less than 14 per cent of the amount of sick leave authorized by law; also 2,618 days of leave without pay.

Property accountability.- The system of property accounting, which in previous fiscal years employed one custodian or property clerk, was changed early in the year by the appointment, by the Secretary of the Interior, of a custodian for each branch or division. Thus this section was relieved of the preparation of property returns.

The amount of money derived from the sale at public auction of property examined by inspectors and found unserviceable was $\$ 2,946.29$. During the preceding fiscal year it was $\$ 4,667.58$.

Purchase and distribution of supplies.-The work of this sort performed during the year may be summarized as follows: Applications to the Secretary of the Interior for authority to purchase, 259; requisitions drawn on the Department for miscellaneous supplies, 536 ; orders drawn on dealers and others, 2,265 . The present system concentrates in this section all operations connected with purchases in Washington.

Express, freight, and registered mail.-During the year there were handled by the shipping clerk 5,569 pieces of express and freight, of which 1,683 were outgoing and 3,886 incoming; and 16,702 pieces of registered mail were handled, of which 13,974 were forwarded and 2,728 received. During the year 555 transportation accounts were checked by the shipping clerk.

Stationery.-In the stationery room the services of two men are required for handling mails, delivering supplies throughout the office, and wrapping and shipping them to the field parties. During the year 8,394 requisitions for blanks, blank books, and miscellaneous supplies were filled, and 625 requisitions were drawn on the Department.

Administrative bookkeeper.-The most important change in this section during the year was the appointment of an administrative bookkeeper, whose duty it is to keep the accounts of the expenses of the executive division and of supplies furnished the various divisions.

\section{DIVISION OF DISBURSEMENTS AND ACCOUNTS.}

A condensed statement covering the financial transactions of the fiscal year is given below. Only the net expenditures are shown therein, credits for services and materials furnished other Departments and Bureaus having been deducted. 
FINANCIAL STATEMENT.

Amounts appropriated for and expended by the United States Geological Survey for the fiscal year ending June 30, 190\%.

\begin{tabular}{|c|c|c|c|c|c|c|c|}
\hline & $\begin{array}{l}\text { Geological } \\
\text { survey, } 1907 .\end{array}$ & \begin{tabular}{|c|} 
Geological \\
survey, \\
1906-7.
\end{tabular} & $\begin{array}{c}\text { Geological } \\
\text { maps U. S., } \\
\text { 1907. }\end{array}$ & \begin{tabular}{c|} 
Surveying \\
forest re- \\
serves, 1907.
\end{tabular} & Testing fuel. & $\begin{array}{c}\text { Testing struc- } \\
\text { tural mate- } \\
\text { rials. }\end{array}$ & Total. \\
\hline 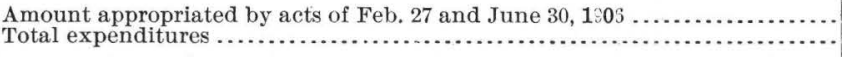 & $\$ 912,020.00$ & $\begin{array}{r}\$ 80,000.00 \\
78,865.01\end{array}$ & $\begin{array}{r}\$ 100,000.00 \\
94,391,20\end{array}$ & $\begin{array}{r}\$ 100,000.00 \\
86,715.18\end{array}$ & $\begin{array}{r}\$ 250,000.00 \\
241,4 \dot{b} 7.81\end{array}$ & $\begin{array}{r}\$ 100,000.00 \\
94,728.83\end{array}$ & $\begin{array}{r}\$ 1,542,020.00 \\
1,454,068.66\end{array}$ \\
\hline Balance unexpended June 30,1907 , available to meet outstanding liabilities.. & $54,119.37$ & $1,134.99$ & $5,608.80$ & $13,284.82$ & $8,532.19$ & $5,271.17$ & $87,951.34$ \\
\hline
\end{tabular}

Distribution of disbursements, Geological Survey, 190\%.

Salaries, Office of the Director

$\$ 34,980.35$

Salaries of scientific assistants

Skilled laborers, etc.

$19,999.72$

Topographic surveys

$19,905.51$

Geologic surveys.

$189,709.99$

Mineral resources U.

$70,168.19$

Gaging streams, etc.

8.

Paleontolooic surveys

Chemical and physical researche

$137,366,6$

Preparation of illustrations ......

Books for the library

$19,941.47$

$17,630.16$

$1,327.43$ 


\section{LIBRARY.}

Periodicals.-About 300 periodical publications are regularly received and recorded on cards. Completed volumes are bound and then entered in the accession book.

Books accessioned.-There were entered in the accession book, in which is kept the complete record of books permanently added to the library, 2,731 books, making the total number of books entered 64,078 .

Cataloguing.-During the year the work of cataloguing the publications of the various national surveys, the Canadian Geological Survey, and the various State geological surveys was completed and cards were printed by the Library of Congress. All separate works on mineralogy and petrology and text-books and general works on the geology of North and South America and of Great Britain have been catalogued. In economic geology the reports of foreign and State mining bureaus and text-books and general papers on mining and metallurgy were catalogued. Material received during the year was catalogued as received, except small and unimportant pamphlets.

Map cataloguing.-In cataloguing the publications of various geological surveys it was found necessary to catalogue a considerable number of maps. A card catalogue of maps was begun, arranged by countries and States or provinces, and it now contains approximately 1,000 cards.

Shelf listing.-Some difficulty having been experienced in finding books classified by subjects, it was determined to devote all the time possible to shelf listing the books and using the cards as temporary catalogue cards. All books on geology, paleontology, geography, mathematics, geodesy, astronomy, surveying, and engineering, not heretofore catalogued, have been shelf listed. These number 4,435.

New equipment.-Six steel pamphlet cases (four octavo and two quarto size) were installed, also one steel card cabinet case to hold the author and subject card catalogues. This completes the equipment purchased under the special appropriation of $\$ 7,000$.

Foreign and domestic exchanges.-All the book publications are regularly sent to 750 institutions and individuals, and from them are received a considerable part of the additions to the library. About 450 sets of map publications are also distributed to exchanges.

Bibliographic work.-The annual bibliography and index of North American geology, paleontology, petrology, and mineralogy for 1905 was completed, combined with the bibliographies for 1901 to 1904, and published as Bulletin No. 301. 


\section{INDEX.}

A.

Adirondacks, geologic work in, allotment to

Administrative branch, improvements in..

organization of.

work of.

Alabama, Bessemer quadrangle, work in....

Birmingham quadrangle, work in......

Coalville quadrangle, work in.. $13,32,39,45,49$

Columbus quadrangle, work in ....... 45, 49 geologic work in ..................... 13

Leeds quadrangle, work in ............ 13

Opelika quadrangle, work in ......... 32,39 topographic work in ............ $30,32,45,49$

Alaska, Berners Bay district, work in...... 24

Birch Creek district, work in.......... 24

Controller Bay region, work in........ 25

Cook Inlet region, work in ........... 25

Fairbanks region, work in ............. 24

Prince William Sound region, work in... 24

Rampart district, work in ............ 24

Seward Peninsula, work in........ 24,25-26

southeastern district, work in ......... 24

surveys in, progress of ........... 4-5,23-26

Yakutat-Alsek region, work in....... 24-25

Yukon district, work in......... 23-24,26

Alaskan mineral resources, division of, field work of. $22-26$

division of, personnel of ............. 22

Appalachians, geologic work in........... 11-13 geologic work in, allotment to......... 9

Appropriations, statement concerning..... 1

A rizona, Chiricahua National Forest, work in......................... 41, 48

Four Peaks quadrangle, work in... 40-41, 45 geologic work in. .................. 17, 18

allotment to.

8

map of, preparation of................ 53

Tombstone district, work in.......... 17, 40 topographic work in........... 30,40-41, 48, 51

Arkansas, cooperation with.............. 15

Eureka Springs quadrangle, work in.... 14

geologic work in ................... 14-15

allotment to.................... 8

Harrison quadrangle, work in......... 14

topographic work in .................. 30

Atlantic Coastal Plain, geologic work in.... 10 geologic work in, allotment to.......... 9

Atlantic States, water investigations in... 56

\section{B.}

Black sands, work on .....................

Briquette section, work of $64-65$
C.

Page.

California, Carquinez quadrangle, work in.. $\quad 41$

Clarksburg quadrangle. work in ........ 41, 44

cooperation with ............... 41; 48,60

Elmira quadrangle, work in ......... 41,44

gazetteer of ........................ 53

geologic work in . . ............... 17,18-19

allotment to ..................... 8

Kernville quadrangle, work in........ 41, 44

Montezuma quadrangle, work in...... 41,44

Napa quadrangle, work in............ 41

Redding quadrangle, work in......... 17

Rio Vista quadrangle, work in ........ 41,44

Santa Barbara County, work in....... 18-19

Shasta County, work in............... 17

Taylorsville quadrangle, work in...... 18

topographic work in....... 30, 40,41, $42,48,51$

Trinity National Forest, work in...... 41, 48

water investigations in.............. 58,59

Yosemite Special quadrangle, work in .. 41,44

Cataloguing, progress of................. 74

Central States, water investigations in..... $56-57$

Chemical and physical research, division of, work of . . . . . . . . . 27......... 29

Chemical section, work of............... 61-62

Clay, white, study of .................. 12

Coal, work on.......................... 24

work on, allotments to .............. $8-9$

See also Fuels division.

Coal fields, work on................ 12,14,15

Coal lands, survey of................... 4

Coal samples, collection of................ 65

Coal waste and mine explosive section, work of .......................... 64

Coking and washery section, work of........ 64

Colorado, Colorado Springs quadrangle, work in ................... 41,44-45

Eatonton quadrangle, work in........ 48

Fort Collins quadrangle, work in...... 41,44 geologic work in ................. 15-16,17 allotment to .................... 8,9

Ironside Mountain quadrangle, work in 44 Lake City quadrangle, work in ........ $\quad 16$

land classification in.................. 15

Leadville district, work in............ 17

Livermore quadrangle, work in ....... 41,44

Loveland quadrangle, work in . . ...... 41, 44

map of, preparation of................ 53

Pikes Peak special quadrangle, work in.. 41, 44

San Cristobal quadrangle, work in..... 16 topographic work in....... $30,40,41-42,48,52$ water investigations in ................ 57 
Columbia River district, water investigations in .................. 57-58

Congress, Tenth International Geological, meeting of ...................

Connecticut, topographic work in .......... water investigations in ................

Cooperation of States, details of............

Copper deposits, study of

D.

Delaware, geologic work in

topographic work in ..................

Wilmington quadrangle, work in.......

Denver district, water investigations in...

Director, field and office work of............

Disbursements and accounts, division of... 72-73

Distribution, section of, work of . .......... 69

District of Columbia, topographic work in.. 30

Drainage surveys, making of ............. 38-39

E.

Earthquakes, study of.................. 19,20

Engraving and printing, division of . ...... 69-70

Executive division, work of ............. 71-72

Exhibits, preparation of . ............... 21,27

F.

Finances, statement of ....................

Forestry. See Geography and forestry.

Florida, topographic work in ........... 30,45, 49

Folios, geologic, publication of .......... $67-68$

Fuels division, work of ................ 61-65

Fuel-testing plant, transfer of.............

61

G.

Gas-producer section, work of

Geochemistry, monograph on, completion

$$
\text { of } \ldots \ldots \ldots \ldots \ldots \ldots \ldots \ldots \ldots \ldots \ldots \ldots \ldots \ldots+27-28
$$

Geography and forestry, division of, work

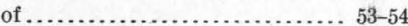

Geologic branch, organization of . . . . 2, 2, $3,6-7$

publications of .

Geologic maps, issue of .................. 67-68

Geological Congress, Tenth International, meeting of ...................

Geological Survey, growth of............... organization of

Geology and paleontology, division of, organization of .

division of, personnel of ..

work in, appropriations for, allotment of

classification of

distribution of .....................

Georgia, Columbus quadrangle, work in. .2

$39,45,49$

cooperation with...$\ldots \ldots \ldots \ldots \ldots \ldots .6 .60$

Dahlonega quadrangle, work in ....... 13

Eatonsville quadrangle, work in ...... 45, 49

geologic work in .................... 13

allotment to ...................... 9

Milledgeville quadrangle, work in..... 45, 49

Stilesboro quadrangle, work in ........ 32,39

topographic work in............ 30,32, 45, 49
Page.

Glacial phenomena, study of ............ 14,19

Granites, work on ..................... 10

Graphic illustrations, section of, work of... 70-71

Great Basin district, water investigations

in $\ldots \ldots \ldots \ldots \ldots \ldots \ldots \ldots \ldots . . .57$

Idaho, Coeur d'Alene district, work in .... $\quad 17$

geologic work in .................... 17, 19

topographic work in ................. $\quad 30$

water investigations in ............... 57

Illinois, Apple River quadrangle, work in .. $\quad 45$

Breese quadrangle, work in............ 33, 39

cooperation with . .............. $13,33,45,60$

Eldorado quadrangle, work in......... 13

Galatia quadrangle, work in ....... $33,39,45$

Galena quadrangle, work in ......... 45

geologic work in ..................... 13-14

allotment to .................... 8

Herrin quadrangle, work in .......... $\quad 45$

Lancaster-Mineral Point folio, publication of ...................... 67

New Haven quadrangle, work in ....... 13

St. Louis quadrangle, work in......... 13-14

Tallula quadrangle, work in.......... 33,39

Thompsonville quadrangle, work in.... 45 topographic work in........ 30,32, 33, 45-46, 50 Waukegan quadrangle, work in..... $33,39,45$

Wheaton quadrangle, work in......... 33,39

Indian Territory, geologic work in ........ geologic work in, allotment to......... 8 topographic work in..... 30,32,33,45, 46-47, 50 Wyandotte quadrangle, work in....... 14,

See also Oklahoma.

$33,39,46-47,50$

Indiana, Bloomington quadrangle, work in. 46, 50

Saline City quadrangle, work in..... 33, 46, 50

Terre Haute quadrangle, work in...... 46,50

topographic work in....... $30,32,33,45,46,50$

Inland Waterways Commission, importance of water-resources data to.......

Inspection and smoke abatement section, work of . ....................63-64

Instrument shop, work of ............... 70

Instruments and topographic records, section of, work of $\ldots \ldots \ldots \ldots \ldots .52-53$

Iowa, cooperation of..................... 60

geologic work in .................... 14

Lancaster-Mineral Point folio, publication of ........................ 67

topographic work in.............. 30,32,33

water investigations in .............. 58-59

Waukee quadrangle, work in.......... 33,39

Iron-ore deposits, study of .............. 14,16

$\mathrm{K}$.

Kansas, cooperation with................ 60

Easton quadrangle, work in .......... 46,50

geologic work in .................... 16

Joplin folio, publication of........... 67

Leavenworth quadrangle, work in. $33-34,39,50$

topographic work in..... $30,32,33-34,45,46,50$

Wyandotte quadrangle, work in....... 14

Kentucky, Burnside quadrangle, work in... 46

Calhoun quadrangle, work in.......... $\quad 39$

$\sqrt{2}$

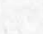

.

(2)


Page.

Kentucky, cooperation with...............

Clay quadrangle, work in.

geologic work in.

46

Georgetown quadrangle, work in

Grundy quadrangle, work in.......... 46

Hazard quadrangle, work in.......... 46

Kenova quadrangle, work in.......... 12

Lockport quadrangle, work in ........ 34, 39

Monticello quadrangle, work in........ 34, 46

Morganfield quadrangle, work in....... 34, 39

Providence quadrangle, work in....... 34,39

Sadieville quadrangle, work in........ 46

topographic work in ........ 30,32, 34, 45, 46,50

water investigations in .............. 58,59

Whiteburg quadrangle, work in ....... 46

\section{L.}

Library, work of ......................

Louisiana, Baton Rouge quadrangle, work

in .......................... 34,39

topographic work in........ $30,32,34,45,46,50$ Winnfield quadrangle, work in ..... $34,46,50$

M.

Magnesite, work in................... 18

Magnetite, work on..................... 12

Maine, cooperation of . ............... 10,34,55 geologic work in .................. 10

allotment to..................... 8

Lewiston quadrangle, work in...... 34, 39, 50

Penobscot Bay folio, publication of.... $\quad 67$

Poland quadrangle, work in ........... 39, 50 topographic work in ........ $30,32,34,45,46,50$ water investigations in ............. 55-56,58

Map, North America, preparation of..... 21-22 United States, preparation of ..........

Maps, cataloguing of..................... 74

preparation of...................... 53

publication of . ..................... 67-68

Maryland, cooperation with ............ 12,34, 56

Flintstone quadrangle, work in........ 12

Frederick quadrangle, work in ........ 34

Frostburg quadrangle, work in....... 12

geologic work in ..................... 11,12

allotment to..................... 9

Hancock quadrangle, work in ......... 12

Laurel quadrangle, work in.......... 34, 39

map of, preparation of .............. 53

Mount Airy quadrangle, work in...... 34, 39

Patuxent folio, completion of......... 11

Pawpaw quadrangle, work in........ 12

Rockville quadrangle, work in......... 34, 39

Tolchester quadrangle, work in........ 11

topographic work in ........... 30,32,34-35, 50

water investigations in .............. 56

Massachusetts, Blackstone quadrangle, work in.

geologic work in.

allotment to

Housatonic quadrangle, work in .......

Marlboro quadrangle, work in..........

Taconic quadrangle, work in..........

topographic work in.

Webster quadrangle, work in...

Worcester quadrangle, work in ......

Mereury, study of.
Page.

Metalliferous deposits, study of ........... 17-18

Metals, elasticity of, study of............ 28

Michigan, cooperation with.............. 35

geologic work in .................... 14

Pontiac quadrangle, work in.......... 35, 39

Rochester quadrangle, work in . . . . . . . 35, 39

topographic work in ................ 31,32,35

water investigations in ............. 56,59

Mine explosions, investigation of.......... 64

Minerals, identification of............... $\quad 27$

output of........................ 27

Mining and coal-sampling section, work of.. $\quad 65$

Mining and mineral resources, division of, work of . .................... 26-27

Minnesota, drainage surveys in . . . . . . . . . 38-39

geologic work in.................. 14

Rockford quadrangle, work in....... 35

topographic work in. ........... 31, 32, 35, 50

water investigations in........... 56, 57-58

Mississippi, Florence quadrangle, work in .. 35, 39

Jackson quadrangle, work in.......... 39

topographic work in............. 31, 32, 35

water investigations in ............... 59

Missouri, Atlanta quadrangle, work in . . . . 35, 39

Forsyth quadrangle, work in ......... 35, 39

geologic work in ................... 14

allotment to ..................... 8

Joplin folio, publication of............ 67

Leavenworth quadrangle, work in. 33-34, 46, 50

Macon quadrangle, work in......... $\quad 35$

topographic work in ................. 31 ,

$32,33-34,35,45,46-47,50$

Wyandotte quadrangle, work in ...... 14,

$33,39,46-47,50$

Missouri River district, water investigations in...................... 57

Molybdenum deposits, study of.......... 18

Molybdite, study of ..................... 28

Montana, geologic work in ............ 15, 16, 17

geologic work in, allotment to ......... 8

Glendive quadrangle, work in........ 44, 48

Philipsburg quadrangle, work in...... 16,17

Sapphire quadrangle, work in ........ 42,44 topographic work in ........... 31, 40, 42, 48, 52 water investigations in ............. 57,59

N.

National forests, maps of, preparation of., $\quad 53$

Nebraska, cooperation with.............. 57

topographic work in ................ 31

water investigations in . ............ 57,59

Nevada, Ballarat quadrangle, work in.... 44

Bullfrog district, work in............ 17

Ely Special quadrangle, work in..... $42,44,48$

Furnace Creek quadrangle, work in.... 42,44

geologic work in . . .................. 17, 19

Goldfield district, work in............ 17

Las Vegas quadrangle, work in . .... . 42, 44, 48

Manhattan district, work in.......... 17

topographic work in......... 31, 40, $42,48,52$

water investigations in .............. 57

New England, geologic work in.......... 10

water investigations in . .............. 55-56

New Hampshire, Hanover quadrangle, work in ....................... 35,39

Taconic quadrangle, work in......... 10 
Page.

New Hampshire, topographic work in..... 22, $31,35,45,47,51$

Winnepesaukee quadrangle, work in... 51

New Jersey, Franklin Furnace quadrangle, work in .....................

geologic work in .....................

allotment to.......................

Goshen quadrangle, work in

Greenwood Lake quadrangle, work in. .

Passaic quadrangle, work in...........

Philadelphia folio, work on.............

Port Jervis quadrangle, work in.......

Raritan quadrangle, work in..........

topographic work in ................... 31,32

Trenton folio, work on ................ 11

water investigations in .............. 56,59

New Mexico, El Paso quadrangle, work in.. 43, 45

Gallinas quadrangle, work in ......... 42, 44

geologic work in ................. 15, 16, 17

La Union quadrangle, work in ....... 43, 45

Las Cruces quadrangle, work in ....... 43,45

map of, preparation of ............... 53

topographic work in ............... 31 , $32,35-36,40,42,43-44,48,52$

water investigations in.............. 57,59

New York, Catatonk quadrangle, work in.. 11

cooperation with................... 35

Cooperstown quadrangle, work in..... $\quad 39$

gazetteer of ....................... 53

geologic work in .................... 11

allotment to ................... 9

Goshen quadrangle, work in......... 35-36,39

Greenwood Lake quadrangle, work in.. 11

Loon Lake quadrangle, work in..... 35-36, 39

Housatonic quadrangle, work in ...... 10

Port Jervis quadrangle, work in . . . . . 36,39

Potsdam quadrangle, work in...... $35-36,39$

Taconic quadrangle, work in.......... 10

topographic work in ............ 31,32,35-36

water investigations in ............ 55-56,59

Watkins Glen quadrangle, work in.... 11

Nickel, publication on.................. 18

Nomenclature, international system of.... 21

North America, map of, preparation of.... 21-22

North Carolina, Beckford quadrangle, work

in .......................... 36,39

cooperation with.................... 11, 36

Four Oaks quadrangle, work in . . ..... 36, 39

Gaffney quadrangle, work in...... $36,47,51$

geologic work in .................. 11

allotment to ...................... 9

Kings Mountain quadrangle, work in.. 36 ,

$39,47,51$

Nantahala folio, publication of........ 67

Pisgah folio, publication of............ 67

topographic work in....... $31,32,36,45,47,51$

water investigations in .............. 58

Winton quadrangle, work in .......... 36, 39

North Dakota, Ray quadrangle, work in... 36,39 topographic work in ............... $31,32,36$ water investigations in............... 57

O.

Ohio, Ashland quadrangle, work in ....... 36, 39 Athalia quadrangle, work in ......... 37,39

Bidwell quadrangle, work in . . ........ 36,39 Chillicothe quadrangle, work in....... 36,39
Page.

Ohio, Chagrin Falls quadrangle, work in... 39

Columbus Grove quadrangle, work in . . 36,39 cooperation with ................. 47

Deshler quadrangle, work in..... ...... 36,39

Flushing quadrangle, work in........ 13

geologic work in ................... 13

Glenwood quadrangle, work in....... 37,39

Kenova quadrangle, work in ......... 12

Middletown quadrangle, work in ... 36-37, 39

New London quadrangle, work in . .... . 37, 39

Point Pleasant quadrangle, work in. ... 37,39

Ravenna quadrangle, work in ........ 37,39

Ravenswood quadrangle, work in..... 37,39

St. Henry quadrangle, work in........ 37,39

topographic work in..... 31, 32, 36-37, 45, 47, 51

Warren quadrangle, work in.......... 39

Waverly quadrangle, work in......... 37,39

West Salem quadrangle, work in ...... 37,39

Wilkesville quadrangle, work in....... $\quad 39$

Youngstown quadrangle, work in ..... 37,39

Oil, study of ....................... 18-19

Oklahoma Agra quadrangle, work in ... 42-43, 44

Asher quadrangle, work in.......... 43, 45

cooperation with................... 42

Euchee Creek quadrangle, work in. ..... 42, 43

Fox quadrangle. work in ......... 42-43, 45

geologic work in, allotment to ......... 9

Luther quadrangle, work in......... 43, 44

Mallon quadrangle, work in.......... 44

Maud quadrangle, work in.......... 42-43, 45

Prague quadrangle, work in .......... 43, 45

Sac quadrangle, work in ........... 42-43, 45

Shawnee quadrangle, work in ...... 42-43, 45 topographic work in .. $31,40,42-43,48,49,50,52$

water investigations in ............... 57

See also Indian Territory.

Oregon, Blalock Island quadrangle, work in . $\quad 43$,

$\quad \mathbf{4 4 , 4 9}$

cooperation with ................. 43

geologie work in . . . . . . . . . . . . . . 18

allotment to.................... 9

Ironside Mountain quadrangle, work in. 43

Mount Hood Special quadrangle, work

in ...................... 43,49

Riddles quadrangle, work in......... 18

Roseberg quadrangle, work in ........ 18

topographic work in....... $31,40,43,48,49,52$

water investigations in .............. 57,59 Organization of Survey, outline of......... . 2-3

\section{$P$.}

Pacific coast, geologic work on............ 18

Paleontology, work in........... 12, 14, 19, 20-2

work in, allotments for .............. 1

Peat, work on ...................... 10

Pennsylvania, Amity folio, publication of. $\quad 67$ A rendtville quadrangle, work in....... 47

Bedford quadrangle, work in........... 47

Berks County, work in .............. 12

Chambersburg quadrangle, work in .... 12

Clarion quadrangle, work in ........ 12, 37,39 cooperation with................ 12,37, 47

Curwensville quadrangle, work in..... 12

Foxburg quadrangle, work in ......... $\quad 37$

geologic work in ................... 11, 12

allotment to.................... 9

Gettysburg quadrangle, work in...... 47 ' 7 
Pennsylvania, Houtzdale quadrangle, work

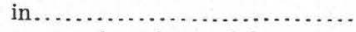

Page. Johnstown quadrangle, work in ....... 12,37 Lebanon County, work in ............ 12 Linesville quadrangle, work in........ 37, 39 Mercersburg quadrangle, work in..... 12 Middletown quadrangle, work in ...... 37,39 New Holland quadrangle, work in. ..... 37,39 Newville quadrangle, work in ......... 47 Port Jervis quadrangle, work in ...... 37,39 Punxsutawney quadrangle, work in.... 12 Rogersville folio, publication of........ 67 Sewickley quadrangle, work in . ..... 12, 37, 39 topographic work in....... 31,32,37,45, 47,51 Valier quadrangle, work in ......... 47 Warren quadrangle, work in ......... 37, 39 water investigations in . .............. 56,59

Phosphates, study of ................ 12,16-17 Photographic laboratory, work of......... 71

Publication branch, organization of ...... 2, 5-6 work of . ......................... 66-71

Publications of geologic branch, description

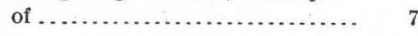

Q.

Quantity of water, investigations of..... 59-60 $\mathrm{R}$.

Reclamation service, separation of.

Reclamation work, value of water-resources data to........................

Resignations, embarrassment caused by ..

Rhode Island, cooperation with.

geologic work in ....................... topographic work in...

Rocky Mountain region, geologic work in. . 15-18

$$
\text { S. }
$$

San Francisco earthquake, study of.

Seismological Association, International, organization of ,............... Sierra Nevada, glaciation in, study of...... Silt, river transportation of, study of...... Smoke, abatement of, work on........... 63-64 South Carolina, Gaffney quadrangle, work

$$
\text { in ..................... } 36,47,51
$$

Kings Mountain quadrangle, work in 36 ,

$$
39,47,51
$$

Pisgah folio, publication of ............ 67 topographic work in .......... 31, 32, 36, 45, 47 South Dakota, topographic work in .31, 32, 40, 43, 51

Two Top quadrangle, work in ........ 43,44 water investigations in............. $\quad 57$ Wind Cave National Park, work in.... 44 States, cooperation of .................. 3-4 Steam-engineering section, work of ........ 62-63 Stream-flow measurement, importance of. progress of ..................... 55-58 Structural-materials division, work of .... 65-66 Suggestions, credit for

\section{T.}

Technologic branch, organization of...... 2,3,61

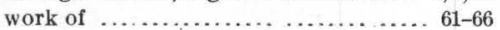

Tennessee, Ducktown Special quadrangle, work in .................. $37-39$ Franklin quadrangle, work in ....... 37-38, 47 geologic work in ................... 13 Jackson quadrangle, work in ......... 47 Nantahala folio, publication of ........ 67 Roan Mountain quadrangle, work in.. 13 topographic work in..... $31,32,37-38,45,47,51$ water investigations in .............. 59 Woodbury quadrangle, work in .. $37-38,39,47$ Tenth International Geological Congress, meeting of .................... 5

Texas, Atlanta quadrangle, work in....... 43 Boston quadrangle, work in.......... 43

Burnet quadrangle, work in........... 18

El Paso quadrangle, work in .......... 43

geologic work in ................... 16, 18 allotment to .................... 9

La Union quadrangle, work in ......... 43

Las Cruces quadrangle, work in ...... 43

Lindon quadrangle, work in........... 43

Llano quadrangle, work in............. 18

New Boston quadrangle, work in...... 44

San Marcos quadrangle, work in ....... 43

Texarkana quadrangle, work in ....... 43,44 topographic work in............. 31, 40, 43-44 water investigations in ............. 57,59

Texts, section of, work of............... $66-67$

Tin deposits, study of .................. 18

Topographic branch, organization of..... 2, 3,29

personnel of........................ 29

work of ............................ 30-54

Topographic maps, publication of ......... 68

Topographic surveys, condition of ........ 30-31

inspection of ....................... 52

Triangulation and computing, work in.... 45-52 Triangulation stations, establishment of... 30

Tungsten deposits, study of.............. 18

\section{U.}

\section{Underground-water investigations, prog-} * ress of .................... 58-59

United States, map of, preparation of...... 4

Utah, Browns Park quadrangle, work in... 44, 45 geologic work in ............... 15, 16-17, 18 allotment to .................... 9 land classification in.................. 15 map of, preparation of............... 53 Marsh Peak quadrangle, work in....... 44 Park City district, work in............ 17 topographic work in ............... 31, 40, 44 water investigations in ............ 57,59

\section{$\cdot \mathrm{V}$.}

Vanadium ores, study of

Vermont, Hanover quadrangle, work in.... 35,39 topographic work in........ $31,32,35,45,47,51$ Virginia, Buchanan quadrangle, work in... 47 Fincastle quadrangle, work in......... 47 Fort Monroe quadrangle, work in ..... 38, 39 geologic work in ................... 11,12 Hampton quadrangle, work in ........ 38,39 map of, preparation of............... $\quad 53$ 
Virginia, Natural Bridge quadrangle, work

in ....................... 38,39 topographic work in....... $31,32,38,45,47,51$ water investigations in 56,58

W.

Walcott, C. D., administration of ........... resignation of.

work of

Washery tests, progress of.

Washington, Blalock Island quadrangle,

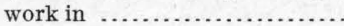

Colville Indian reservation, work in...

geologic work in .....................

Sumas quadrangle, work in............

topographic work in........ $31,40,44,48,49,52$

water investigations in .............. 57

Zillah quadrangle, work in ............ 44

Water, quality of, investigations of...... $59-60$

Water, underground, investigations of..... 59-60

Water resources branch, appropriation for, reduction of.

55

organization of ................. 2,3,54-55

work of ............................ $55-60$

Water-resources work, importance of....... 5

West Virginia, Athalia quadrangle, work in. 38,39 cooperation with ..................... 38

Elkins quadrangle, work in.......... 47

geologic work in .................... 12

allotment to .................... 9

Glenwood quadrangle, work in ....... 38,39

Kenner quadrangle, work in........... 38,39

Kenover quadrangle, work in.......... 11

map of, preparation of................. 53

Nicholas quadrangle, work in ......... $\quad 12$

Otter quadrangle, work in............. 38,39

Parsons quadrangle, work in .......... 38,39
West Virginia, Point Pleasant quadrangle,

work in ....................... 38,39

Ravenswood quadrangle, work in ..... 38,39 topographic work in........ $31,32,38,45,47,51$ Walton quadrangle, work in.......... 38,39 water investigations in .............. 56

Winfield quadrangle, work in......... 38,39

Wisconsin, cooperation of ............... 56-57

Cross Plains quadrangle, work in...... 38,39

geologic work in ...................... 14

Lancaster-Mineral Point folio, publica-

tion of .......................

Milwaukee Special folio, publication of. 67

Oconomowoc quadrangle, work in..... $\quad 38$

Sparta quadrangle, work in........... 38, 39

topographic work in .............. $31,32,33,38$

water investigations in ............. 56-57

Waukegan quadrangle, work in........ 33

Winona quadrangle, work in .......... 38

Wyoming, Bald Mountain-Dayton folio, publication of................ 67

Cloud Peak-Fort McKinney folio, publication of .

Devils Tower folio, publication of ...... $\quad 67$

Fremont Peak quadrangle, work in.... 44 geologic work in ...................... 15, 17

allotment to...................... 9

map of, preparation of............... $\quad 53$

Medicine Bow quadrangle, work in..... 44 topographie work in........... 31, 40,44,52

water investigations in $\ldots \ldots \ldots \ldots \ldots$

\section{$\mathrm{Y}$.}

Yellowstone National Park, work in........

18

Z.

Zine, study of.

28 